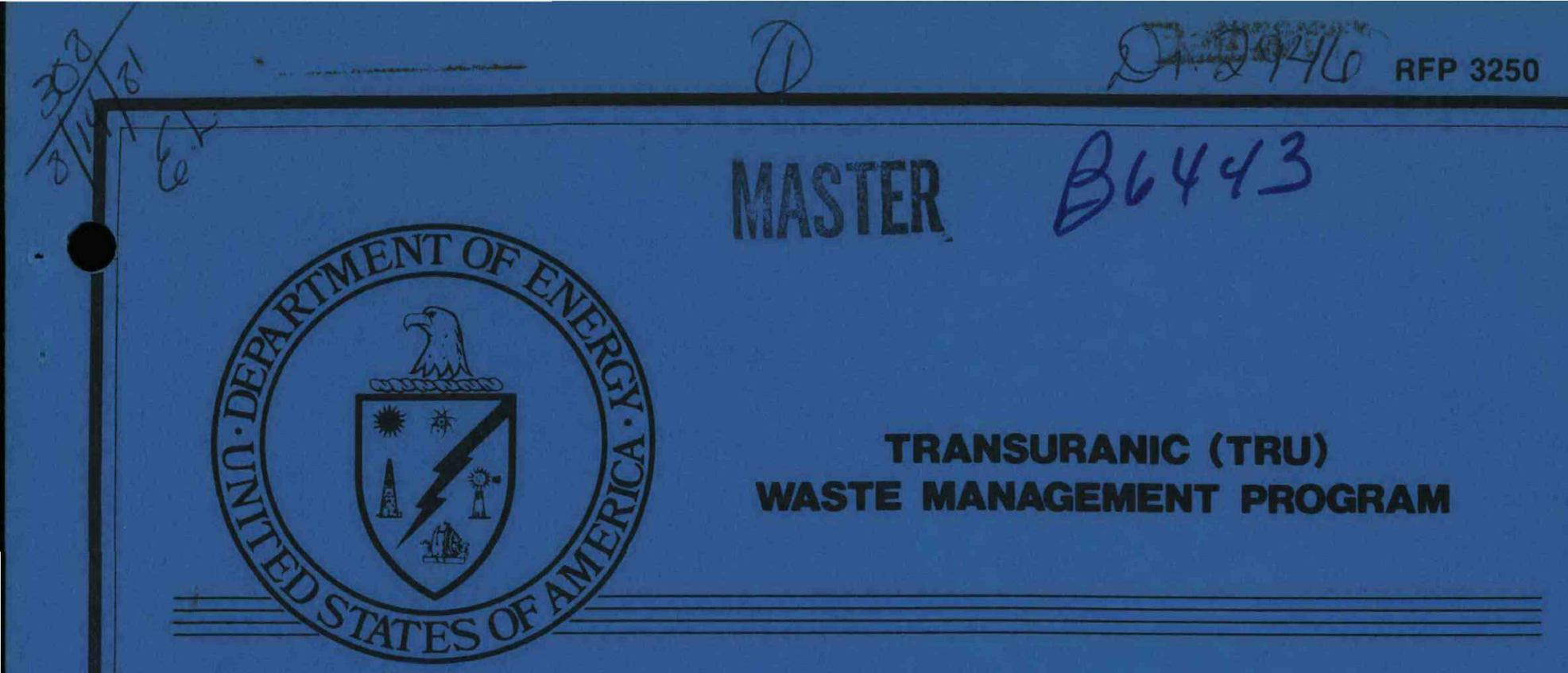

\title{
Nuclear Waste Incineration Technology Status
}

July 1981

Rockwell International ENERGY SYSTEMS GROUP ROCKY FLATS PLANT 


\section{DISCLAIMER}

This report was prepared as an account of work sponsored by an agency of the United States Government. Neither the United States Government nor any agency Thereof, nor any of their employees, makes any warranty, express or implied, or assumes any legal liability or responsibility for the accuracy, completeness, or usefulness of any information, apparatus, product, or process disclosed, or represents that its use would not infringe privately owned rights. Reference herein to any specific commercial product, process, or service by trade name, trademark, manufacturer, or otherwise does not necessarily constitute or imply its endorsement, recommendation, or favoring by the United States Government or any agency thereof. The views and opinions of authors expressed herein do not necessarily state or reflect those of the United States Government or any agency thereof. 


\section{DISCLAIMER}

Portions of this document may be illegible in electronic image products. Images are produced from the best available original document. 
This report was prepared as an account of work sponsored by an agency of the United States Govermment. Neither the United States Government nor any agency thereof, nor any of their employees, makes any warranty, express or implied, or assumes any legal liability or responsibility for the accuracy, completeness, or usefulness of any information, apparatus, product, or process disclosed, or represents that its use would not infringe privately owned rights. Reference herein to any specific commercial product, process, or service by trade name, trademark, manufacturer, or otherwise, does not necessarily constitute or imply its endorsement, recommendation, or favoring by the United States Government or any agency thereof. The views and opinions of authors expressed herein do not necessarily state or reflect those of the United States Government or any agency thereof.

Printed in the United States of America Available from the

National Technical Information Service

U.S. Department of Commerce

Springfield, Virginia 22161

Page Range

Domestic Price*

001-025

026-050

$\$ 5.00$

051-075

6.00

076-100

7.00

8.00

*All microfiche are priced at $\$ 3.50$

Prices Subject to Change Without Notice 
RFP -3250

UC -70

\section{NUCLEAR WASTE INCINERATION \\ TECHNOLOGY STATUS}

D. L. Ziegler

G. D. Lehmkuh1

L. J. Meile

This book wes oreodred as an account of work sponsored by ar agency of the United States Government Nerther the Unil ed States Government nor any agency therest nor any of their employees makes any campleteness or usefuntiess of any irformation apparatus product or process disclosed or represents that 's ise would not infringe ur vately owned rights Reference herein to any specific ammercial wroduct brocess or serv ce by trade name trademiark Indinutatturer or otherwise does States Government or ary agency thereg't The vews and opinions of authors expressed heren do not

\section{Rockwell International \\ Energy Systems Group \\ Rocky Flats Plant \\ Golden, Colorado 80401}

$$
\text { July 15, } 1981
$$

Prepared by

Transuranic Waste Systems office

for

TRANSURANIC (TRU) WASTE MANAGEMENT PROGRAM

UNITED STATED DEPARTMENT OF ENERGY

Under Contract DE-ACO4-76DP03533 


\section{ACKNOWLEDGEMENTS}

The authors wish to gratefully acknowledge the use of unpublished incineration information from K. Y. Gallagher and incinerator information compiled by S. P. Sontag.

(a) 
The incinerators developed and/or used for radioactive waste combustion are discussed and suggestions are made for uses of incineration in radioactive waste inanagement programs and for incinerators best suited for specific applications. Information on the amounts and types of radioactive wastes are included to indicate the scope of combustible wastes being generated and in existence. An analysis of recently developed radwaste incinerators is given to help those interested in choosing incinerators for specific applications. Operating information on U.S. and foreign incinerators is al so included to provide additional background information. Development needs are identified for extending incinerator. applications and for establishing commercial acceptance. 


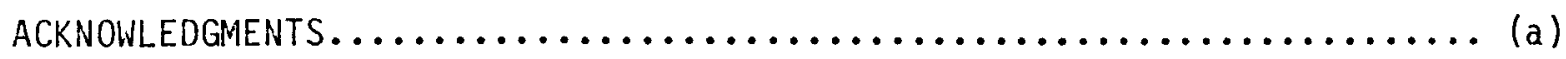

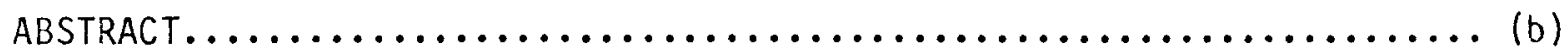

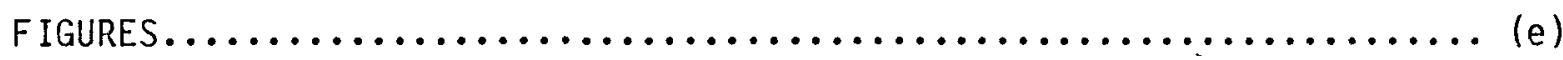

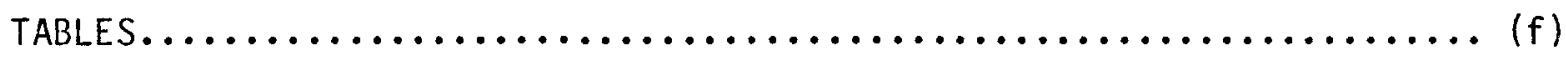

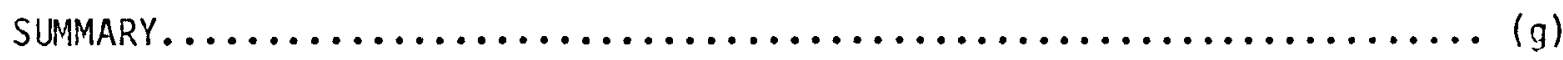

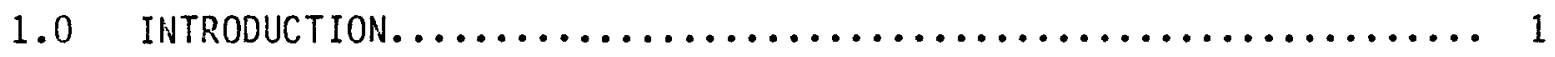

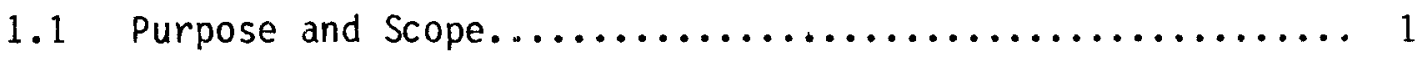

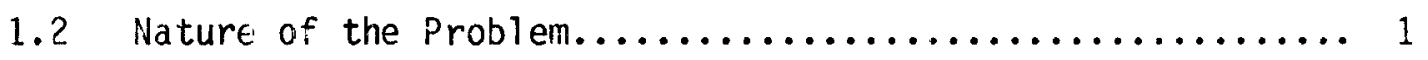

2.0 WASTE CATEGORIZATION AND QUANTITIES $\ldots \ldots \ldots \ldots \ldots \ldots \ldots \ldots \ldots$

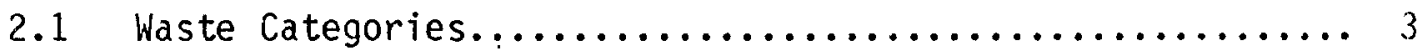

2.2 Waste Inventories and Storage Capabilities............ 5

2.2.1 Existing Inventory.................... 5

2.2.1.1 DOE Buried Wastes, TRU and LLW........ 6

2.2.1.2 DOE Wastes 1970 to $1980 \ldots \ldots \ldots \ldots \ldots \ldots 7$

2.2.1.3 Wastes at Commercial Sites to $1980 \ldots \ldots .7$

2.2.2 Projections of Future Inventory............ 8

2.2.3 Capacities and Effect of Incineration........... 14

(c) 


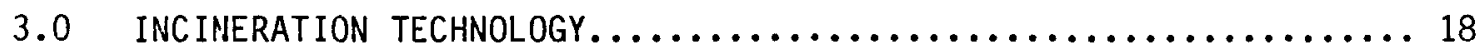

3.1 Background.................................. 18

3.2 Previous Experience............................. 19

3.2.1 Benefits and Problems...................... 20

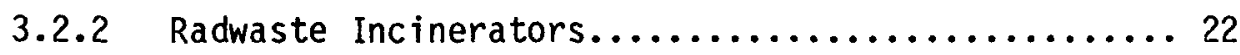

3.3 Characteristics and Capabilities of Recently Developed

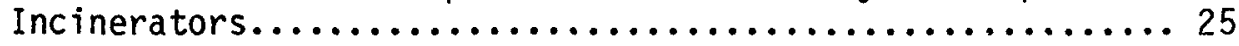

3.3.1 Acid Digestion (HEDL) ...................... 27

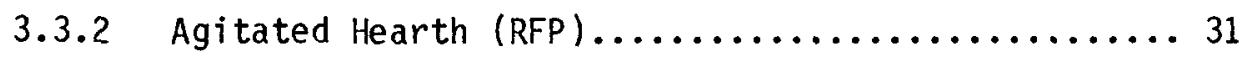

3.3.3 Controlled Air (LANL) ................... 34

3.3.4 Cyclone Drum (MF)........................ 38

3.3.5 Electric Controlled Air (SRL) ..............43

3.3 .6 Fluidized Bed (RFP) ................... 46

3.3.7 Molten Salt (RI) ...................... 50

3.3 .8 Rotary Kiln (RFP)...................... 54

3.3.9 Slagging Pyrolysis (INEL) $\ldots \ldots \ldots \ldots \ldots \ldots \ldots \ldots$

3.4 Incineration Cost Evaluations.................... 62

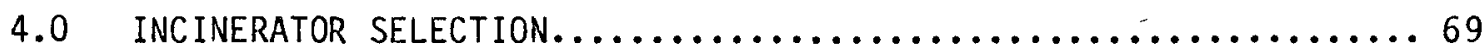

4.1 Selection Criteria............................69

4.2 Suggested Incinerators for Radwaste Applications......... 75

4.2.1 TRU Waste Applications........................ 78

4.2.1.1 Transuranic Recovery.............. 78

4.2.1.2 Transuranic Immobilization........... 82

4.2.1.3 Reduced Volume and Gas Generation....... 85 


\section{CONTENTS (Continued)}

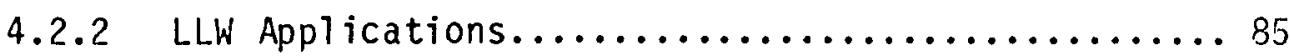

4.2.2.1 LLW from Power Plant Operations........ 35

4.2.2.2 Burial Site LLW................. 87

4.2.2.3 Institutional and Medical Wastes.......87

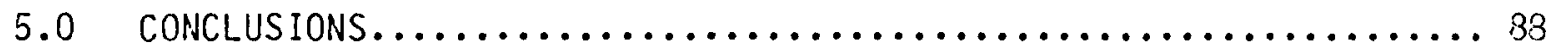

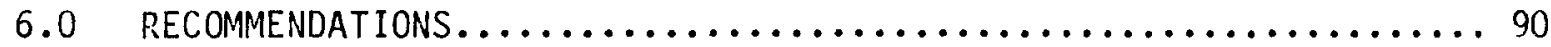

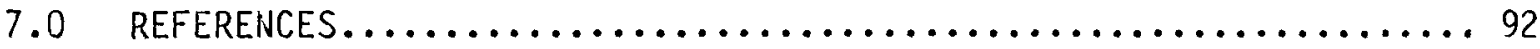

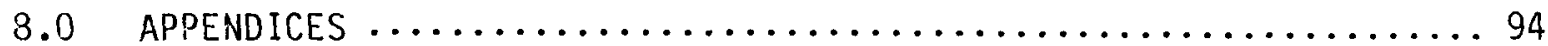

Appendix A - Early United States Radioactive

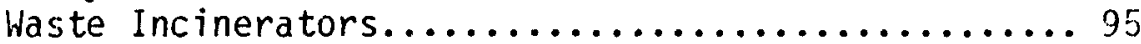

Appendix B - Recent United States Radioactive Waste Incinerators........................ 99

Appendix C - Foreign Radioactive Waste

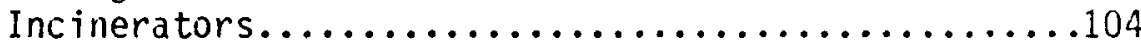

\section{FIGURES}

2-1 Inventory of TRU waste at DOE sites....................

2-2 Inventory of $L L W$ at DOE sites..........................

2-3 Projected volumes of stored commercial TRU waste............. 12

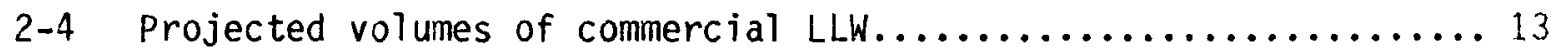

2-5 Effect of incinerating DOE TRU wastes..................... 16

3-1 Capitol investment per unit capacity for installed combustion system in 1979 dollars.................................. 66

-3-2 Installed cost of each combustion system estimated for a capacity of $45 \mathrm{~kg} / \mathrm{hr} \ldots \ldots \ldots \ldots \ldots \ldots \ldots \ldots \ldots \ldots \ldots \ldots . \ldots \ldots$

4-1 TRU waste incineration selection matrix................. 76

4-2 Low level waste incineration selection matrix..............77 


\section{TABLES}

Page

2-1 Estimated buried TRU waste volume at major DOE sites......... 6

2-2 Estimated buried LLW volume at DOE sites................. 6

2-3 Retrievably stored TRU waste at major DOE sites............ 7

2-4 Estimated waste at commercial burial sites as of January 1, $1980 \ldots \ldots \ldots \ldots \ldots \ldots \ldots \ldots \ldots \ldots \ldots \ldots \ldots \ldots \ldots \ldots . \ldots . \ldots$

2-5 Projected annual DOE TRU waste generation................ 9

2-6 Projected annual DOE LLW generation.................... 9

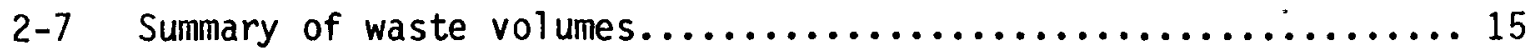

2-8 Retrievable storage capacity for TRU wastes $(1980) \ldots \ldots \ldots \ldots \ldots 17$

3-1 Process characteristics of recently developed TRU

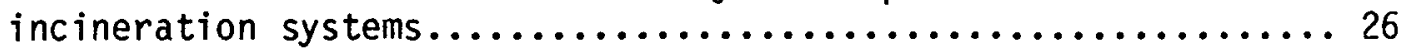

3-2 Installed incineration capacity and associated costs in

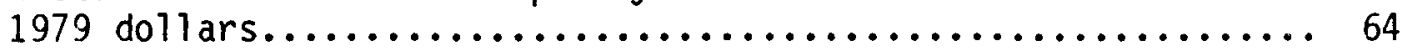


SUMMARY

The Transuranic Waste Systems Office (TWSO) at Rocky Flats has the responsibility of providing assistance to DOE in coordinating development of technology for management of transuranic waste. The objective of this report is to provide a technical assessment of the status of radwaste incineration and define areas where additional technology development may be required.

In the past, incineration has been used both to reduce the waste volume and to convert combustible material to an ash which can be processed for actinide recovery. Two incinerators; one at LANL and one at Rocky. Flats, have each operated for about 25 years in plutonium recovery operations. Many of the early incineration systems required extensive modification to improve performance or to achieve operational status. Information on the incinerators installed for radwaste use in the U.S. and foreign countries is provided in the appendices of this report. While some of these systems provided a valuable function and burned large volumes of waste, operation of many of the units was terminated because of operational problems and high maintenance requirements. Identification of the problems led to an extensive incinerator development and demonstration effort within DOE during the last decade.

This report includes a discussion of the need for radwaste incineration, the status of demonstration of the more recently developed combustion systems, an assessment of the incinerators for specific types of waste or areas of application, and identification of additional development needs.

A listing of the amounts of waste presently in storage and estimates of waste generation for the next 20 years for both defense operations and the commercial nuclear industry is presented in Selection 2.0, Waste Categorization and Quantities. For DOE, the presently available burial and storage capacity exceeds the projected accumulated volumes of TRU and LLW waste through the year 2000. However, two sites, LANL and ORNL, will have 
generated more TRU waste volume than the retrievable storage capabilities presently available at those sites. The projected commercial waste volume generated by the year $2000\left(4,800,000 \mathrm{~m}^{3}\right)$, will exceed the presently available storage capacity $\left(3,647,000 \mathrm{~m}^{3}\right)$. Recent political actions and actions by some burial site operators may further reduce burial capacity and cause increased interest in incineration of these wastes. Other factors which will have an impact on the need for incineration of radwaste are increased costs of transportation and storage and the need to reduce hazards associated with transportation and storage of combustible materials.

The use of incineration in radwaste applications is somewhat more restrictive than a typical commercially available combustion system for municipal waste. Factors such as radiation protection for operators and maintenance personnel, containment of radioactive materials and nuclear criticality protection result in a more complex system design. Nine of the combustion systems recently developed for radwaste in the U.S. are discussed in Section 3.0, Incineration Technology. The nine systems are as follows:

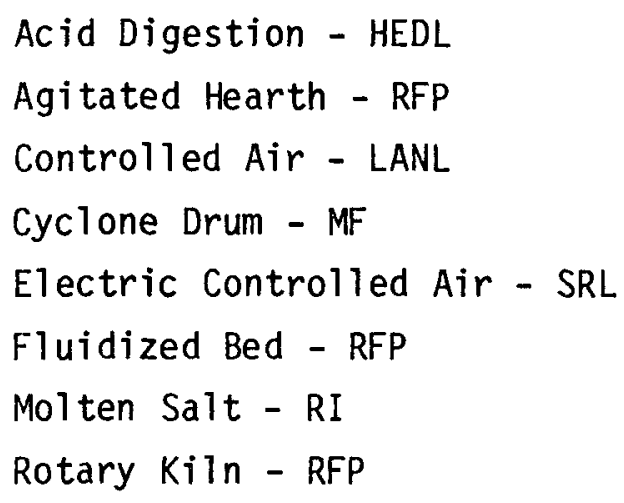

While most of these units have undergone pilot and/or demonstration scale testing with suspect radwaste, three units; Agitated Hearth, Rotary $\mathrm{Kiln}$, and Slagging Pyrolysis, have been designed for production operations based on information from the non-nuclear industrial applications. Each of the nine incineration systems were chosen for development or application 
because they offered solutions to incineration problems at specific sites and appeared to be well suited in general for nuclear applications. The Acid Digestion unit, Electric Controlled Air, and Fluidized Bed Incinerators were specifically developed to accommodate high levels of fissile material. In selecting the Slagging Pyrolysis unit, the ability to accommodate unsorted waste with high concentrations of noncombustible was an important consideration. The use of commercially available incineration technology was important in selection of the Controlled Air and Agitated Hearth Incinerators. A low capital investment was a major objective of the Cycione Drum Incinerator and in situ neutralization of acid gases was important to selection of the Molten Salt and Fluidized Bed systems. The operating characteristics of each of these systems is summarized in Table 3-1. The solid waste capacities of these systems vary from a low of $5 \mathrm{~kg} / \mathrm{hr}$ for the Electric Controlled Air to a high of $850 \mathrm{~kg} / \mathrm{hr}$ for the Slagging Pyrolysis. Some of the units have also been demonstrated suitable for combustible liquid processing. Although most of these systems have undergone extensive TRU waste testing with various feed components, there are two areas in need of additional development activity if they are to be used for incineration of wastes with $B-\gamma$ activity. The ability of the offgas treatment systems to remove fission products will need to be demonstrated. Also remote operation and maintenance of the incinerator will have to be demonstrated if the system is to be used with high levels of $B-\gamma$ activity.

A commercialization program for the Controlled Air Incinerator has been initiated which will include evaluation of fission product removal in the offgas system. Complete remote operation and maintenance has not been demonstrated for any of the nine combustion systems.

When an incineration system is being selected for a given application, the first considerations are that the unit can safely process the waste components at the desired capacity and produce the desired objectives of volume reduction and product form. The installed capital cost and the cost of operation and maintenance are secondary factors which can be used as 
selection criteria among the systems which are technically suitable for a given application.

Capital cost information was obtained for each of the systems as installed (or projected installations). These costs were adjusted to 1979 dollars and are presented in Table 3-2. Some caution should be used with these estimates because considerable differences exist in the degree of instrumentation, nuclear criticality control and support equipment or facilities included in the cost figures. To obtain a more direct comparison of capital cost, each system was also estimated for a $45-\mathrm{kg} / \mathrm{hr}$ capacity using the 0.6 power rule. The installed capital cost for $45-\mathrm{kg} / \mathrm{hr}$ capacity varied from a low of $\$ 1,100,000$ for the Cyclone Drum Incinerator to a high of $\$ 10,100,000$ for the Electrical Controlled Air Incinerator. Selection of incinerators best suited for specific wastes and waste type is discussed in Section 4.0, Incinerator Selection.

Each of the nine combustion systems has been identified as a preferred candidate for one or more specific applications. Presented in Figure 4-1 and 4-2 is the waste incineration selection matrix for TRU and LLW respectively. For each site and waste specific application, one or more incineration systems have been identified as suitable candidates. Factors used in identifying preferred candidates were the waste component composition, activity level, fissile material content, capital cost, desired capacity, and final product form. Information on operating and maintenance cost for the systems were not available for this report and could become major factors in selection of a process for a specific site.

The incineration technology appears to be well developed for most of the TRU applications. Further development for TRU waste should be undertaken only for well defined specific needs. Commercialization of the technology is needed and is expected to require some experimental testing or demonstration in addition to a considerable amount of consulting and .design review work. This is presently being pursued for the Controlled Air 
Incineration system and may be needed for other systems. An effort should be made to obtain and document the nuclear safety and operating information on the systems suitable for higher levels of fissile material content waste. 


\subsection{INTRODUCTION}

\subsection{Purpose and Scope}

Nuclear operations of all kinds produce a variety of wastes. These wastes have been principally managed either by disposing of them in shallow land burial or by placing them into interim storage awaiting further processing and/or disposal. A significant portion of these wastes are combustible, ranging, on the average, from 25 to 50 volume percent, depending on the operation. Incineration of these combustibles could be of benefit to nuclear waste management. This report examines the status of incineration technology within the Department of Energy (DOE) for treating combustible nuclear wastes. Waste incineration processes are described briefly along with a summary of current development status and potential applications. Existing and projected future nuclear waste volumes are discussed along with a discussion of the impact that incineration could have in reducing these waste volumes.

\subsection{Nature of the Problem}

Nuclear wastes are categorized and classified in a number of ways. The most common system has three principal categories; high level waste (HLW), low level waste (LLW), and transuranic waste (TRU). High level waste results from processing of irradiated reactor fuel. It is, by definition, the raffinate waste from the first cycle of fuel reprocessing. It contains the vast majority of the fission products in the fuel and a small amount of transuranic elements. However, the TRU content is high enough that the waste should be isolated from mans environment for a long period of time. High level waste exists either as liquids or solidified sludges and salt cakes, and is not a combustible waste stream. All combustible wastes fall into the LLW or TRU category. Transuranic wastes are defined as waste materials contaminated with transuranic elements or .${ }^{233} \mathrm{U}$ in amount producing $10 \mathrm{nci} / \mathrm{gm}$ or more of alpha activity. The remainder of the wastes are classified as LLW. 
Long-term management plans call for HLW and TRU to be isolated from the biosphere in mined geologic repositories. These wastes are currently held in interim storage. Complete specifications for TRU waste forms acceptable for such geologic isolation are not yet available. Preliminary specifications suggest that over a given percentage of combustibles may not be acceptable and that wastes may have to be chemically inert. The ash resulting from incineration can be readily converted into very inert forms. These potential requirements provide the major impetus to development of incineration technology for TRU wastes. Additional benefits of incineration of TRU wastes include large volume reduction factors and elimination of fire and gas generation potential.

Low level waste is managed by disposal in shallow land burial. Low level waste with high specific activity is also being placed in intermediate depth storage (approximately $50 \mathrm{~m}$ ). This is a satisfactory management method for low level waste including combustibles, but the availability of burial space, especially for wastes from commercial and institutional sources, is rapdily diminishing. The volume reduction provided by incineration of combustible LLW would greatly ease this capacity problem. 


\subsection{Waste Categories}

Wastes contaminated with radioactivity have been classified into many categories in the past with the results generally reflecting the primary interest of the persons or agency making the classification. Some of the historical categorizations are:

1) DOE and commercial;

2) newly generated, stored, and buried;

3) TRU and LLW;

4) contact handled and remote handled, reflecting beta-gamma activity;

5) combustible and non-combustible; and

6) material content, such as paper, rags, or plastics.

Each of these categories can be further subdivided as follows:

\section{A. Source of Generation}

1. DOE

Weapons Production

Energy Research

2. Commercial

Power Generation

Fuel Fabrication

Research and Industrial Applications

3. Institutional

Hospitals

Universities 
B. Time of Generation

1. Present Generation

2. Future Generation

3. Stored-Retrievable

4. Buried

C. Alpha Activity

1. TRU ( $>10 \mathrm{nCi} /$ gram activity from TRU elements)

High Fissile Content (glove box generated waste)

Low Fissile Content (non-glove box generated waste)

2. $\operatorname{LLW}(<10 \mathrm{nC} \mathrm{i} / \mathrm{gram})$

D. Beta-Gamma Activity

1. Contact Handled ( $<200 \mathrm{mR} / \mathrm{hr}$ surface radiation)

2. Remote Handled ( $>200 \mathrm{mR} / \mathrm{hr}$ surface radiation)

E. Material Content

1. Paper

2. PVC Plastic

3. Other Plastic

4. Rubber

5. Wood

6. Organic Resins

7. Filters

Cartridge

HEPA

8. Leaded gloves

9. Organic Liquids 
10. Carbon

Graphite

Filter Media

11. Cloth

12. Leather

13. Biological Wastes

14. Scintillation Vials

\subsection{Waste Inventories and Storage Capabilities}

To evaluate the volume of nuclear waste available for processing, one has to consider the amount that presently exists in storage, the amount currently being generated, and finally estimating the arnount that will be generated in the future. Each of these categories will be discussed in the following sections of this report.

\subsubsection{Existing Inventory}

Combustible waste generated from the early atomic energy research, development, and production operation were placed in ground burial. In 1970, the transuranic contaminated wastes were placed in retrievable storage, and in the future the transuranic waste will be placed in a permanent repository. As the waste storage methods become more sophisticated, waste volume reduction methods become more attractive. However, each of these storage conditions, as well as the present generation of defense and commercial waste, represent considerably different processing requirements. For example, aithough INEL has several times the volume of stored TRU waste relative to SRP, the waste at SRP contains twice the number of curies that are stored at INEL. 


\subsubsection{DOE Buried Wastes, TRU, and LLW}

In 1970, the AEC (nOW DOE) initiated a new policy directing that newly generated TRU wastes be segregated and stored so that they could be retrieved intact and in an uncontaminated condition for at least 20 years. Prior to this policy, TRU waste and LLW were routinely placed in shallow 1 and burial. The volumes of buried TRU waste at major DOE sites are shown in Table 2-1. Volumes of LLW buried at major DOE sites are shown in Table 2-2. Records of waste burial are not as precise as those for storage, and hence the uncertainties are much higher. The volumes shown are best estimates of the initially buried waste volume. They do not

\section{TABLE 2-1 ESTIMATED BURIED TRU WASTE VOLUME AT MAJOR DOE SITES}

\begin{tabular}{lr}
\hline \multicolumn{1}{c}{ Site } & Volume \\
\hline Buried & $\mathrm{m}^{3}$ \\
\hline Hanford Site & 225,000 \\
Idaho National Engineering Laboratory (INEL) & 57,000 \\
LoS Al amos National Laboratory (LANL) & 11,500 \\
Nevada Test Si te (NTS) & 5,700 \\
Oak Ridge National Laboratory (ORNL) & 6,300 \\
Pantex Plant & 30 \\
Sandia National Laboratories (SNL) & 10 \\
Savannah River Plant (SRP) & 27,000 \\
$\quad$ Estimated Total Buried TRU Waste: & $330,000 \mathrm{~m}^{3}$ \\
\hline
\end{tabular}

*Excludes about 11 million $\mathrm{m}^{3}$ of TRU and Fission Product contaminated soils resulting from liquid waste disposal, containing over $200 \mathrm{~kg}$ of $\mathrm{Pu}$ (mostly Hanford). In addition, there are about 3 million $\mathrm{m}^{3}$ of contaminated soils resulting from accidental discharges of spills; the amount of this soil that is contaminated with over $10 \mathrm{nCi} / \mathrm{g}$ of transuranics is under investigation.

TABLE 2-2 ESTIMATED BURIED LLW VOLUME AT DOE SITES

\begin{tabular}{lr}
\hline \multicolumn{1}{c}{ Site } & $\begin{array}{r}\text { Volume Buried } \\
\text { Prior to } \\
\mathrm{m}^{3}\end{array}$ \\
\hline Hanford Site & 80 \\
INEL & 464,800 \\
LANL & 117,000 \\
NTS & 115,300 \\
ORNL & 57,020 \\
SNL & 192,000 \\
SRP & 1,336 \\
Others & 336,500 \\
\multicolumn{1}{c}{ Total } & 436,900 \\
\hline
\end{tabular}


include any soil contaminated through the rupture or corrosion of containers in the ground, which is estimated to be approximately 1.4 times the initial buried waste volume. Exhumation would likely require repackaging, which would affect volume and handling requirements.

\subsubsection{DOE Wastes 1970 to 1980}

Table 2-3 gives the inventories of contact handled and remotely handled TRU waste held in retrievable storage at major DOE sites. In addition, there are usually small quantities in staging areas at various other site awaiting shipment to one of the major storage sites.

TABLE 2-3 RETRIEVABLY STORED TRU WASTE AT MAJOR DOE SITES

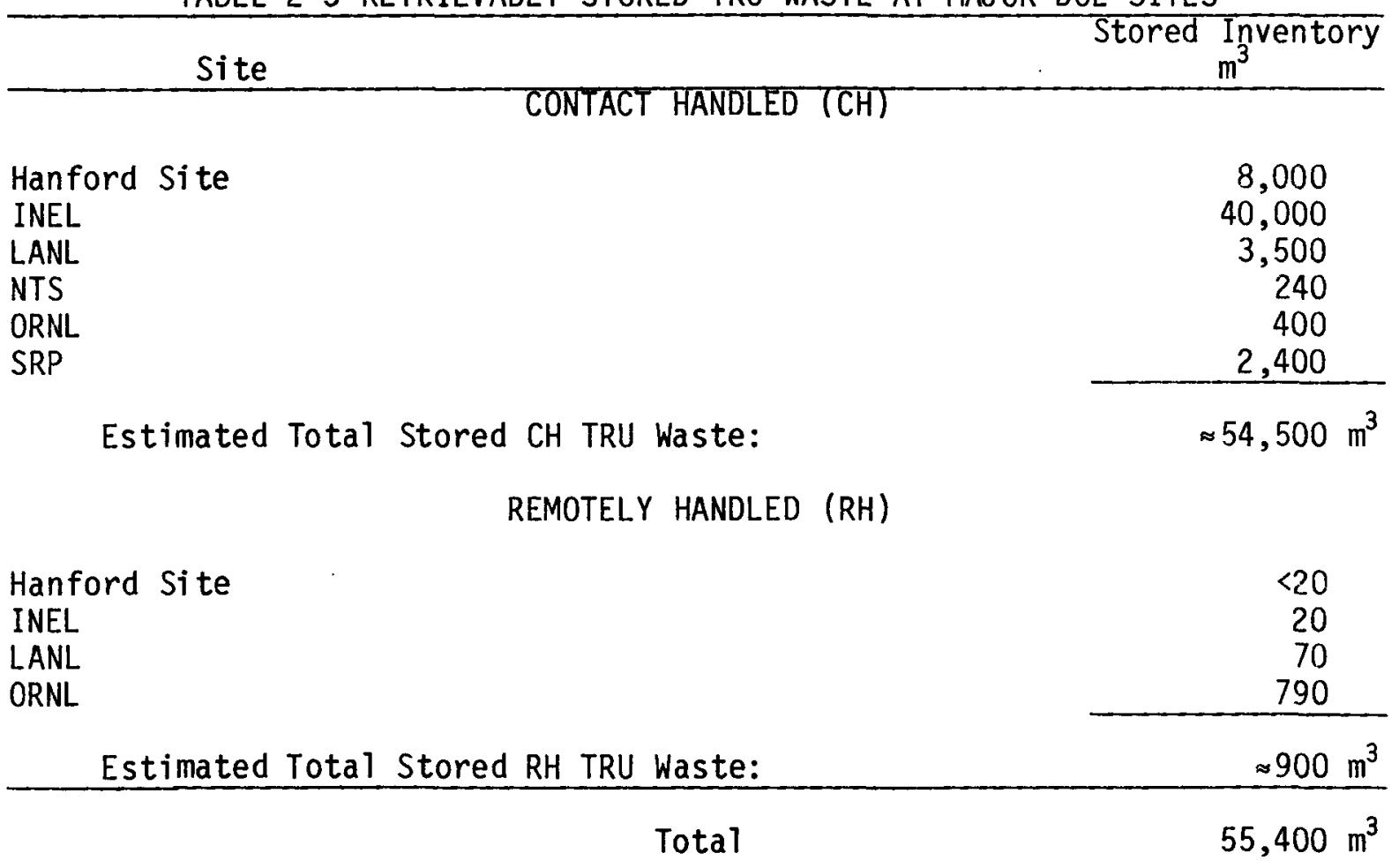

\subsubsection{Waste at Commercial Sites to 1980}

DOE facilities and commercial TRU waste generators have shipped wastes . to five of the six commercial waste disposal sites in the United States. (Barnwel1, South Carolina, has always prohibited the burial of TRU waste.) 
In the past, no regulation required separation of TRU waste from the other wastes buried at the commercial sites. However, the TRU content and the total volume of the buried waste is known. The TRU content ranges from $3.6 \mathrm{~kg}$ at West Valley, New York, to $69.1 \mathrm{~kg}$ at Maxey Flats, Kentucky. Of the $668,000 \mathrm{~m}^{3}$ of buried waste, $363,000 \mathrm{~m}^{3}$ is suspected to contain transuranics and only $20 \%$ of this volume is expected to contain greater than $10 \mathrm{nCi} / \mathrm{g}$ TRU. Since February 1980, there has been no commercial site licensed to receive TRU waste for burial.

Table 2-4 1ists the commercial disposal sites, volumes of buried waste, volumes of wastes which may contain TRU, and Mass of TRU elements present.

TABLE 2-4 ESTIMATED WASTE AT COMMERCIAL BURIAL SITES AS OF JANUARY 1,1980

\begin{tabular}{|c|c|c|c|}
\hline Site & $\begin{array}{c}\text { Buried Volume } \\
\text { Total } \mathrm{m}^{3} \\
\end{array}$ & $\begin{array}{c}\text { Suspect TRU } \\
\mathrm{m}^{3}\end{array}$ & $\begin{array}{c}\text { Mass of TRU } \\
\text { El ements } \\
\mathrm{kg}\end{array}$ \\
\hline $\begin{array}{l}\text { Barnwell, South Carolina } \\
\text { Beatty, Nevada } \\
\text { Maxey Flats, Kentucky } \\
\text { Richland, Washington } \\
\text { Sheffield, Ill inois } \\
\text { West Valley, New York }\end{array}$ & $\begin{array}{r}269,300 \\
73,898 \\
135,287 \\
35,844 \\
86,701 \\
66,521 \\
\end{array}$ & $\begin{array}{c}0 \\
58,054 \\
135,287 \\
16,238 \\
86,701 \\
66,521 \\
\end{array}$ & $\begin{array}{l}0 \\
14.3 \\
69.1 \\
23 \\
13.4 \\
3.6 \\
\end{array}$ \\
\hline Total & 667,551 & 362,801 & 123.4 \\
\hline
\end{tabular}

\subsubsection{Projections of Future Inventory ${ }^{1}$}

Table 2-5 and 2-6 give the projected rates of TRU waste and LLW generation respectively at DOE facilities in the next 20 years, based on scheduled operations, research, and facilities decontamination. Uncertainties are large, because of the difficulty in projecting both weapons production schedules and research activities very far into the future. Furthermore, even when trends are correctly forecast, the amounts generated in any single year can vary greatly from the average because of the startup - or completion of research projects, the decontamination of equipment or facilities, and accidents that may generate TRU waste. 


\begin{tabular}{|c|c|}
\hline 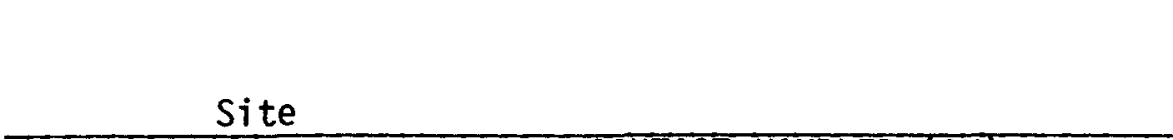 & $\begin{array}{l}\text { Average Generation } \\
\text { Rate } 1980-2000 \\
\left(\mathrm{~m}^{3} / \mathrm{yr}\right)\end{array}$ \\
\hline \multicolumn{2}{|l|}{ CONTACT HANDLED (CH) } \\
\hline $\begin{array}{l}\text { Argonne National Laboratory (ANL)-East } \\
\text { Battelle, Columbus Laboratories (Battelle-C) } \\
\text { Bettis Atomic Power Laboratory (Bettis) } \\
\text { Hanford Site } \\
\text { INEL } \\
\text { LANL } \\
\text { Lawrence Livermore National Laboratory (LLNL) } \\
\text { Lovelace Biomedical and Environmental Research Institute } \\
\text { Mound Facility (MF) } \\
\text { ORNL } \\
\text { Paducah Gaseous Diffusion Plant } \\
\text { Rocky Flats Plant (RFP) } \\
\text { SNL } \\
\text { SRP and Laboratory }\end{array}$ & $\begin{array}{r}180 \\
40 \\
<10 \\
470 \\
110 \\
550 \\
25 \\
<1 \\
560 \\
70 \\
1 \\
1,700 \\
5 \\
150\end{array}$ \\
\hline $\begin{array}{l}\text { Projected Annual CH TRU Waste Generation: } \\
\text { REMOTELY HANDLED (RH) }\end{array}$ & $\approx 3,900$ \\
\hline $\begin{array}{l}\text { ANL-East } \\
\text { Hanford Site } \\
\text { INEL } \\
\text { LANL } \\
\text { ORNL } \\
\text { SNL }\end{array}$ & $\begin{array}{r}10 \\
<740 \\
5 \\
10 \\
75 \\
3 \\
\end{array}$ \\
\hline Projected Annual RH TRU Waste Generation: & $\approx 800$ \\
\hline Projected Total Annual DOE TRU Waste Generation: & $\approx 4,700 \mathrm{~m}^{3}$ \\
\hline
\end{tabular}

TABLE 2-6 PROJECTED ANNUAL DOE LLW GENERATION

DOE Field Office

Average Generation

Rate $1980-2000$

Albuquerque

$\mathrm{m}^{3} / \mathrm{yr}$

San Francisco

15,520

Chicago

4,030

Idaho

2,450

Nevada

4,750

Oak Ridge

Pittsburgh N.R.

- Richl and

1,360

7,990

2,450

Savannah River

12,940

Schenectady N.R.

16,110

1,700

Total

69,300 
Figures 2-1 and 2-2 show the existing inventory of DOE TRU waste and LLW respectively, and the inventory projected to accumulate between now and the year 2000, assuming that current, or similar, management practices continue to that time. The horizontal line represents the buried waste; the sloping line shows the growth in total inventory from increases in waste. When a permanent repository becomes available, the inventory of stored TRU waste will cease growing and will gradually diminish. The volume of buried waste would be reduced if exhumation began at any of the sites. The total volume could be further reduced by processing the waste. The bulk of the remotely handled TRU waste volume projected for the next 20 years will be generated by the Fast Flux Test Facility (FFTF) at Hanford, Washington.

At the present time, DOE has authority and responsibilities only for the management of government generated wastes and to provide generic support to commercial waste management technology. In the future, it is possible that commercial waste may have to be managed by the DOE. In this event, commercial waste would be handled in the same manner as DOE waste. Should spent fuel be reprocessed, the volume of waste to be managed will depend on the number and the capacity of commercial nuclear power plants. Several fuel cycles and a wide range of nuclear power capacities are possible. The once-through uranium cycle, whch is now used in U.S. commercial power reactors, requires no spent fuel reprocessing, and therefore, minimizes waste generation. The uranium recycle and the uranium-plutonium recycle fuel cycles do involve reprocessing and generate TRU waste and LLW.

The NRC is likely to require permanent isolation of newly generated commercial TRU waste. The volumes of commercial TRU generation, which may require retrievable storage followed by processing and disposal, are projected in Figure 2-3. The upper estimate assumes spent fuel reprocessing, and is based on the maximum nuclear power capability likely to existing in the United States by the year 2000. The lower estimate assumes a oncethrough uranium cycle and represents wastes from expected decontamination of commercial facilities, research, and commercial uses of transuranics. Projected volumes of commercial LLW are shown in Figure 2-4. 

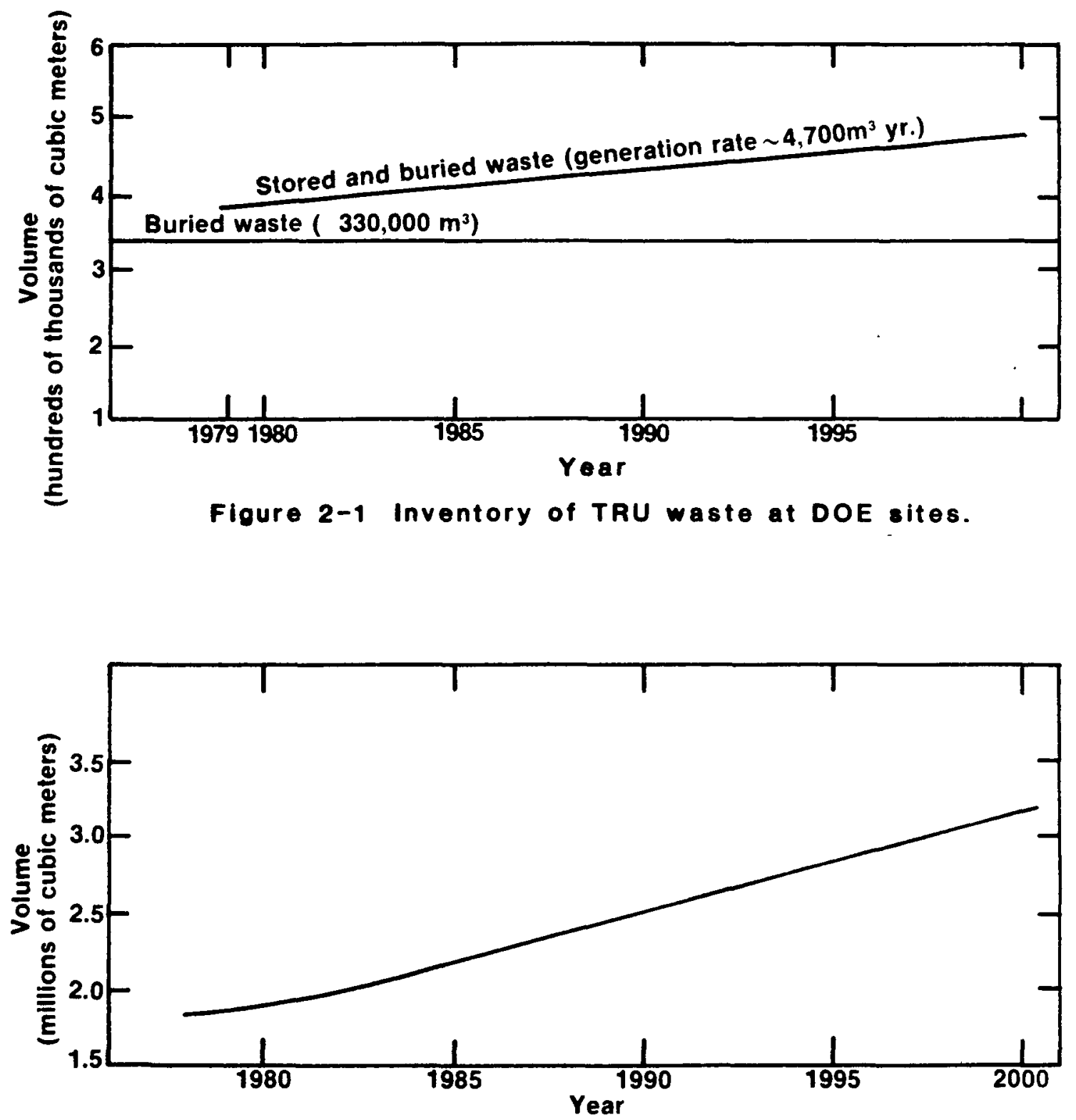

Figure 2-2 Inventory of LLW at DOE sites 


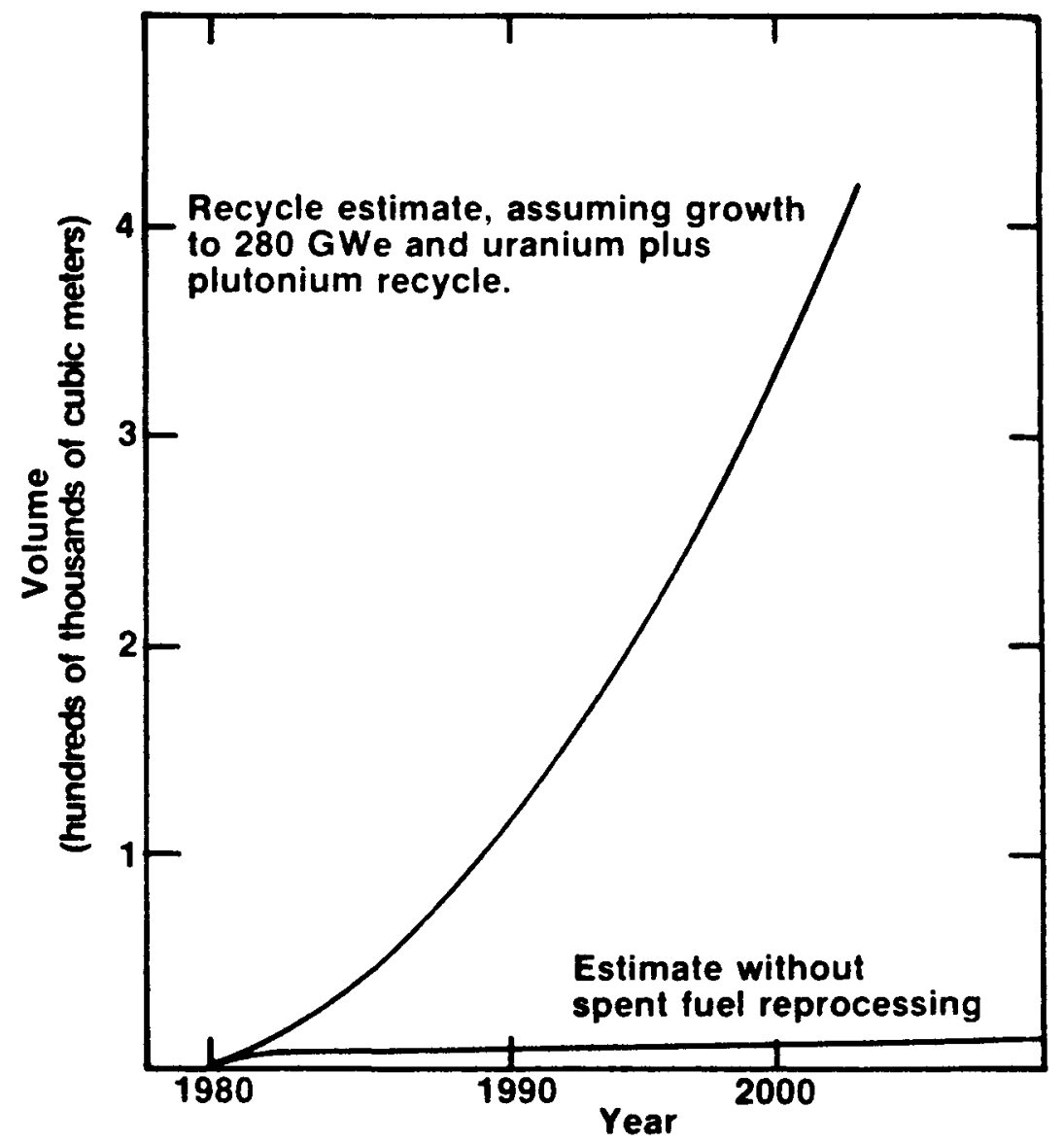

Figure 2-3 Projected volumes of stored commercial TRU waste. 


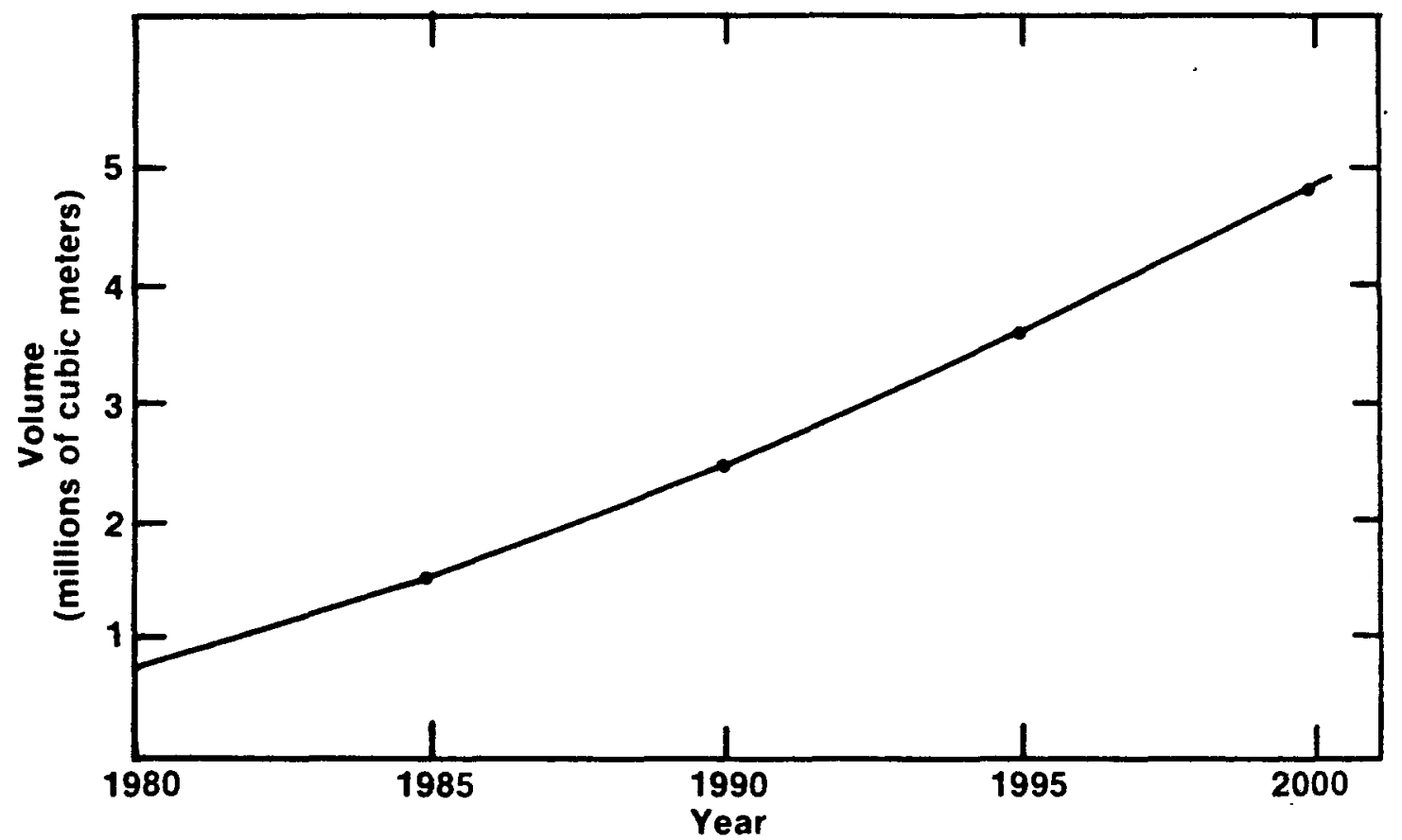

Figure 2-4 Projected volumes of commercial LLW 
The capacity of the commercial burial sites may not, however, be the most significant factor in continued commercial LLW disposal. Recently the South Carolina state government mandated a $25 \%$ reduction in waste volume accepted in 1981 and a 50\% reduction in 1982 at the Barnwell disposal site. Incineration of combustibles would result in far more effective utilization of this reduced capacity.

Usable commercial capacity may be further reduced due to a recently passed initiative in the state of Washington, the location of the Hanford disposal site. This initiative bans the receipt of any waste generated outside the state, unless the generating state has joined in a regional compact with Washington State starting in mid 1981. This initiative will likely force a larger burden on the other two sites, again emphasizing the need to use the capacity at those sites as effectively as possible. Implementation of commercial waste incineration could result in a reduction in commercial waste volume. It is difficult to exactly assess the percentage of commercial waste that is combustible, but a figure of $50 \%$ could be used to estimate the waste volume reduction possible through incineration. The volume reduction obtained by incineration is dependent on the degree of compaction of the feed stream and on the product form required. If immobilization of the ash is required for transportation and storage, the weight and volume reduction may be less.

\subsubsection{Capacities and Effect of Incineration ${ }^{1}$}

Table 2-7 shows the amounts of wastes accumulated by 1980 , the projected generation rates, the estimated accumulated volume by 2000 , and the total capacities of present sites for stored DOE TRU waste, DOE LLW, and commercial LLW. The capacity for DOE to store TRU waste is sufficient for well over 50 years at present generation rates, except for selected sites such as ORNL, which would fill if transportation of TRU wastes was not allowed. If expansion of DOE LLW and commercial waste sites into . presently available areas is allowed, these wastes also have enough room for burial through the year 2000 . 
TABLE 2-7 SUMMARY OF WASTE VOLUMES

\begin{tabular}{|c|c|c|c|c|}
\hline Waste & $\begin{array}{c}\text { End of } 1980 \\
\text { Volume }\end{array}$ & $\begin{array}{c}\text { Average } \\
\text { Generation } \\
\text { Rate } \\
\end{array}$ & $\begin{array}{l}\text { Volume } \\
\text { By } 2000\end{array}$ & Capacity \\
\hline & $\mathrm{m}^{3}$ & $m^{3}$ & $m^{3}$ & $\mathrm{~m}^{3}$ \\
\hline $\begin{array}{l}\text { DOE TRU } \\
\text { DOE LLW }\end{array}$ & $\begin{array}{r}55,400 \\
1,847,000\end{array}$ & $\begin{array}{r}4,700 \\
69,300\end{array}$ & $\begin{array}{r}149,400 \\
3,233,000\end{array}$ & $\begin{array}{c}750,000 \\
>5,000,000 * 2\end{array}$ \\
\hline $\begin{array}{c}\text { Commercial } \\
\text { Waste }\end{array}$ & 761,000 & $\approx 202,000 * 1$ & $4,800,000$ & $3,647,000 *^{3}$ \\
\hline
\end{tabular}

${ }^{1}$ Predicted rate is actually not linear.

$\star^{2}$ Exact volume not defined since several sites have significant undeveloped capacity.

$\star^{3}$ Commercial capacity if expansion is allowed will be $15,000,00 \mathrm{~m}^{3}$.

Radioactive waste inventories represent an extremely heterogeneous group of liquid and solid materials with physical and chemical properties varying over a wide compositional range.

Estimates of the percentage of combustibles, by volume, generally range from 25 to $50 \%$. These estimates vary from site to site and also depend on estimated compaction factors and whether volumes "as generated" or "after compaction" are used. One estimate ${ }^{2}$ of fuel cycle solid waste volume distribution at SRP showed $72 \%$ low level plus TRU combustibles.

An example of the effect of incineration on stored TRU waste volumes is shown in Figure 2-5. The effect of incinerating only the newly generated combustible waste and for incinerating both newly generated and previously stored combustible wastes are shown. For these 1ines, 25\% of the wastes are assumed to be combustible and a reduction factor of $20: 1$ is assumed for storage of ash and off-gas treatment products as compared to the original combustible waste volume. The stored waste is assumed to be incinerated over a 20-year period. A fourth line on Figure 2-5 shows the effect of incinerating newly generated and stored TRU waste if $50 \%$ of the waste volume is assumed to be combustible. 


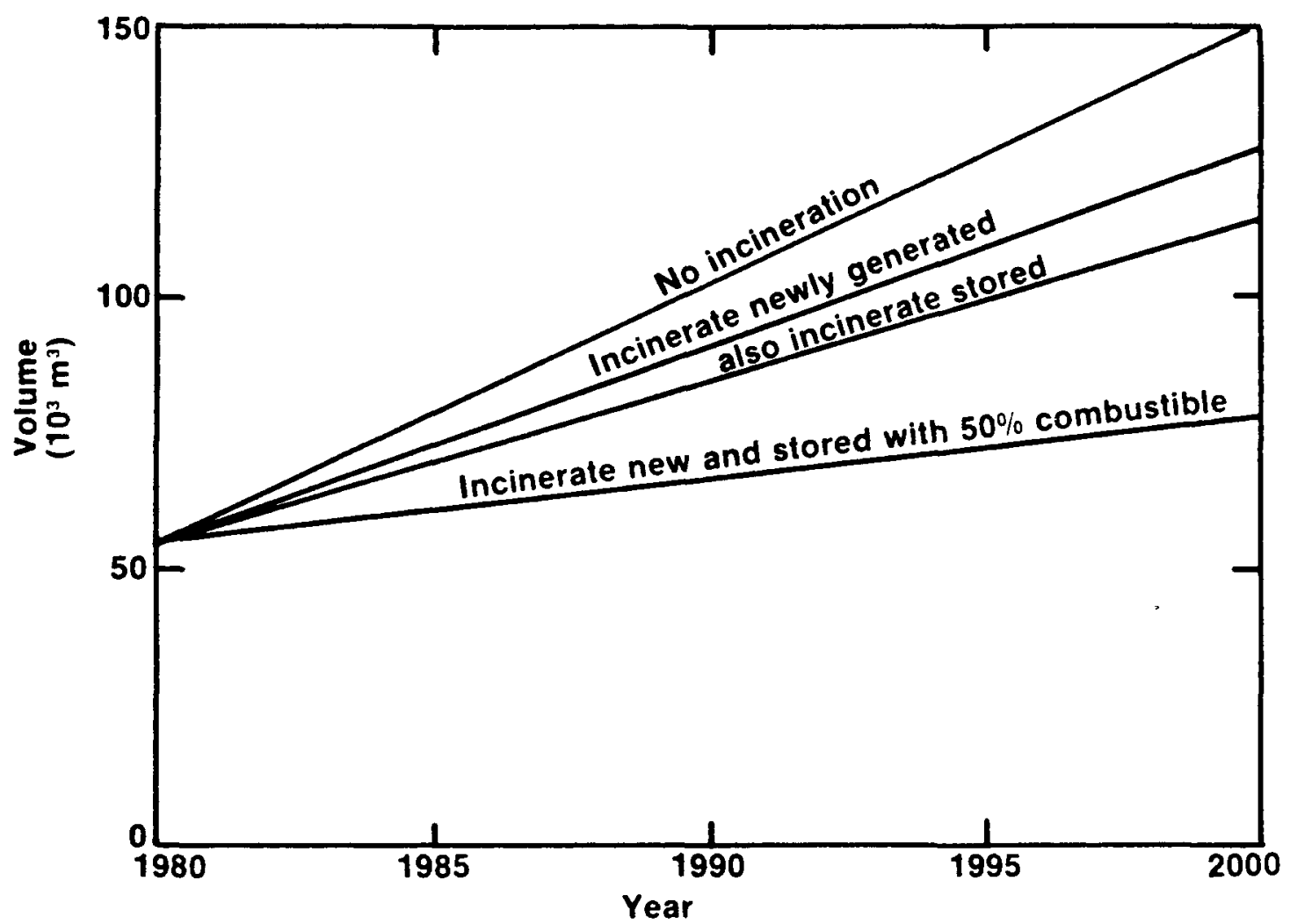

Figure 2-5 Effect of incinerating DOE TRU wastes.

The total capacity of storing TRU waste over the period 1980-2000 is adequate. The capacity remaining at the seven major DOE storage sites is more than $745,000 \mathrm{~m}^{3}$, and exceeds $10^{7} \mathrm{~m}^{3}$ if undeveloped, but accessible, storage areas are included. The volume of TRU waste that will be generated between now and the year 2000, even the volume projected by high estimates, is less than $500,000 \mathrm{~m}^{3}$. Thus, even if the DOE becomes responsible for commercial TRU waste and the high estimate of TRU waste generation from uranium-plutonium recycle proves to be correct, additional storage sites would not be required. This conclusion excludes political considerations, and depends on the assumption that storage space is interchangeable, i.e., that storage space at NTS can be used as easily a storage space at Hanford. A look at the capacity of individual sites, however, does show an impending shortage of space at ORNL (see Table 2-8). 


\begin{tabular}{|c|c|c|c|}
\hline Site & $\begin{array}{l}\text { Projected } \\
\text { Storage Rate }\end{array}$ & $\begin{array}{l}\text { gh-Estima } \\
\text { 20-Year } \\
\text { Capacity } \\
\text { Needed }\end{array}$ & $\begin{array}{l}\text { Present } \\
\text { Available } \\
\text { Capacity }\end{array}$ \\
\hline & $m^{3} / y r$ & $m^{3}$ & $m^{3}$ \\
\hline $\begin{array}{l}\text { Hanford Site } \\
\text { INEL } \\
\text { LANL } \\
\text { NTS } \\
\text { ORNL } \\
\text { Pantex Plant } \\
\text { SRP }\end{array}$ & $\begin{array}{r}1,200 \\
2,600 \\
580 \\
25 \\
150 \\
1 \\
150 \\
\end{array}$ & $\begin{array}{r}30,000 \\
65,000 \\
14,600 \\
600 \\
3,800 \\
2 \\
4,500 \\
\end{array}$ & $\begin{array}{r}285,000 \\
270,000 \\
12,350 \\
175,000 \\
1,200 \\
100 \\
6,350 \\
\end{array}$ \\
\hline Total & 4,700 & 118,500 & 750,000 \\
\hline
\end{tabular}

The DOE has always intended the retrievable storage of TRU waste to be an interim measure, pending the availability of a permanent repository. Retrievable storage can be continued, however, until DOE policy changes or environmental analyses dictate otherwise. If necessary, waste in weakened containers could be repacked to extend storage life. The burial grounds containing TRU waste are routinely monitored, and no hazard exists to ground water aquifers. This practice will continue until the environmental impacts of long-term management options for the buried waste are evaluated. The DOE plans to implement long-term waste management practices as soon as the technology is demonstrated and the environmental impacts are evaluated. 


\subsection{INCINERATION TECHNOLOGY}

\subsection{Background}

Incineration is defined as the act of burning to ashes or the procedure of heating organic substances with free access to air until only ashes remain. There are essentially two types of incineration. These are burning with an open $f l$ ame where an excess of oxygen is supplied, and starved air incineration where less than the stoichiometric amount of oxygen is supplied. The different incinerator types now in use come from attempts to improve the contact between air and combustibles, alternate ways of heating the materials to combustion temperature, and various ways of treating the off gases. Acid digestion is a special case where an oxidizing agent other than air is used.

Open flame burning is the oldest form of incineration used by man. Open pit and natural draft burning are simple examles of this technique. Improvements to open pit burning induce more comlete incineration by increasing the contact between the oxidizing air and the combustibles. These improvements include open grates which allow the air to flow up through the combustibles or stirring mechanisms in the agitated hearth, multiple hearth, and moving grate type incinerators. Agitation is supplied by a continuous tumbling action in a rotary kiln incinerator. The fluid bed and molten salt incinerators use the agitation of the air moving through the bulk medium.

Partial pyrolysis (decomposition and release of combustible gases) is achieved in starved air incineration by sealing the incineration chamber and controlling the amount of air fed into the chamber. Pyrolysis incinerators produce ash with a larger carbon content than with open burning, but have the advantage of less ash in the off-gas stream. The pyrolysis incinerators often have one or more secondary chambers where excess air . is added to burn the pyrolysis gases. The controlled air and electric air units are operated close to stoichiometric or slightly substoichiometric 
air in primary burning chambers followed by excess air in the secondary burning chambers.

Many methods can be used to heat the combustibles to a temperature at which incineration can take place, but there are two general classes. These are direct fired incinerators and indirectly fired incinerators. In a direct fired incinerator oil, gas, or some other fuel is burned in the chamber to bring the incinerator up to operating temperature and to supplement the trash burning if required. The agitated hearth, controlled air, cyclone drum, and rotary kiln incinerators use this type of firing. The indirectly fired incinerators are heated from outside the combustion chamber. The electric controlled air and acid digestion units use indirect heating. The fluidized bed and molten salt incinerators use a combination of these.

Many of the differences in incineration units are prompted by different ways of treating the off-gases. For instance, the fluidized bed and molten salt incinerators neutralize acidic off-gases in the bed materials. They have dry off-gas systems using sintered metal or bag filters. Most incinerators must use wet scrubbing systems to remove the acidic gases from the off-gas stream. These usually include a caustic scrubber to neutralize the acidic gases. All radioative waste incinerators also include one or more stages of HEPA filtration for final particulate removal.

\subsection{Previous Experience}

A wide range of incineration systems have been installed for radioactive use in the U.S. and foreign countries. While some of these systems have been successful in processing large volumes of waste and serving a needed function, many problems in operation and maintenance have been identified. 


\subsubsection{Benefits and Problems}

The incineration of radioactive wastes was begun in the U.S. in the early 1950's in what was then the Atomic Energy Commission (AEC) weapons facilities. Private companies engaged in fuel fabrication launched incineration activities at about the same time. Incineration has proven to be a successful method to reduce both the volume and weight of bulky combustible wastes. Volume reductions of 40 to 1 and weight reductions of 10 to 1 are both common in various incineration methods. The earlier incinerators were relatively simple in design, with most featuring one or two combustion chambers that were either natural gas or electrically heated to temperatures ranging from $800^{\circ}$ to $1200^{\circ} \mathrm{C}$. Some, such as the LANL basket incinerator, were small capacity units designed for plutonium recovery operations. The LANL unit was operated very successfully for this application for a period exceeding 25 years, with only one major rebuilding operation. Other larger units, such as the $20-\mathrm{kg} / \mathrm{hr}$ Rocky Flats incinerator, burned large volumes of radwaste, but did require a relatively high amount of maintenance. The long operating history of these units have proven the value of incineration for (1) weight and volume reduction, (2) elimination of flammable and/or pyrophoric materials, and (3) conversion of bulky combustibles to a form amenable to actinide recovery operations.

Operation of the early incinerators was not without problems, and many units were modified or completely replaced to improve performance or to achieve operational status. Some of the early units were of a small scale, designed for minimal throughputs of recoverable wastes. These small units were generally more successful than larger units designed for greater capacities of wastes of diverse material content.

Problems with these early units were varied, but most of the problems were in the areas listed below:

1) Contamination containment

2) Equipment corrosion 
3) Short refractory life

4) Mechanical failures

5) Incomplete combustion

6) Off-gas cleanup

7) Criticality control

8) Fires and explosions

9) Operational complexities

10) Maintenance complexities

The problems associated with nuclear waste incineration were, in many cases, the same as those associated with other industrial or municipal incineration operations. It became obvious, however, that these problems grew in magnitude when radioactive contamination contanment and criticality control were added to the incinerator requirements. Other problems proved to be a result of the nature of the material content of the individual radwastes. Common examples of this type of problem were:

1) The high ratio of PVC plastics $(\approx 40 \mathrm{wt} / \%)$ in radwastes that decompose to $\mathrm{HCl}$ during incineration. This has been a significant factor in the high metal corrosion rates in many incinerators.

2) Leaded gloves, lead tape, and small pieces of lead shielding in the combustible wastes form glassy compounds that attack refractory and reduce the 1 ife.

3) Many radwaste combustibles have been exposed to acids and/or solvents and become pyrophoric by the time they reach an incineration process. This fact has contributed to fires and explosion problems in sorting and feeding areas. The presence of acid on combustibles also adds to the metal corrosion problems.

4) The radioactivity of the waste necessitates a containment system that is not necessary in other conventional incineration operations. The containment system contributes to mechanical complexities, sealing complexities, cooling problems, and maintenance difficulties. 
5) The possibility of a criticality excursion is another concern unique to nuclear waste incineration. Many prohibitive design and operational restraints must be imposed to insure a critically safe operation.

Finding solutions to these problems has been the focus of recent research on radwaste incinerators.

\subsubsection{Radwaste Incinerators}

The major incinerators used by both DOE (AEC and/or ERDA) and commercial companies are listed below. Additional information on these incinerators is tabulated in Appendices $A$ and $B$.

\section{United States Radwaste Incinerators ${ }^{3}$}

Argonne National Laboratory - single chamber, gas fired ARHCO - dual chamber, moving grate Babcock and Wilcox - single chamber Babcock and Wilcox - dual chamber, gas fired Nuclear Fuel Division Bettis Atomic Power Laboratory - single chamber, cyclone air feed Douglas United Nuclear - natural draft, open bit burning G.E. Atomic Power Equipment Dept. - Triple chamber, gas fired G.E. Nuclear Fuel Plant - vortex burner, gas fired Goodyear Atomic Corp. - dual chamber, gas fired Gulf General Atomics - dual chamber, gas fired Kerr-McGee Nuclear Corp. - dual chamber, gas fired Knolls Atomic Power Laboratory - single chamber, pure $\mathrm{O}_{2}$ LANL - single basket, electrically heated Metals and Controls-...-... Mound Facility - single basket, electrically heated National Lead of Ohio - dual chamber, gas fired Nuclear Fuel Services - dual chamber, gas fired ORNL $(K-25)$ - dual chamber, gas fired 
ORNL (Y-12) - single chamber, gas fired

Pratt and Whitney Aircraft--.------

RFP - dual chamber, gas fired

Shippingport Atomic Power Station - cyclone air feed

United Nuclear Corp. - single chamber, gas fired

U.S. Army Nuclear - dual chamber, cyclone air feed

Defense Laboratory

Westinghouse Nuclear - dual chamber, excess air burner

Fuel Division

Yankee Rowe Atomic Electric Co. - cyclone air feed

During the same time period that the U.S. radwaste incinerators were being developed and becoming operable, a number of foreign countries were also launching incineration projects. Foreign counterparts paralleled U.S. experience in that many units required modifications and/or rebuilding to achieve operational status or increase throughput. Maintenance was generally high, but still the advantages of incineration were sufficient to spur the continuation of operations. A list of past and present foreign radwaste incinerators follows. These incinerators are further described in Appendix $C$.

\section{Foreign Radwaste Incinerators ${ }^{4}$}

\section{United Kingdom}

Harwe11, Berkshire - single chamber, gas fired

Windscale, Cumberland - four chamber, electrically heated

\section{France}

Cadaroche Nuclear Study Center - dual chamber

Fontenay-Aux-Roses (CEN-FAR) - dual chamber, oil and propane fired

National Center for Scientific Research - dual chamber, oil fired (CNRS), Strasbourg, Cronenbourg 
Marcoule Center of Plutonium Production - triple chamber, gas

fired, Bagnols-sur-Ceze

Center of Nuclear Studies - dual chamber, Genoble (CEN-G)

Belgium

Belgium Nuclear Center - triple chamber, gas fired, Mol (CEN)

Belgium Nuclear Center - slagging type, dual chamber, Mol (CEN)

Republic of Germany

Karlsruhe Nuclear Research Center - dual chamber, electrically preheated,

Julich Nuclear Research Center - dual chamber, controlled air.

Nukem, Hanau Ger. - agitated pyrohydrolysis

India

Bhahha Atomic Research Center - dual chamber, oil fired, Trombay

Japan

Japanese Atomic Energy Research Institute - dual chamber, oil fired (JAERI), Tokai

Oarai Research Establishment - four chamber, $0 i 1$ and gas fired (JAERI), Darai

Canada

Chalk River Nuclear Laboratories - dual chamber, gas fired (CRNL), Ontario

Most of the U.S. and foreign incinerators listed were patterned after commercial industrial units in use at the time. Modifications were necessary, of course, to provide for alpha, gamma, and neutron containment; removal of radioactive particulate from off-gases; and criticality safety. From the record of modifications and rebuilding operations, it became - apparent that many conventional incinerators were not well suited to radwaste incineration. Consequently, people in DOE and industry began 
formulating incineration systems specifically for nuclear wastes. Some systems were based on a proven commercial system, while others were completely new designs. All attempted to provide the unique requirements for radwaste incineration as an integral part of the design. In the U.S. there were several such incinerators designed and tested in the 1970's that are now ready for practical application. Most of these units were funded by DOE and built and tested in DOE facilities; however, two strictly commercial designs are also being considered for nuclear applications. A list of these radwaste specific incinerators is shown below:

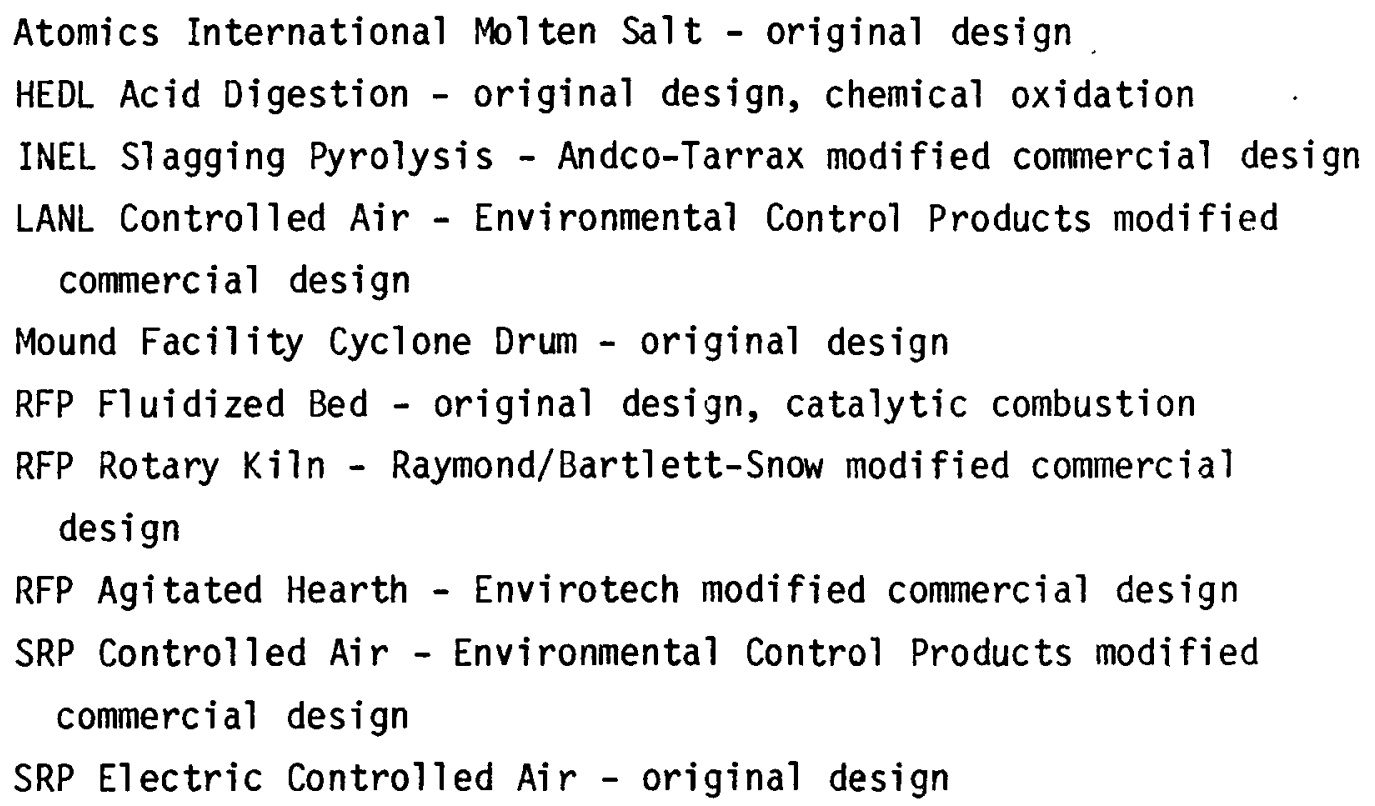

These incinerators, except the SRP controlled air, are discussed in the next section. The SRP unit is patterned after the LANL controlled air incinerator and will possess the same general characteristics, excepted for a greater capacity.

\subsection{Characteristics and Capabilities of Recently Developed Incinerators}

The operating characteristics of the incinerators most recently developed and studied for specific application to radwaste (1isted in the last section) are discussed in this section. A brief comparison of the 
TABLE $3-1$
PROCESS CHARACTHATSTICS ON RECEMTY DEVEDOF D TAU INCTNERATION SYSTEMS

cros

AGITATED HEARTH

LANL CONTROLLED AIR CYCLONE DRUM ELECTRIC
CONTROLLED

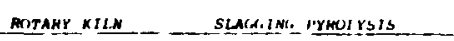

\begin{tabular}{|c|c|c|c|c|c|c|c|c|c|}
\hline $\operatorname{In} \times 4 I I I N$ & HEEDL & RPP & uNL & MOUND & $S R L$ & $\mathrm{RPF}$ & $\begin{array}{l}\text { NOWE INSTALLED AT } \\
\text { NUCLAAR SITE }\end{array}$ & arr & MEANA D I ON INEL L \\
\hline process besusiption & 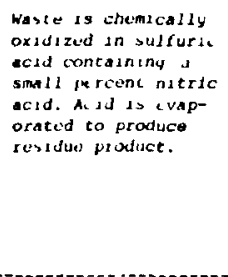 & 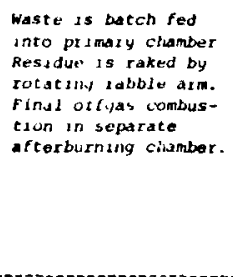 & 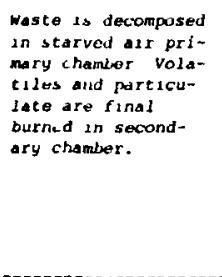 & 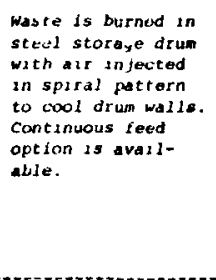 & 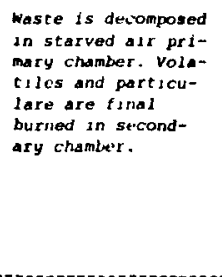 & 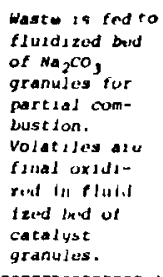 & 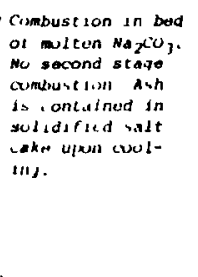 & 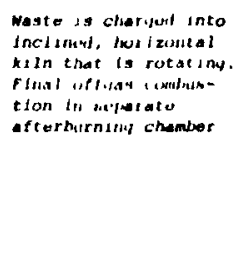 & 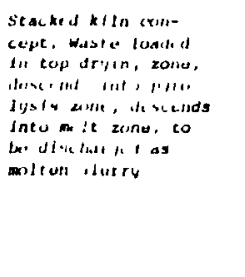 \\
\hline Unique Capabilaties & 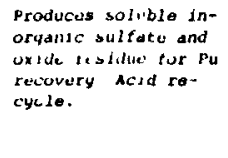 & 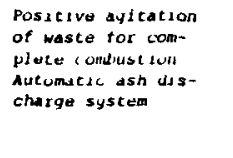 & 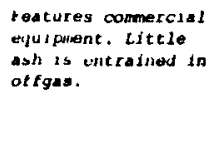 & $\begin{array}{l}\text { Provides capebility } \\
\text { to incinc tate waste } \\
\text { in stordye drum, } \\
\text { without sortiny or } \\
\text { precteatment. }\end{array}$ & $\begin{array}{l}\text { Slectrically hoated. } \\
\text { Slow gas flows en- } \\
\text { train litet ie ash in } \\
\text { offyas. }\end{array}$ & 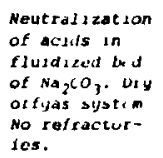 & 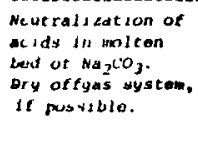 & 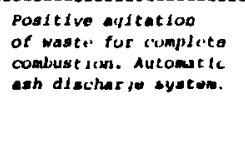 & 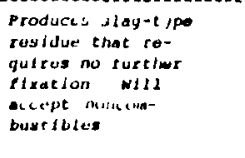 \\
\hline
\end{tabular}

\begin{tabular}{|c|c|c|c|c|c|}
\hline $\begin{array}{l}\text { Desiun Capaciey } \\
(k, / h r)\end{array}$ & 10 & 70 & 45 & 27 & s \\
\hline $\begin{array}{l}\text { Opuruting rempera- } \\
\text { cures }\end{array}$ & $25 \mathrm{C}^{\circ} \mathrm{C}$ & $800-1000^{\circ} \mathrm{C}$ & $800 \cdot 1100^{\circ}$ & $1100-1300^{\circ} \mathrm{C}$ & $100-1000^{\circ} \mathrm{C}$ \\
\hline $\begin{array}{l}\text { Rave yathisals Re- } \\
\text { quired }\end{array}$ & $\begin{array}{l}\text { Sulfuric scid, nicric } \\
\text { dcid, scrubber caus- } \\
\text { tic. }\end{array}$ & scrubber caustav & Scrubber caustic & Scrubber caust ic & Scrubber caustic \\
\hline $\begin{array}{l}\text { Auxp11tary Reat } \\
\text { Requised }\end{array}$ & $\begin{array}{l}\text { Second chamber and } \\
\text { acld evaporator are } \\
\text { oloct risces lily heated. }\end{array}$ & $\begin{array}{l}\text { Fuel onl fired for } \\
\text { heatup and as } \\
\text { neerded during } \\
\text { operation. }\end{array}$ & $\begin{array}{l}\text { Gas fired for theat- } \\
\text { up and as neaded } \\
\text { during operation. }\end{array}$ & $\begin{array}{l}\text { Fuel onl fired for } \\
\text { hestup. None during } \\
\text { operation. }\end{array}$ & Eluctricelly seated. \\
\hline
\end{tabular}

$82 \quad 5$

1

850

$50 \mathrm{C}-600^{\circ} \mathrm{C} \quad 800-9000^{\circ} \mathrm{C} \quad 000-1000^{\circ} \mathrm{C} \quad 800-1 \mathrm{C} 50 \mathrm{C}^{\mathrm{C}}$

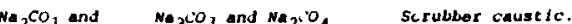
$\mathrm{Cr}_{2} \mathrm{O}_{3}$ cotelyst

a.rk, was, and
coll ias ibly Na, col,

Heatup with propane fired for pual all tirud ror fucl bill filed for

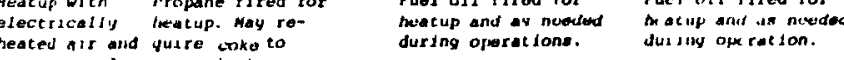

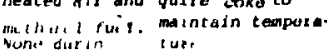

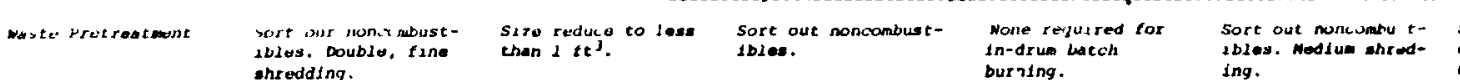

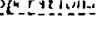

opracison.

coarsc end throditing. fine shred-
dinq.

\begin{tabular}{|c|c|}
\hline waste Feed System & Hum foeder. \\
\hline $\begin{array}{l}\text { Product Removal } \\
\text { system }\end{array}$ & $\begin{array}{l}\text { Residus slurry in- } \\
\text { teralttentiy a1r- } \\
\text { iffed from re- } \\
\text { action chamber. }\end{array}$ \\
\hline
\end{tabular}

Ram feeder.

\section{Ram foeder.}

None. Ran foeder.

screw feoder.

Ash raked out by

finish of batch

Gravity ash dropaut
end pnoumatic trena

Ash remains in drum. Eotch gravity dis-
Can be respoved by

Cont inuous
gravity dis

gravity dis
charye to

screw con
veyor.

Produc Form

400 maneral ash

Low carbon, min-
arel ash.

Low carbon, min-

15x carbon, mineral st carbon, maneral
ash.

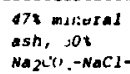
$\mathrm{Na}_{2} \mathrm{SO}_{4}, 128$
$\mathrm{Carlar}, 118$

is oftyas systom

noo packed scrub

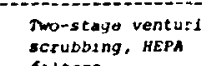

Quethich column, ven-

Quethich column,
turl 1 scrubber
packed col scrubber, HEPA $f+1$ Elunatur for reters.

ture scrubs, ven- venturi giencich, cyclonit unroduling.

sise rusuce to swret anit blesut in
coust end burk

\begin{tabular}{|c|c|c|c|c|c|}
\hline 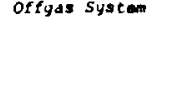 & $\begin{array}{l}\text { bors. acid frac- } \\
\text { tiunatur for re- } \\
\text { cycle, HEPA fil- } \\
\text { ters. HCL vent }\end{array}$ & $\begin{array}{l}\text { scrubbing, HEPA } \\
\text { filets. }\end{array}$ & $\begin{array}{l}\text { turt } 1 \text { scrubber, } \\
\text { packed col umn } \\
\text { strubber, HEPA fil- } \\
\text { ters. }\end{array}$ & $\begin{array}{l}\text { turs scrubber, } \\
\text { dem. ster, HEPA } \\
\text { filters. }\end{array}$ & $\begin{array}{l}\text { fibroun-led scrub- } \\
\text { ber, packed bed } \\
\text { contactor, MEPA } \\
\text { fiters. }\end{array}$ \\
\hline $\begin{array}{l}\text { Materials of con- } \\
\text { struetion }\end{array}$ & $\begin{array}{l}\text { Classud Lined } \\
\text { steel. }\end{array}$ & $\begin{array}{l}\text { Refractory lined } \\
\text { stael. }\end{array}$ & $\begin{array}{l}\text { Retractory 1ined } \\
\text { steel. }\end{array}$ & $\begin{array}{l}\text { Stael drum, re- } \\
\text { fractory Linad } \\
\text { header. }\end{array}$ & $\begin{array}{l}\text { Refsactory lined } \\
\text { steet. }\end{array}$ \\
\hline
\end{tabular}
separaturs sinteresd metal
filters, Hewa
filters.

Pneumatic foedor.
Poriodic dralning
of sale-esh al
ture.

Ran fouder size to 22 is.

struetion

Geometricalli" safo

Adminigrsative. Anmiuistrative.

Administ rative

$316 / 34$ stein
iess stael.

254 mineral ash

15. $\mathrm{NaCl}_{2} \mathrm{CO}$.

wath

lawh.

cerbon, minerel

vist eliminator.

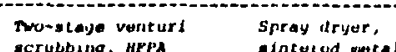

scrubing, HFPA
filters.

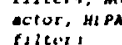

ketracicosy itheal

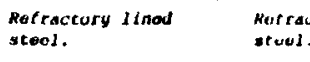

Adminietrativo.

Auminieciacive 
nine units is presented in Table 3-1, that gives the reader a quick review of each unit's operation. The following sections discuss each incinerator separately. This discussion treats the waste handling capabilities (including capacity), acceptable waste size, and ability to handle various waste types. The ability to handle varying radioactivity levels and allow actinide recovery, and the remotability are also discussed. Major advantages and disadvantages are then listed and potential applications of each incinerator are given.

\subsubsection{Acid Digestion (HEDL) $)^{5}, 6,7$}

\section{Solid Waste Capabilities}

The process has been demonstrated with paper, rags, wood latex rubber, Hypalon rubber, Neoprene rubber, PVC plastic sheet, ion exchange resins, and polyurethane plastic sheet. FLuorinated wastes cause corrosion to the glass lined equipment.

\section{Capacity}

The original processing rate was about $3.0 \mathrm{~kg} / \mathrm{hr}$, but a new high-rate digester has been added to increase the capacity to $10 \mathrm{~kg} / \mathrm{hr}$.

\section{Waste Size}

Waste must be shredded to approximately $1 / 2$ in. size prior to ram feeding into the digester. Double shredding is some times required to avoid stringy material. The shredder will accept waste up to $1 \mathrm{ft}$ by $2 \mathrm{ft}$ in size.

\section{Noncombustibles}

Waste is hand sorted to remove noncombustibles prior to shredding. An air classification system is employed to remove tramp metal from the 
shredded waste. Small pieces of metal that may inadvertently reach the digester are slowly dissolved into the acid; acid-resistant materials must be periodically removed.

\section{Moisture Content}

The unit can accommodate damp combustibles. Free water would be undesirable in the waste shredding area.

\section{Acid Producing Solids}

The system is resistant to acids produced by PVC plastic, etc. Not all acids are recovered in the off-gas scrubbing system, however, and some nitric and hydrochloric vapors are vented to the atmosphere.

\section{Volatile Solids}

The low temperature operation $\left(250^{\circ} \mathrm{C}\right)$ does not promote volatilization, and most volatile materials will be decomposed and dissolved into the acid system.

\section{Liquid Waste Capabilities}

The processing of organic liquids by acid digetion is somewhat limited because the noncombustible and volatile liquids vaporize and leave the digester with the off-gas. Vacuum pump $0 i 1$ and tri-n-butyl phosphate have been digested, but normal paraffin hydrocarbons are not processed at present.

\section{Capacity}

Unknown. 
Acid Producing Liquids

Unknown.

\section{Aqueous Liquids}

The process can accept water and aqueous waste and a capacity of $20 \mathrm{~kg} / \mathrm{hr}$ of water has been demonstrated.

\section{Radioactive Waste Capabilities}

\section{Design Potential}

The system was designed to process TRU and LLW containing plutonium ranging from very low levels to kilogram quantities.

\section{Nuclear Safety}

The facility at HEDL is designed in dimensions safe for multi-kilogram quantities of plutonium. Administrative control is utilized to hold the actual fissile material inventory below $2 \mathrm{~kg}$.

\section{Degree of Automation}

The equipment is housed in glove boxes for alpha containment. Waste is removed from drums and placed into an airlock on the feed preparation box. It is then hand sorted in the glove box to remove noncombustibles. The combustibles are then thrown into the shredder for size reduction followed by air classification for tramp metal removal. The prepared feed is then placed in a conveyor that transfers it to the feed hopper for the ram extruder. The system is operated from a separate control room. Dried residue must be removed from an evaporator and bagged out of a glove box . for subsequent plutonium recovery or storage. 


\section{Actinide Recovery}

When plutonium contaminated combustibles are processed by acid digestion, the resulting residue contains aqueous-soluble plutonium sulfate. The plutonium sulfate has been found to be quite soluble in $\underset{7 M}{\mathrm{HNO}_{3}}$. Once into solution, it can be purified by ion exchange and subsequently converted to $\mathrm{PuO}_{2}$ by oxalate precipitation and calcination.

\section{Major Advantages}

- Designed to process high levels of fissile content waste.

- Soluble residue for actinide recovery.

- Low temperature operation.

\section{Major Disadvantages}

- Maintenance of glass lined equipment.

- Small feed size requires shredding.

- Acid gases are vented to atmosphere.

- Adaptable for limited number of organic liquids.

\section{Potential Applications}

The acid digestion system has been demonstrated for processing most forms of solid waste, but it is quite limited in the number of organic liquids it can decompose. The fact that the process can be designed in geometrically favorable dimensions makes it valuable for processing wastes containing high levels of plutonium. Subsequent recovery of actinides is al so enhanced by the soluble nature of the sulfate residue it produces. In addition, the system will tolerate a large variety of solids, including glove box gloves. At the present stage of development, the system is best suited to small volume waste streams, but by sacrificing critically safe . dimensions it could be scaled up considerably. The glass lined equipment is vulnerable to fluoride attack, so fluorinated wastes must be excluded. 
Since this unit is operated in a glove box system, no remote operating techniques have been tested and a very extensive development program would be required to adopt the process to a remote operation. However, since it is essentially a liquid process, it could offer some advantages for remote hot cell type operations.

\subsubsection{Agitated Hearth (RFP)}

\section{Solid Waste Capabilities}

The unit at RFP is not yet in operation. The projected use for this incinerator is the burning of $L L W$, essentially suspect waste from production areas of the plant. The materials in this type of waste would consist mainly of paper, polyurethane, PVC plastic, latex rubber gloves, and cloth.

\section{Capacity}

The design capacity is $70 \mathrm{~kg} / \mathrm{hr}$.

\section{Waste Size}

The only size restriction is that imposed by the ram feeding system, which will accept waste packages approximately $1 \mathrm{ft}^{3}$ in size.

\section{Noncombustibles}

The incinerator will tolerate small noncombustibles, but large items must be removed prior to feeding.

\section{Moisture Content}

The system should tolerate relatively wet solids, since the waste is tumbled over the hearth by rotating rabble arms. 


\section{Acid Producing Solids}

High acid waste or high concentrations of PVC plastic may cause corrosion damage to the metal rabble arms in this unit. Acids in the off-gas will be neutralized in the caustic scrubbing system.

\section{Volatile Solids}

Operating temperatures of 800 to $1000^{\circ} \mathrm{C}$ will promote volatilization of some waste materials. The formation of lead compounds on the incinerator and afterburner refractory lining presents the greatest potential problem.

\section{Liquid Capabilities}

The RFP unit will not be equipped for burning liquids because of nuclear safety concerns. In applications that do not involve fissile materials, this type of incinerator could be equipped to spray organic liquids into the combustion chamber.

\section{Capacity}

Unknown.

\section{Acid Producing Liquids}

Acids from burning chlorinated hydrocarbons would not be desirable because of the presence of metal components in the incinerator.

\section{Aqueous Liquids}

If no fissile materials were present, some aqueous liquids could be sprayed into the combustion chamber along with auxiliary fuel. Some waste chemicals could prove to be damaging to metal parts and refractories. 


\section{Radioactive Waste Capabilities}

\section{Design Potential}

The RFP unit is a commercial design for processing non-glove box generated waste. Only LLW that has been drum counted and determined to have no more than background radioactivity will be burned.

\section{Nuclear Safety}

Nuclear safety will be achieved by administrative control of materials being charged to the incinerator. The unit will be batch operated, with a period of time at the end of the run when ash is raked out of the unit by thè rotating rabble arms. The system as installed does not incorporate the necessary criticality safety features for processing glove box generated waste with high levels of fissile material.

\section{Degree of Automation}

Wastes will be dumped into a glove box for hand sorting to remove large noncombustibles. The sorted waste will be fed via a ram feeder in $2.3-\mathrm{kg}$ increments over a 5-hour period. Ash will be automatically raked to a dump port at the end of the run. No other hand operation is required except for the removal and replacement of the ash collection drum.

\section{Actinide Recovery}

The unit will produce refractory oxides in the ash that are relatively difficult to dissolve for actinide recovery.

\section{Major Advantages}

- Little waste pretreatment requirements.

- Mechanical agitation of waste during combustion.

- Automatic ash removal. 


\section{Major Disadvantages}

- Maintenance of mechanical equipment in the combustion chamber

- Will accommodate only low levels of fissile materials

\section{Potential Applications}

The agitated hearth incinerator has not been demonstrated in a nuclear waste application; however, the intended use at RFP appears to take advantage of the strong points of the system. With no particular criticality precautions designed into the system, it will best be utilized to burn a large volume, LLW stream. The fact that it will tolerate a moderate amount of noncombustibles is advantageous in that intensive hand sorting can be eliminated. Acid producing waste and lead contaminated wastes should be avoided to decrease the possibility of metal corrosion and refractory degradation. The unit is installed in a canyon for semi-remote operation. However, because of anticipated maintenance problems with refractories and metal corrosion, it is not a strong candidate for remote hot cell type operation.

\subsubsection{Controlled Air (LANL) $)^{9}, 10$}

\section{Solid Waste Capabilities}

The controlled air process has been tested with various cellulosic compounds, polyethylene plastic, PVC plastic, latex rubber gloves, and cartridge filters.

\section{Capacity}

The LANL unit has been demonstrated at the design feed rate of $45 \mathrm{~kg} / \mathrm{hr}$. 
The main ram feeder will accommodate packages up to $1.7^{\prime} \times 2.7^{\prime} \times$ $3.3^{\prime}$. Physical constraints in the feed preparation glove box line limit the package size entering the main ram to $1^{\prime} \times 2^{\prime} \times 2^{\prime}$.

\section{Noncombustibles}

Waste is $X$-rayed prior to incineration to detect any large noncombustible items within the packages. Large noncombustible items are sorted out; small noncombustibles are tolerated.

\section{Moisture Content}

The unit should tolerate relatively damp solids since it is gas fired; there is no provision for agitation of damp materials within the combustion chamber resulting in longer combustion times and more supplemental fuel being required.

\section{Acid Producing Solids}

Large amounts of acidic materials may affect some corrosion damage to the steel incinerator shells and other head end equipment if they are consistently burned. Acids are neutralized in the off-gas scrubbing system on the tail end of the process.

\section{Volatile or Low Melting Solids}

Operating temperatures of 800 to $1100^{\circ} \mathrm{C}$ is sufficient to volatilize some metals and metal compounds. Deposition of corrosive lead compounds on refractories may shorten refractory life if lead containing materials are burned. 


\section{Liquid Waste Capabilities}

The LANL unit has not been demonstrated for incineration of organic or aqueous liquids; however, the unit is presently being modified to test liquid and resin combustion. At present, all waste is $x$-rayed to detect any liquids within the boxed waste.

\section{Capacity}

Unknown. Unit has not been tested with liquids.

\section{Acid Producing Liquids}

Incineration of chlorinated hydrocarbons or other acid producing liquids could present corrosion problems.

\section{Aqueous Liquids}

The incinerator is presently being modified to accommodate liquid feeds.

\section{Radioactive Waste Capabilities}

\section{Design Potential}

The unit at LANL was designed to evaluate and demonstrate the incineration of TRU wastes. The LANL Treatment Development Facility where the incinerator is located, is limited to a plutonium inventory of 100 grams.

\section{Nuclear Safety}

The LANL incinerator is not critically safe by dimension, so adminis. trative control must be utilized for nuclear safety. Boxed waste is assayed for TRU content prior to incineration by use of a LANL-developed 
Multi-Energy Gamma Assay System (MEGAS) installed in the waste pretreatment glove box line. Waste is fed in approximately 6000-gram batches, while a gravity ash dropout collects ash in a hopper for intermittent pneumatic removal. There is no positive removal of ash from the primary chamber hearth until a run is complete; then any remaining residue is removed by vacuum transfer. The system as installed does not incorporate the necessary criticality safety features for processing glove box generated waste with high levels of fissile material. The off-gas scrubbing equipment of the present unit is not safe by dimension but could be redesigned for applications with greater concentrations of fissile materials.

\section{Degree of Automation}

The incinerator is operated from a control room with manual feed preparation. Boxed waste is received in 30-galion drums which are unloaded into the feed preparation glove box. Each box is assayed and x-rayed. If noncombustibles are present, the box is opened, sorted, and resealed prior to insertion into one of two ram feeders. Feeding and control of the incinerator is done from an adjacent control panel. Ash is pneumaticaliy removed from the ash dropout during operation. After a run is completed, the combustion chambers are vacuumed to remove any residual ash deposits.

\section{Actinide Recovery}

The process produces refractory oxides that are not as amenable to actinide recovery processes as those produced by the lower temperature combustion processes.

\section{Major Advantages}

- Limited airflow in the primary combustion chamber reduces ash entrainment.

- Commercially available equipment.

- Built-in TRU assay and x-ray equipment for waste identification. 
- Tolerates small noncombustibles.

- Shredding of feed not generally required.

\section{Major Disadvantages}

- A considerable heal of ash remains in the lower chamber of the incinerator, al though ash is periodically removed during normal operation.

- Will accommodate only low levels of fissile materials.

\section{Potential Applications}

The controlled air system should be useful in processing waste streams containing low levels of TRU elements and relatively large volumes. The $45-\mathrm{kg} / \mathrm{hr}$ unit at LANL could easily be scaled up to accommodate greater amounts of waste. The high fired quality of the ash and the possibility for some retention of ash during operation would be a detriment to the processing of recoverable amounts of fissile materials in this unit. The MEGAS assay unit and $x$-ray equipment on the LANL incinerator is advantageous in maintaining a nuclear safe operation and could be utilized in other incineration systems. High levels of PVC plastics in wastes could eventually present corrosion problems within the system. This unit, as installed at LANL, is a glove box type of operation and semi-remote canyon type operations have not been tested. A considerable development effort would be needed before this system could be considered a strong candidate for remote hot cell type operations.

\subsubsection{Cyclone Drum (MF) $)^{12}, 13,14$}

\section{Solid Waste Capabilities}

The cyclone incinerator has been demonstrated with alpha-contaminated . wastes from Mound Facility that contain paper, PVC plastic, polyethylene plastic, polypropylene plastic, rubber, cloth, and some tramp metal. In 
addition, the system has been tested for burning organic liquids (kerosene) and plastic scintillation vials containing a dioxane-water mixture.

\section{Capacity}

Uncompacted waste are burned at a rate of $27 \mathrm{~kg} / \mathrm{hr}$; compacted material burns somewhat slower.

Noncombustibles

Noncombustibles in waste will have very little effect on operation of the process in batch operation. The high velocity airflow within the drum will promote combustion of flammable materials, even though there may be a large amount of noncombustibles present. If the system were operating on a continuous basis, noncombustibles would have to be sorted out prior to shredding of the material.

\section{Waste Size}

If the system is operated on a batch basis, using each waste drum as a combustion chamber, there is no size restrictions other than those imposed by the storage drum itself. When operating continuously, a stainless steel drum is left in place and waste is pneumatically charged. This mode of operation necessitates the shredding of wastes to a size of approximately 1 in. $^{2}$.

\section{Moisture Content}

Ignition of waste in the storage drums has presented some problems in the Mound system. Development work was started on a system in which an electrical arc is used to ignite a liquid fuel. The procedure proved troublesome in the high velocity airflows within the burning chamber. Very wet wastes would not ignite easily in a batch operation, and they would not transfer well pneumatically in the continuous mode; consequently, it 
appears that the process may be quite sensitive to high moisture content in wastes.

\section{Acid Producing Solids}

The cyclone drum burning system utilizes the cooling effects of the high velocity air flow to cool the walls of the combustion drum, so no refractories are needed in the burning chamber. If acid producing waste is being burned, the combustion drum, the upper combustion chamber (sealed to the top of the drum and used to inject combustion air and exhaust off-gas), and the off-gas header presents a large expanse of metal that is subject to corrosion damage. At operating temperatures of $800-1000^{\circ} \mathrm{C}$, the acid gaes are extremely corrosive, and under batch operating conditions, temperature cycling may allow condensation of acids in these area. In addition, there have been problems of acid corrosion damage in the deluge tank and transfer pipe connecting the deluge tank and venturi scrubber.

Volatile and Low Melting Solids

Volatile solids will volatilze at the operating temperature of this system. The refractory lined flue gas header could be subject to lead corrosion.

\section{Liquid Waste Capabilities}

Only limited burning of clean kerosene has been conducted at Mound. Results with kerosene were encouraging, but further testing with various organic liquids is needed to determine the overall capabilities of the system.

\section{Capacity}

Unknown. 
The burning of corrosive liquids does not seem advisable in this system considering the corrosion problems already experienced with solid wastes.

Aqueous Wastes

There are no provisions for aqueous waste disposal at the Mound Facility. Aqueous wastes would have to be fed with other solid or liquid combustibles, and the system is not equipped for this at present. Small amounts of a dioxane-water mixture have been burned in tests with scintillation vials.

\section{Radioactive Waste Capabilities}

\section{Design Potential}

The cyclone incinerator was designed for volume reduction of TRU wastes at DOE facilities and waste burial sites. There are no provisions for burning wastes of higher TRU concentrations than can be safely stored in a $210-\ell$ steel drum.

\section{Nuclear Safety}

The system is not geometrically safe, so nuclear safety must be maintained by administrative means if fissile materials are present in the waste. The system as installed does not incorporate the necessary criticality features for processing glove box generated waste with higher levels of fissile material. Some fly ash is transferred to the scrubbing system by the off-gas stream, but there is no positive ash removal system until the unit is shut down. Ash is then removed from the drum by vacuum . transfer. 
The system is hand operated, but the basic principle of the process eliminates much of the waste handling. If the unit is batch operated, a barrel of waste is attached to the upper combustion chamber and ignited. No dumping, sorting, or size reduction is necessary. No other contact operation is needed until the drum is removed for vacuum ash removal.

\section{Actinide Recovery}

The high operating temperature $\left(1100-1300^{\circ} \mathrm{C}\right)$ will produce refractory oxides that are less soluble than those from lower temperature processes. The process cannot handle large amounts of fissile isotopes at present, however, because of nuclear safety considerations.

\section{Major Advantages}

- Simplicity of design.

- Low capital cost.

- No waste pretreatment (with batch operation).

- Low waste handling requirements.

\section{Major Disadvantages}

- Subject to acid corrosion

- High particulate loading in off-gas stream.

- Relatively high carbon content in ash.

- Will accommodate only low levels of fissile materials.

\section{Potential Application}

The cyclone incinerator has very distinct advantages and disadvantages that make the correct application especially important. Equipment corrosion has been a problem, and will continue to be troublesome when burning 
acid producing wastes. However, the simplicity and modular construction of the system are conducive to easy replacement of relatively inexpensive equipment if necessary. The lack of criticality protections, such as continuous ash removal, etc., would appear to make the burning of LLW desirable. Because of simplicity, low waste handling requirements, the system seems especially adaptable to remote operation. However, the unit is presently installed in a glove box type of operation and no remote operating and maintenance techniques have been tested. Incineration of LLW at a power plant would appear to be a good application for this process.

\subsubsection{Electric Controlled Air (SRL) ${ }^{12}, 15$}

\section{Solid Waste Capabilities}

The SRL unit is designed for the incineration of small quantities of solid waste consisting of cellulose, PVC plastic, polyetylene plastic, and rubber.

\section{Capacity}

Design capacity is $5 \mathrm{~kg} / \mathrm{hr}$.

\section{Waste Size}

Waste is packaged in 250-gram batches in 4-in. by 9-in. 1ong paper bags prior to feeding. Any waste larger than the bag size has to be shredded before packaging.

Noncombustibles

Small noncombustible items could be tolerated by the system; however, noncombustibles would have to be sorted out of wastes that require shredding for size reduction. 


\section{Moisture Content}

This process should accept relatively wet waste since it does not rely on waste heat value to maintain operating temperature. Moist waste will, of course, decrease capacity.

\section{Acid producing Waste}

The incinerator is completely constructed of prefabricated ceramic components, which consist of a horizontal primary combustion chamber and nine vertical alumina afterburner tubes. This equipment should be impervious to acid attack at the 700 to $1000^{\circ} \mathrm{C}$ operating temperature. 0ff-gas leaving the afterburner tubes passes into a three-stage scrubbing system, which removes particulate and neutralizes acid gases.

\section{Volatile and Low Melting Solids}

Operating temperatures of this unit are conducive to the volatilization of applicable metals. The ceramic components will be subject to degradation if wastes with high lead content are consistently burned.

\section{Liquid Waste Capabilities}

There are no provisions for the burning of organic or aqueous liquids in this sytem; the unit was specifically designed for solid waste.

\section{Radioactive Waste Capabilities}

\section{Design Potential}

The SRL unit has been designed for burning waste contaminated up to $10^{5}$ times the nominal $10 \mathrm{nCi} / \mathrm{g}$ threshold value or about $10^{-2}$ grams radio. active isotopes/gram of waste. 


\section{Nuclear Safety}

The incinerator is small and will not accommodate large quantities of wastes, but primary criticality control will be administrative. There is no positive ash removal system; however, most ash will be transported to an ash pit (at the outlet of the primary combustion chamber) by the addition of waste. Some retention of fly ash must be expected in the series of afterburner tubes.

\section{Degree of Automation}

The planned incineration system will be hand operated. Waste will be presorted and shredded, if necessary, for packaging in the 4-in. by 9-in. feed bags. Ash must be periodically removed from the ash retention chamber for storage or immobilization. The unit will require periodic complete cleanouts to prevent any buildup of fissile isotopes.

\section{Actinide Recovery}

The unit will operate at $1000^{\circ} \mathrm{C}$, which is sufficient to form refractory oxides that are difficult to dissolve in recovery operations.

\section{Major Advantages}

- Electrically heated primary chamber may improve operational safety.

- Limited airflow in the primary chamber reduces ash entrainment.

\section{Major Disadvantages}

- No positive ash removal system during operation.

- Retention of fly ash in afterburner tubes. 


\section{Potential Applications}

Many of the basic concepts for the electric air incinerator were derived from the Windscale, England incinerator. The English incinerator has burned high level TRU type waste for a number of years. The SRL unit was specifically designed for the same purpose. The electric heating was chosen over auxiliary fuels such as oil or gas to insure a high degree of safety in the production mode1. It appears that this unit will be used to its best advantage in burning a relatively high level, low volume TRU waste. Fly ash buildup could prove troublesome in the afterburner tubes. This and waste prepackaging requirements would present problems in a remote operated version of the process. In addition, the presence of lead in the waste could contribute to erosion of the all-ceramic unit.

\subsubsection{Fluidized Bed (RFP) 16,17}

\section{Solid Waste Capabilities}

Fluidized bed incineration has been demonstrated with a large variety of waste solids that include paper, polyethylene, PVC plastics, latex rubber gloves, wood, leaded rubber gloves, organic resins, cartridge filters, waste chemicals, HEPA filters, and protective clothing.

\section{Capacity}

Based on a heat release of $1,500,000 \mathrm{Btu} / \mathrm{hr}$, the demonstration unit will burn approximately $82 \mathrm{~kg} / \mathrm{hr}$ of average solid waste.

\section{Waste Size}

Waste is double shredded to achieve a 1/4- to 1-in. size for continuous feeding via a screw conveyor. The primary shredder will accept waste up to a $2-\mathrm{ft}^{3}$ size for initial shredding. 
Large noncombustibles must be removed prior to shredding. An air classification system between the two shredders removes small noncombustibles, and very fine noncombustibles are automatically removed from the fluidized bed by means of a screw conveyor.

\section{Moisture Content}

The unit will tolerate relatively wet solids. Materials containing 50 weight percent moisture have been burned.

\section{Acid Producing Solids}

Acids produced during the decomposition of materials such as PVC plastic are neutralized as they are formed in the bed of fluidized sodium carbonate granules.

Volatile Solids

The low operating temperature of $550^{\circ} \mathrm{C}$ reduces the potential of volatilizing materials such as lead, while the sodium carbonate bed prevents the formtion of volatile lead, iron, and phosphorous chloride compounds.

\section{Liquid Waste Capabilities}

The process has burned naptha solvents, trichloroethylene, tributyl phosphate, waste chemicals, and waste oils. It has also been demonstrated at a 99.9999\% efficiency for combustion of Polychlorinated Byphenyls (PCB)solvent mixture.

\section{Capacity}

Based on a heat release of $1,500,000 \mathrm{Btu} / \mathrm{hr}$, the demonsration unit will burn about $50 \mathrm{l} / \mathrm{hr}$ of combustible liquids. 
Acid Producing Liquids

Acids produced by burning materials such as chlorinated solvents are neutralized in the bed of sodium carbonate.

\section{Aqueous Liquids}

The system will accept moderate amounts of aqueous acid or basic wastes with the addition of an auxiliary fuel such as methanol or kerosene. No provisions have been made on the present unit for processing waste slurries.

\section{Radioactive Waste Capabilities}

\section{Design Potential}

The present unit was designed for incineration of TRU and LLW wastes contaminated with ${ }^{239} \mathrm{Pu}$ in concentrations up to $10^{-3}$ grams/gram of waste.

\section{Nuclear Safety}

The unit is not geometrically safe; consequently, administrative control is necessary for nuclear safety. However, since the system does not require an aqueous scrubbing system the potential for nuclear criticality is greatly reduced. Waste is fed continuously and ash is continuously removed from the off-gas stream by cyclone separation and sintered metal filtration. Ash is continuously removed from the system by a screw conveyor.

\section{Degree of Automation}

The equipment is housed in a canyon arrangement for alpha containment. . Waste barrels must be opened and attached to a glove box. Once the drum is attached, the waste is emptied, sorted, and fed into the primary shredder 
by glove box contact operation. Incineraton operation is monitored and controlled from a separate control room. No other hand operation is required except the removal and replacement of ash drums that are automatically filled by a screw conveyor.

\section{Actinide Recovery}

Low temperature operation produces low fired ash amenable to recovery operations. Spiked amounts of plutonium oxide and plutonium nitrate were successfully recovered from incinerator ash by a water wash and nitric acid leaching technique.

\section{Major Advantages}

- In situ neutralization of acids.

- Low temperature combustion that el iminates refractories.

- Agitation of waste in fluidized bed during combustion.

- Dry off-gas system.

- Continuous ash removal.

- Low fired ash for actinide recovery.

- Designed to process high levels of fissile content waste.

\section{Major Disadvantages}

- Small feed size requires double waste shredding.

- Catalyst usage for off-gas afterburning.

- Some insoluble catalyst in ash.

\section{Potential Applications}

The fluidized bed has successfully burned a large variety of waste solids and liquids. The in situ neutralization of acids makes the process . a leading candidate for waste streams containing large quantities of acid producing solids or liquids. The system has proven especially good for 
liquids burning, and the waste shredding system could be eliminated for this application. Ion exchange resins could al so be burned without pretreatment. The system should produce low fired oxides amenable to actinide recovery applications. The process can be operated on a small scale in geometrically safe vessels for actinide recovery operations or on larger scales for high throughput of TRU wastes. Easy unit replacement and the lack of high maintenance refractories makes the process a good candidate for remoting. Since the process is installed in a canyon, some remote operating techniques have been tested.

\subsubsection{Molten Salt (RI) ${ }^{18,19}$}

\section{Solid Waste Capabilities}

The molten salt incineration process was developed by Rockwell International for burning various radioactive wastes. The system has burned paper, polyethylene, PVC plastic, latex rubber gloves, organic ion exchange resin, and leaded Hypalon glove box gloves, film, and various waste chemicals.

\section{Capacity}

The process has been demonstrated on a bench scale of $0.2 \mathrm{~kg} / \mathrm{hr}$ and a pilot scale of $50 \mathrm{~kg} / \mathrm{hr}$.

\section{Waste Size}

Waste is pneumatically injected into the molten salt bed. In order to accomplish this, the particle size of the waste must be reduced to approximately $1 / 2$ in. A hammermill was used for waste size reduction at RI, but double shredding should offer comparable sizing capability. 


\section{Noncombustibles}

Waste is sorted prior to shredding to remove noncombustibles that would damage a shredder. Small tramp metal will slowly be oxidized in the molten sodium carbonate, but other insoluble noncombustibles will slowly build up in the molten salt. This would necessitate a complete cleanout eventually.

\section{Moisture Content}

The molten salt process will not tolerate any free water in waste feed; consequently, wastes must be relatively dry or predried prior to processing. In addition, moist waste would be difficult to pneumatically transfer into the incinerator.

\section{Acid Producing Solids}

Waste is combusted in a bed of molten sodium carbonate and sodium sulfate, which immediately neutralize any acids formed during combustion.

\section{Volatile or Low Melting Solids}

Sodium chloride, which is formed in the molten salt bed, tends to volatilze at the operating temperature of $800-900^{\circ} \mathrm{C}$, and must be removed in the off-gas cleanup system. Lead, which does not volatilize in this system, reduces to metal that forms a pool at the bottom of the salt bed.

\section{Liquid Waste Capabilities}

The system has been tested with organic liquids that include kerosene, tributylphosphate, and various pesticides. The process has been proposed for any organic waste, including high-sulphur oils, etc. 
Capacity

Unknown.

Acid Producing Liquids

The process is designed to neutralize acids formed during the combustion of either solid or liquid wastes. Wastes are injected beneath the surface of the molten salt to insure the neutralization of acid gases before they reach the surface of the melt.

\section{Aqueous Liquids}

The system will not tolerate any free water; consequently, no aqueous wastes could be processed by this method.

\section{Radioactive Waste Capabilities}

\section{Design Potential}

A $45-\mathrm{kg} / \mathrm{hr}$ system was designed for processing buried wastes at INEL. A molten salt system has been designed to process wastes with plutonium in concentrations up to $8.8 \times 10^{-4}$ gram Pu/gram waste, and could be scaled down to a size that would be geometrically safe for much higher Pu concentrations.

\section{Nuclear Safety}

The process could be operated on a small scale with geometrically safe equipment; however, larger capacities such a the $45-\mathrm{kg} / \mathrm{hr}$ unit would. require administrative control for nuclear safety. There is no means of continuous ash removal, but ash would be removed in the periodic drainings . of spent salt. Tests have shown that 99 percent of the plutonium in waste is retained in the melt. 


\section{Degree of Automation}

The process has been essentially hand operated in tests thus far. Waste must be finely shredded for pneumatic feeding; consequently, wastes must be sorted to remove noncombustibles that would damage shredding equipment. Draining of spent salt has also been conducted as a hand operation thus far. Tests with $\mathrm{Pu}$ contaminated waste were conducted in a glove box that necessitated bagout procedures for salt, wastes, etc.

\section{Actinide Recovery}

A1 though the system operates at a temperature of $800-1000^{\circ} \mathrm{C}$, it produces a soluble form of plutonium for recovery. The actinides and other metallic oxides are separated from the spent salt by a water wash procedure in which the salt is dissolved and the oxides remain as an insoluble residue. Rockwell has reported Pu recovery rates of 90 to 98 percent in nitric and hydrochloric acid leaching of the residues.

\section{Major Advantages}

- In situ neutralization of acids.

- Agitation of waste in molten salt bed during combustion.

- Tolerates some noncombustibles such as metal and glass.

- Automatic separation of lead from salt-ash residue.

\section{Major Disadvantages}

- Small feed size requires extensive waste shredding.

- Sodium chloride entrainment in off-gas.

- Will not tolerate free water in waste. 


\section{Potential Applications}

This process features in situ neutralization of acids produced during combustion of PVC, etc. It will tolerate most forms of nuclear wastes, including leaded dry box gloves and other lead bearing wastes. Lead from wastes forms a pool at the bottom of the salt bed that can be drained separately from the salt itself. These two features would be valuable in burning wastes containing high concentrations of acid producing wastes and/or lead bearing wastes. Wet solids and aqueous liquids cannot be processed by this system, and care must be exercised to avoid accidental feeding of wet materials. On a small scale, the process could be designed critically safe for high levels of TRU elements. Maintenance of refractories and other high temperature valves and equipment might prove to be difficult under remote operating conditions.

\subsubsection{Rotary Kiln (RFP) ${ }^{8}$}

\section{Solid Waste Capabilities}

The rotary kiln incinerator at RFP has not been tested for burning nuclear wastes as yet; it is scheduled for startup in 1981. It was designed to burn cellulose, polyethylene and PVC plastics, rubber, organic resins, wood, and polypropylene cartridge filters.

\section{Capacity}

Design capacity is $41 \mathrm{~kg} / \mathrm{hr}$.

\section{Waste Size}

The rotary kiln is $6 \mathrm{ft}$ in diameter and could burn quite large size waste, but the ram feeder will accept waste packages of only approximately $1 \mathrm{ft}^{3}$ in size. 
Noncombustibles

The kiln will tolerate any amount of noncombustibles as long as they fall within the size limitations of the ram feeder and the ash discharge port.

Moisture Content

The system should accept relatively wet solids, since the unit is oil fired and the waste undergoes a tumbling action in the rotating kiln.

Acid Producing Solids

The unit is refractory lined and has a minimal amount of metal exposed to the corrosive environment and elevated operating temperatures. However, some acid corrosion of the steel outer tube or head end feeding equipment can be expected. A caustic scrubbing system will neutralize acids in the off-gas.

Volatile or Low Melting Solids

The refractory lined kiln is subject to degradation by low melting and glass forming materials such as lead. Some materials will volatilize at the operating temperature of 800 to $1000^{\circ} \mathrm{C}$.

\section{Liquid Capabilities}

The rotary kiln is equipped to feed both organic and aqueous waste liquids. Provisions have been made to continuously monitor temperatures and detect the presence of flame during liquids incineration.

\section{Capacity}

Design capacity is approximately $135 \mathrm{~kg} / \mathrm{hr}$ of various organic liquid mixtures. 


\section{Acid Producing Liquids}

Acid producing liquids could present corrosion problems in atomizing nozzles and other metal components in the system.

\section{Aqueous Liquids}

The RFP unit is equipped to inject aqueous laboratory wastes. Some wastes may contain glass formers, however, that could be damaging to refractories in the kiln and afterburner.

\section{Radioactive Waste Capabilities}

\section{Design Potential}

The kiln was designed for burning line generated, high level TRU waste that will be processed for plutonium recovery.

\section{Nuclear Safety}

The RFP unit has been approved for incineration of high level TRU waste. Ash removal is continuous and automatic by action of the inclined, rotary kiln. The components of the caustic scrubbing system are either critically safe by dimension or filled with borosilicate Raschig rings for nuclear poisoning.

\section{Degree of Automation}

Waste must be packaged in containers suitable for ram feeding to the kiln; no other pretreatment is required. Operation of the incinerator will be monitored and controlled from a separate room. Ash automatically falls on a vibrating screen that separates the ash from noncombustibles (tramp . metal). Most of the waste will be transferred to the incinerator sorting glove box by an in-line transfer system, and ash and noncombustibles will 
be transported out by the same system. Contact handling will be primarily 1 imited to the waste sorting operation.

\section{Actinide Recovery}

The unit is designed to burn wastes containing recoverable amounts of plutonium, but the $\mathrm{planned}$ operating temperature of $800-1000^{\circ} \mathrm{C}$ will produce refractory oxides.

\section{Major Advantages}

- Positive, automatic ash removal.

- Little waste pretreatment requirements.

- Tumbling action of waste during combustion.

- Accepts noncombustibles.

- Designed for processing high levels of fissile content waste.

\section{Major Disadvantages}

Rotary seal maintenance.

\section{Potential Applications}

The RFP unit will be utilized for burning wastes containing recoverable amounts of plutonium. The rotary kiln was selected for this application because it provides a positive, continuous removal of ash with a minimum retention of residues in the combustion chambers. It will tolerate and remove from the system any percentage of noncombustibles that may be charged; consequently, it would be a good candidate for waste streams containing large amounts of noncombustibles. It would be desirable to avoid wastes of high lead content to increase the refractory life of the unit. The system at RFP is relatively automatic, with little waste handling except to load the ram feeder. If seal and bearing maintenance requirements do not prove to be excessive, the rotary $k i$ in should be a 
strong candidate for remote operating applications. The unit at RFP is installed in a canyon type system where remote operation will be employed.

\subsubsection{Slagging Pyrolysis (INEL) ${ }^{20}, 21$}

\section{Solid Waste Capabilities}

An Andco-Torrax incinerator is being considered for burning wastes retrievably stored at INEL. The unit under consideration has not been utilized in a nuclear waste application as yet. There is a version of this incinerator being demonstrated for burning municipal refuse in Luxembourg, Belgium. The INEL unit will be designed to accept all kinds of combustibles, most types of noncombustibles, and contaminated soil.

\section{Capacity}

The proposed unit will process $850 \mathrm{~kg} / \mathrm{hr}$.

\section{Waste Size}

There is no size limit for incoming waste except that imposed by the throat of the incinerator, which is $1.4 \mathrm{~m}$ in diameter. A rough sizing to approximately $1 / 2 \mathrm{~m}$ in diameter has been proposed for the INEL installation.

Noncombustibles

All types of noncombustibles, including soil, will be accepted by this process with the only limitation being the size restraints of the waste throat. 
Moisture Content

The process will accept very wet materials because the wastes must pass through a drying zone as they move down the vertical shaft toward the lower pyrolysis and combustion zones.

\section{Acid Producing Wastes}

Acids produced by decomposition of wastes may cause corrosion damage to metal components. In situ neutralization of acids may be accomplished if sodium carbonate is added to wastes that contain PVC plastic. Any excess of sodium carbonate would be incorporated into the slag product..

\section{Volatile or Low Melting Wastes}

The high operating temperatures $\left(1650^{\circ} \mathrm{C}\right)$ in the combustion/melting zone will volatilize or melt most metals contained in the wastes. The presence of large quantities of lead in wastes buried at INEL could cause deposition problems and refractory degradation in this particular application.

\section{Liquid Capabilities}

The INEL incinerator is being designed primarily for stored solid wastes; however, it appears that the system would tolerate a considerable amount of either organic or aqueous liquid wastes along with combustible solids and/or auxiliary fuel.

\section{Capacity}

Unknown. 


\section{Acid Producing Liquids}

Incineration of acid producing 1 iquids such as $\mathrm{CCl}_{4}$ would present a good opportunity for corrosion of metal components unless a sufficient amount of sodium carbonate was also fed for in situ neutralization.

\section{Aqueous Liquids}

A moderate amount of aqueous wastes can be tolerated along with solids or auxiliary fuels.

\section{Radioactive Waste Capabilities}

\section{Design Potential}

The proposed unit is being designed to burn the majority of the wastes retrievably stored at INEL. Some waste sorting will be required to identify drums containing more than 200 grams of plutonium. Drums that contain greater than 200 grams will be set aside for other processing; all other waste is acceptable for the slagging pyrolysis unit. The unit will require a large amount of additives for supplemental fuel (coal and wood chips) and product slag formers (soil).

\section{Nuclear Safety}

Because of the large size of the equiment and the great throughput, nuclear safety must be maintained by strictly administrative methods.

\section{Degree of Automation}

Waste will be manually sorted to determine the plutonium content. When high level waste (in excess of 200 gram Pu per drum) is identified, it will be removed from the feed stream. Intact drums will probably be cut open and fed into the vertical drying shaft. Operation and slag removal 
will be automatic, and no other hand operations will be required other than disposal of the slag residue.

\section{Actinide Recovery}

The basalt-type slag residue produced by this process would be very difficult to process for actinide element recovery. The high fired residue will be insoluble in most acid leach processes.

\section{Major Advantages}

- Process will accept unsegregated wastes containing high percentages of noncombustibles.

- Requires very little waste sizing or pretreatment.

- Generates a stabilized residue for storage.

- Slag is continuously discharged.

- In situ neutralization of acids can be incorporated if sodium carbonate is fed with waste.

- Availabilty of commercial design.

\section{Major Disadvantages}

- Large volume of waste in the unit could cause nuclear safety concerns.

- Slag residue is unacceptable for actinide recovery.

- Volume in weight reduction will be less than other systems because of the required additives for slag formation.

\section{Potential Applications}

The only slagging pyrolysis incinerator now being considered for nuclear waste is the unit proposed for burning the INEL retrievably stored wastes. Similar units are in use for municipal incineration, where large quantities of waste are converted to a stabilized slag for discard or 
reuse. This type of application would appear to be ideal for this incinerator, since the goal is to eliminate the stored waste and produce a stabilized product in a single operation. Refractory damage may be a problem if the large quantities of lead in the buried waste is burned. Remoting of this particular unit will be difficult because of the large size equipment and refractory maintenance.

\subsection{Incineration Cost Evaluations}

The primary criteria for selection of a suitable incinerator for a given application is that the unit be able to accept the waste to be processed and produce an acceptable product within a safe operation. For a' given application several combustion processes may be able to meet the technical objectives; then the capital cost for installation of a unit and the operating cost become important decision factors. It is impossible to provide a complete cost analysis without having the application and the site where the process would be installed well defined.

In an effort to provide some cost comparison for the various processes discussed in this report, data has been assembled on the installed cost of systems funded through TWSO as well as two production units at Rocky Flats and a molten salt process which was purchased for installation at INEL. The costs obtained from each site represent the units "as installed" including design, equipment procurement, and installation direct costs. For each system the cost estimate was adjusted from the year of installation to a common basis of 1979 dollars. There is a wide variance in the degree of instrumentation provided for the units. In the case of the fluidized bed incinerator the cost includes a computer data acquisition and process control system that was installed for research purposes; but this is not required for a typical production operation. The Electric Controlled Air, Fluidized Bed and Rotary Kiln incinerators, and the Acid Digestion unit were all designed to process waste materials from glove box or canyon operations. Geometrical restrictions in the existing digester of the Acid Digestion unit increase the cost compared to that which may be 
required for processing waste containing little fissile material. Redundant scrubbing systems and geometrical size limitations employed in the off gas cleaning system for the Rocky Flats Rotary Kiln increased the cost compared to that required for non-glove box generated waste.

The installed cost for the Molten Salt system included a metal building but was not designed to accommodate high concentrations of fissile material. These two factors tended to be off setting in affecting the estimated cost. The equipment was purchased but never installed and the cost figure was based on projected installation.

The Slagging Pyrolysis Incinerator was estimated for a large $850-\mathrm{kg} / \mathrm{hr}$ unit to be installed in a new facility. A cost estimate was also obtained for a $63.6-\mathrm{kg} / \mathrm{hr}$ unit. These two costs are comparable if one uses an 0.5 power factor to scale the capacity. The cost estimates presented in this report are based on the $63.6-\mathrm{kg} / \mathrm{hr}$ unit. The capacity of these units was based on the assumed feed of TRU waste stored at INEL which contains about $30 \%$ combustible. If these units were to process combustible category waste only, it is anticipated that the capacity could double and still have sufficient additives to produce a slag product.

The Controlled Air, Agitated Hearth, and Cyclone Drum incinerators were designed to process non-glove box generated waste. Therefore, the units are less complex in terms of criticality control features which tend to reduce the installed equipment cost.

Presented in Table 3-2 are the capacity of each unit and the installed cost.

The cost was also adjusted using the 0.6 power rule to estimate the cost of each unit sized to process $45 \mathrm{~kg} / \mathrm{hr}$ of combustibles. This represented a scale-up factor of 9 for the Electric Controlled Air incinerator and a scale-down factor of 1.82 for the Fluidized Bed Incinerator. The scale factor for all other units fell within that range and each is 
TABLE 3-2

\section{INSTALLED INC INERATION CAPAC ITY \\ AND ASSOC IATED COSTS \\ IN 1979 DOLLARS}

System Capacity

$$
(\mathrm{kg} / \mathrm{hr})
$$

27

70

AH, Agitated Hearth

FBI, Fluidized 82 Bed

CAI, Controlled Air

$$
\begin{aligned}
& \text { RKI, Rotary } \\
& \text { Kiln }
\end{aligned}
$$

MS, Molten

Salt

$A D$, Acid

Digestion
EAI, Electric 5 Controlled Air

SPI, Slagging Pyrolysis
41

45

10

64

64

Installed Cost

\begin{tabular}{cc} 
Installed & $45 \mathrm{~kg} / \mathrm{hr}$ \\
Capacity & Capacity \\
$\$ 1,000,000)$ & $(\$ 1,000,000)$ \\
\hline
\end{tabular}

0.8

1.7

2.3

2.0

2.6

3.6

1.5

2.7

8.8

1.3

1.6

2.0

2.75

3.6

3.7

10.1 $\frac{\text { Installed Cost/Unit Capacity }}{\text { At Installed At } 45 \mathrm{~kg} / \mathrm{hr}}$ Capacity

$(\$ 1,000)$

$(\$ 1,000)$

29.6

24.2

$24: 3$

28.9

28.0

35.6

44.4

44.4

63.1

61.1

80.0

80.0

150.0

82.2

540.0

224.4

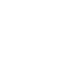


probably capable of being designed to process $45 \mathrm{~kg} / \mathrm{hr}$. Presented in Figure 3-1 are the installed capital cost per unit throughput capacity relative to the combustion system capacity. The cost of the Electric Controlled Air Incinerator is shown in a special note on this figure because of its high cost. Including this in the figure would have required an unwanted compression of the vertical scale. The Electric Controlled Air Incinerator at SRP was designed to process waste with a high curie content which may be part of the reason for the high cost. Only five of the systems were designed to process high levels of fissile material: Acid Digestion, Rotary Kiln, Fluidized Bed, Electric Controlled Air, and Slagging Pyrolysis. If the Acid Digestion and the Rotary Kiln systems were designed for non-glove box generated waste (low fissile content) the cost would probably be lowered because of the less stringent geometrical size limitations. The cost of the Slagging Pyrolysis and the Electric Controlled Air would not be expected to change significantly if they were designed only for low fissile content waste. Since the Fluidized bed incinerator is a totally dry system, design of a unit to process only nonglove box generated waste or LSA waste may not result in a major cost reduction. This system has processed non-glove box generated waste with significant levels of TRU contamination, but has not been operated with glove box generated waste. It would be beneficial to verify the nuclear safety of this system by conducting tests with higher levels of fissile material content waste generated in glove box operations. The other systems were designed for processing non-glove box generated waste or LSA waste only.

To provide a more direct comparision of the capital cost of the various processes, the cost of each system has been estimated for a capacity of $45 \mathrm{~kg} / \mathrm{hr}$. This information is presented in Figure 3.2. The capital cost varies from a low of $\$ 1,100,000$ for the Cyclone Drum Incineration to a high of $\$ 10,500,000$ for the Electric Air Incineration System. Because of the unwanted compression of the vertical scale, the costs for - the slagging pyrolysis unit and the Electric Controlled Air incinerator are included in a special note. 
FIGURE 3-1

CAPITOL INVESTMENT PER UNIT CAPACITY FOR INSTALLED COMBUSTION SYSTEM

IN 1979 DOLLARS

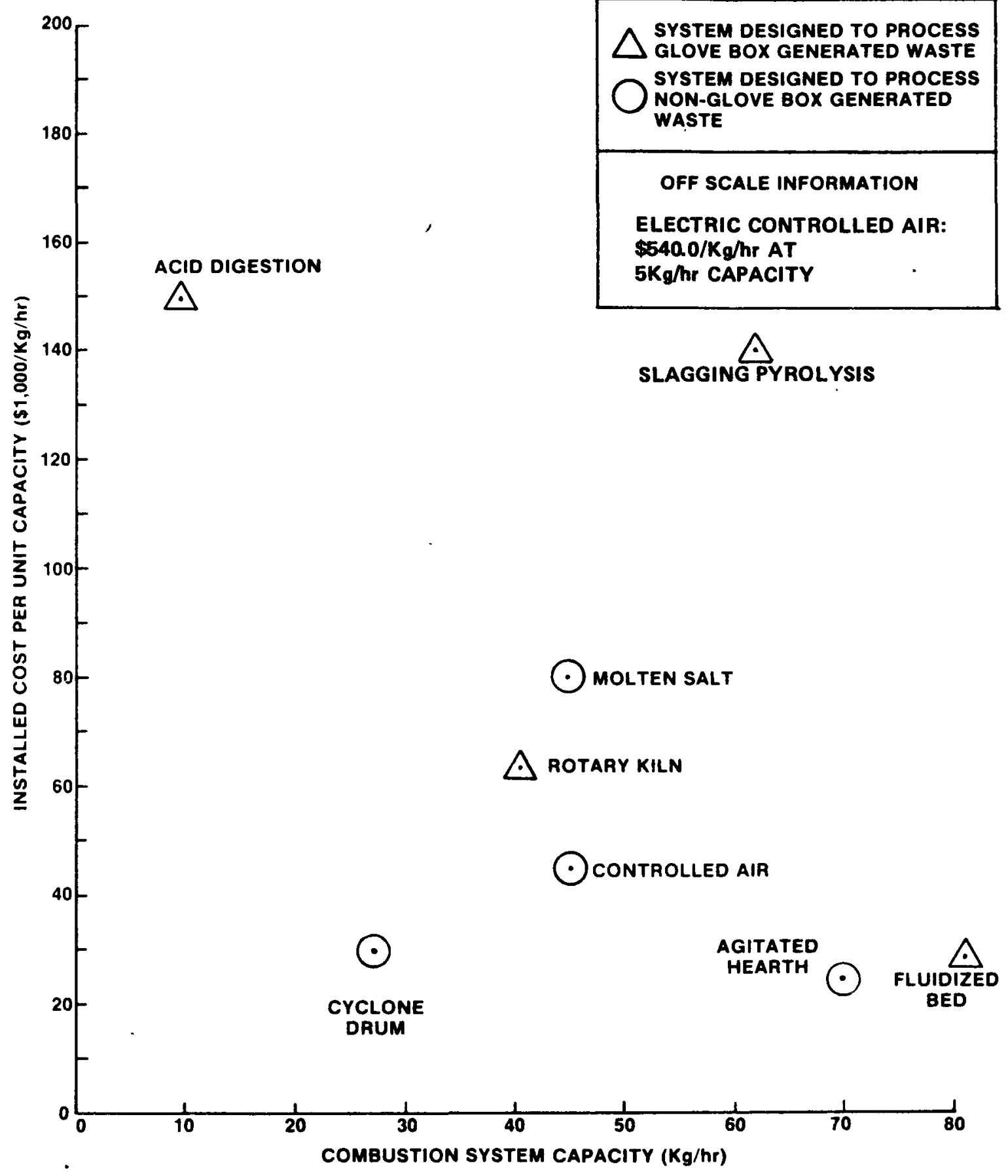


An evaluation of the operating costs for each system is needed but is not available for this report. Two factors which would have a major impact on the operating costs are the operating labor and the maintenance requirements. If one assumes that these two factors do not vary greatly among the various systems presented (which may be overly simplistic), then the capital costs presented could be used as an economic guide for selecting a suitable system for specific applications. 
FIGURE 3-2

INSTALLED COST OF EACH

COMBUSTION SYSTEM ESTIMATED

FOR A CAPACITY OF $45 \mathrm{Kg} / \mathrm{hr}$

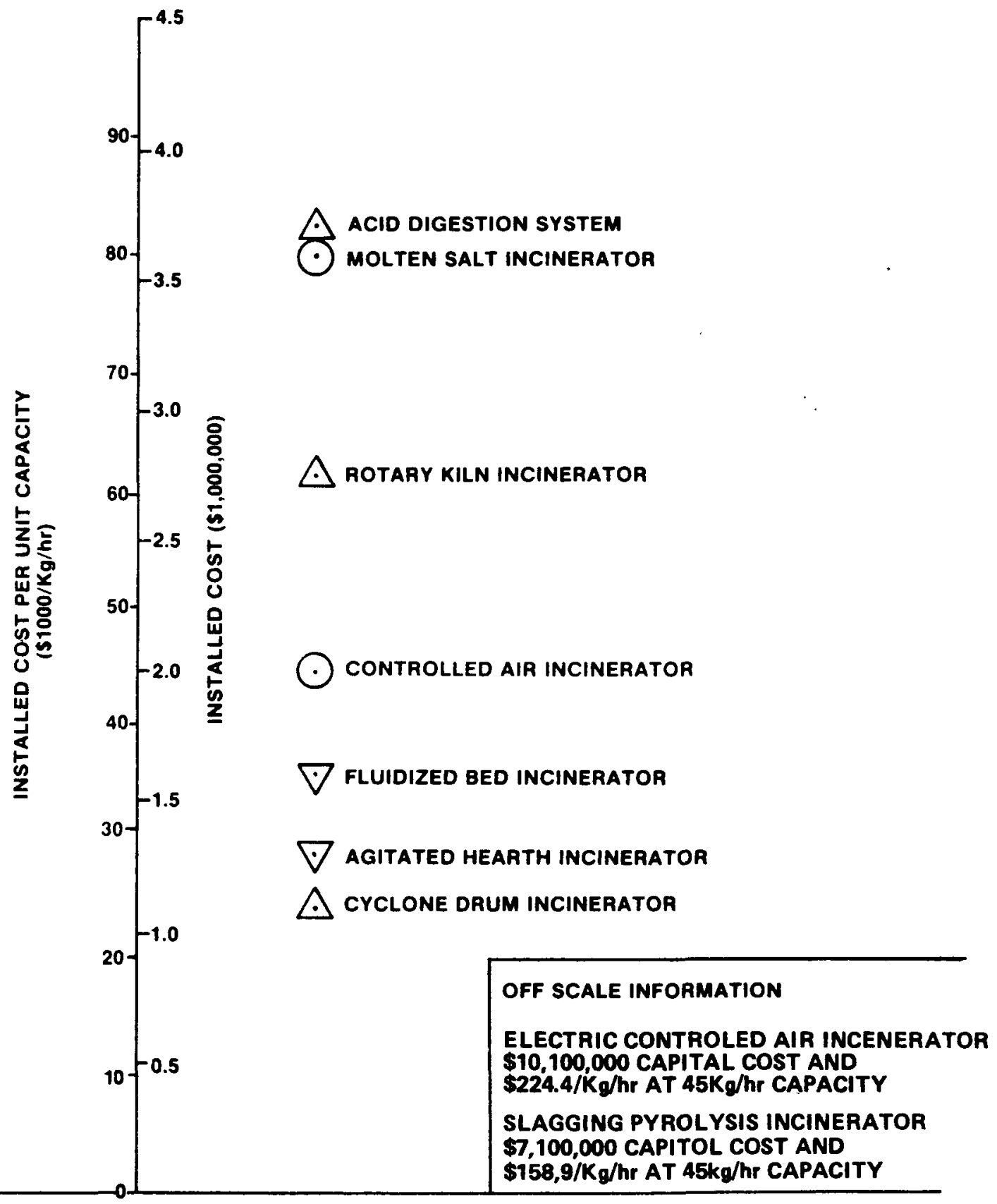

$\nabla$ COST ESTIMATE SCALED DOWN FROM A HIGHER CAPACITY UNIT

$\triangle$ COST ESTIMATE SCALED UP FROM A LOWER CAPACITY UNIT

Coost estimate based on existing UNIT WITH 45Kg/hr CAPACITY 


\subsection{INC INERATOR SELECTION}

\subsection{Selection Criteria}

The various nuclear waste incinerators now under development have all been evaluated by various people and committees ${ }^{2}$ in regard to their safety, effectiveness, flexibility, operability, cost, developmental stage, etc. However, it is difficult to evaluate and rate incinerators in these areas without consideration of potential applications. The Goldberg Committee noted that each of the developmental units had been designed for a specific use and concluded that no one system would be successful in all applications. All of the new design incinerators have been determined to be safe, effective, and operable for at least one application; this does not necessarily signify that they would perform as well in other applications. Consequently, the choice of an incinerator must be based upon the application as well as the general capabilities of the unit.

The Goldberg Committee cited the following list of selection criteria:

Effectiveness

Elimination of combustibles

Volume reduction

Weight reduction

Secondary waste generation

off-gas composition

Availability

Maintainability

Flexibility

Waste compounds handled

Throughput

Resource use

Compatibility with downstream processes

Product characteristics

Operability

Feed preparation requirements 
A study by the FMC Corporation for the "Selection of waste treatment process for retrieved TRU waste at Idaho National Engineering Laboratory" 20 considered many different criteria for process comparison. They stated that the process must:

Render the waste inert Immobilize the residue Prepare waste to meet WIPP criteria Process at least 300,000 cubic feet of waste per year Input unsegregated waste

Be operating full-scale by 1987

Have provision for emergency power Be maintainable Be a safe operation in terms of criticality, containment, radiation, exposure, and DOE and EPA exhaust gas requirements

and that the process should:

Maximize process simplicity

Minimize number of process parameters requiring control

Minimize time to maintain

Minimize routine maintenance

Maximize mean time between failures

Minimize processing (operating) cost

Minimize capital investment

Minimize engineering development time

Minimize engineering development cost

Minimize engineering development risk

Minimize radiation exposure of operating personnel

Minimize plutonium holdup or entrapment within processing system

Minimize particulate load on off-gas system

Maximize capability for remote operation

Maximize volume reduction

Minimize generation of additional waste during process

Minimize use of additional fuel during the process 

Minimize startup problems
Minimize shutdown problems
Minimize leach rate of output residue
Minimize production of toxic gases during processing
Minimize input waste sizing requirements

It is evident that each use will have his own set of process selection criteria. Most of these criteria will apply to selection of an incinerator for any application; but applicability to radwaste mixtures and effects of radioactivity are of special interest to radwaste applications. These factors which are of special importance to radwaste are discussed below.

In this report and attempt will be made to establish some general guidelines for incinerator selection based on application or waste types to be processed. A breakdown of physical and chemical characteristics and the type and levels of radioactivity will provide a profile of each waste that will be relevant to incinerator choice. The various incinerators can then be analyzed for compatibility with the wastes of interest. Some of the more important waste properties are listed below.

\section{Physical Properties}

Solid Waste

Material Content

Size

Noncombustible Content

Moisture Content

Amounts to Process

\section{Liquid Waste}

Amounts to Process 


\title{
Chemical Properties
}

Solid Waste

Composition

Acid Potential

Volatility Potential

Explosion Potential

Heat Value

\section{$\underline{\text { Liquids }}$}

\author{
Heat Value \\ Water Content \\ Solids Content \\ Acid Potential \\ Explosion Potential
}

\section{Radioactivity}

Radioactive elements present

Fissile isotopes present

Type of radiation - alpha, beta, gamma, neutron

Levels of radiation

Contact or remote operation

Actinide recovery

The properties listed intentionally disregard the source or present state (fresh generation, stored, buried, etc.) of the waste, since this information is not pertinent to the incineration process. The source and state of waste may become important in special instances if they are an indication of specific physical or chemical problems, or unusual quantities or mixtures. While an incinerator is occasionally needed to burn a large variety of wastes (such as the materials stored and buried at INEL), most 
incinerators are needed for a much more specific application. In these instances, the selection of an incinerator will be based on the capability to burn one specific waste or a limited group of wastes. Although a unit may be ideal for one waste, it may possess an inherent feature that renders it completely unacceptable for other specific wastes. Consequently, consideration of the form of the wastes to be burned may quickly narrow the choice of acceptable incinerators.

Examples of problems, caused by specific wastes, which must be considered in incinerator selection are given below. Past incineration operations have proven that administrative control is often inadequate to prevent the addition of noncombustibles to combustible waste streams. The presence of noncombustibles is a problem that must be provided for in nearly all applications. The chemical composition of the waste materials also greatly affects incinerator operation, maintenance requirements, and equipment 1 ife. The presence of acids, acid producing plastics, explosive materials, and volatile materials are some of the more troublesome chemical problems of nuclear wastes. Explosive materials must be sorted out of general plant wastes for special processing procedures. In situ neutralization of acids is provided by the fluidized bed and the molten salt incinerators, but other units that rely on caustic off-gas scrubbing may experience corrosion to head end equipment when burning acid producing wastes. The acid digestion system, of course, is resistant to acids but its glass lined equipment is subject to damage by fluorinated wastes. Materials that volatilize and later plate out in off-gas systems produce problems in most systems. Lead, which is very prevalent in radwastes, is particularly troublesome because it forms glassy compounds that attack and severely damage refractory linings. All of the detrimental physical and chemical characteristics of each radwaste must be carefully considered before an incinerator is chosen.

The type and level of radioactivity of the waste must also be considered when selecting an incinerator, since this affects the needs for criticality control and for shielding or remoting. Alpha contaminated 
wastes have been incinerated at quite high levels of activity without remote operation. With shielding designed into the containment system, operating personnel can be adequately protected while operating the equipment. When higher quantities of beta-gamma emitting isotopes are present in the waste, however, remote operation and maintenance become a necessity. If this is the case, the potential user must not only consider the types of waste an incinerator will burn but also whether or not the unit is amenable to remote operation. Incinerators have been evaluated for remote operation, and some appear more adaptable in this regard than others. The truth of the matter is, however, that no incinerator has ever been completely remotely operated and maintained, so no operating history or data is really available in this area.

Nuclear safety is directly affected by the radioactivity levels of the waste. If large quantities of fissile isotopes are present in waste, steps must be taken to guard against a criticality incident taking place as materials are concentrated during incineration. The incinerator must either be geometrically safe in dimensions or the input and output of fissile materials must be stringently controlled. Only the acid digestion system is designed in geometrically favorable dimensions; all other units must rely on some form of administrative control for criticality protection. Other considerations such as moderation, reflection, and nuclear poisoning are also important. Where the acid digestion unit is an aqueous process confined to critically safe dimensions, the other processes intentionally maintain an entirely dry combustion area to avoid the affects of liquid moderation or reflection. When liquids are burned in these units, care must be exercised to maintain a minimum operating temperature to insure gasification and/or combustion of the materials. Incinerators with aqueous off-gas scrubbing systems must be designed with critically safe dimension scrubbers or scrubbers that incorporate nuclear poisoning devices such as boron glass Raschig rings.

Absorption of radioactive materials into the system (especially refractories) is very undesirable from a nuclear safety standpoint, as well 
as contributing to increased radiation exposure to operating personnel. Refractories that have absorbed radioactive materials constitute a secondary waste when they are routinely replaced.

\subsection{Suggested Incinerators for Radwaste Applications}

One way to determine the potential uses of specific incinerators is to categorize the applications and evaluate each combustion unit with respect to its ability to process the waste materials (which would be) typical to that application. The TRU waste and Low Level waste applications are presented in Figures $4-1$ and 4-2, respectively.

Incinerators suggested for each application are listed in the figures and discussed below. The purpose of incinerating TRU waste can be divided into three general objectives: (1) Burning combustible materials to produce an ash or residue which could be subjected to chemical treatment for removal and recovery of transuranic elements; (2) Processing of combustible material to produce ash or residue which will be converted to an immobilized product form; and (3) Processing combustible waste with the primary objective of volume reduction and elimination of the potential for gas generation under storage conditions. For the low level waste the principal objective is to reduce the volume and eliminate the hazards associated with storage, transportation, and disposal of the combustible materials.

To determine the type of incineration system which is best suited to meet the specific objectives, an accurate definition of the waste material and the operation are needed. This categorization is provided under the waste and site specific factors presented in Figures 4-1 and 4-2. It is not intended that this categorization provide a complete breakdown of waste compositions; rather, only the major factors relevant to waste composition or site operation are considered. The waste and site specific factors will - be discussed in the next section of this report along with the features of the various incinerator systems in an attempt to define the most suitable systems for each application. 
TRU WASTE INCINERATION SELECTION MATRIX

OBJECTIVE OF

UTILIZING

INCINERATION

WASTE AND SITE SPECIFIC FACTOR

APPLICABLE

INCINERATION

SYSTEMS

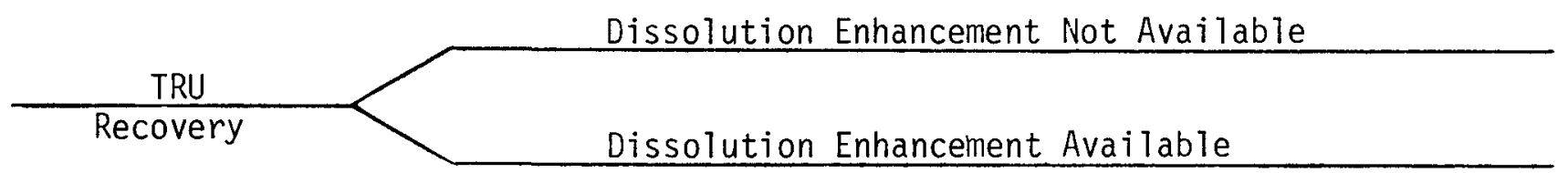

$A D, F B I, M S$

$\mathrm{FBI}, A D, R K I, E A I$

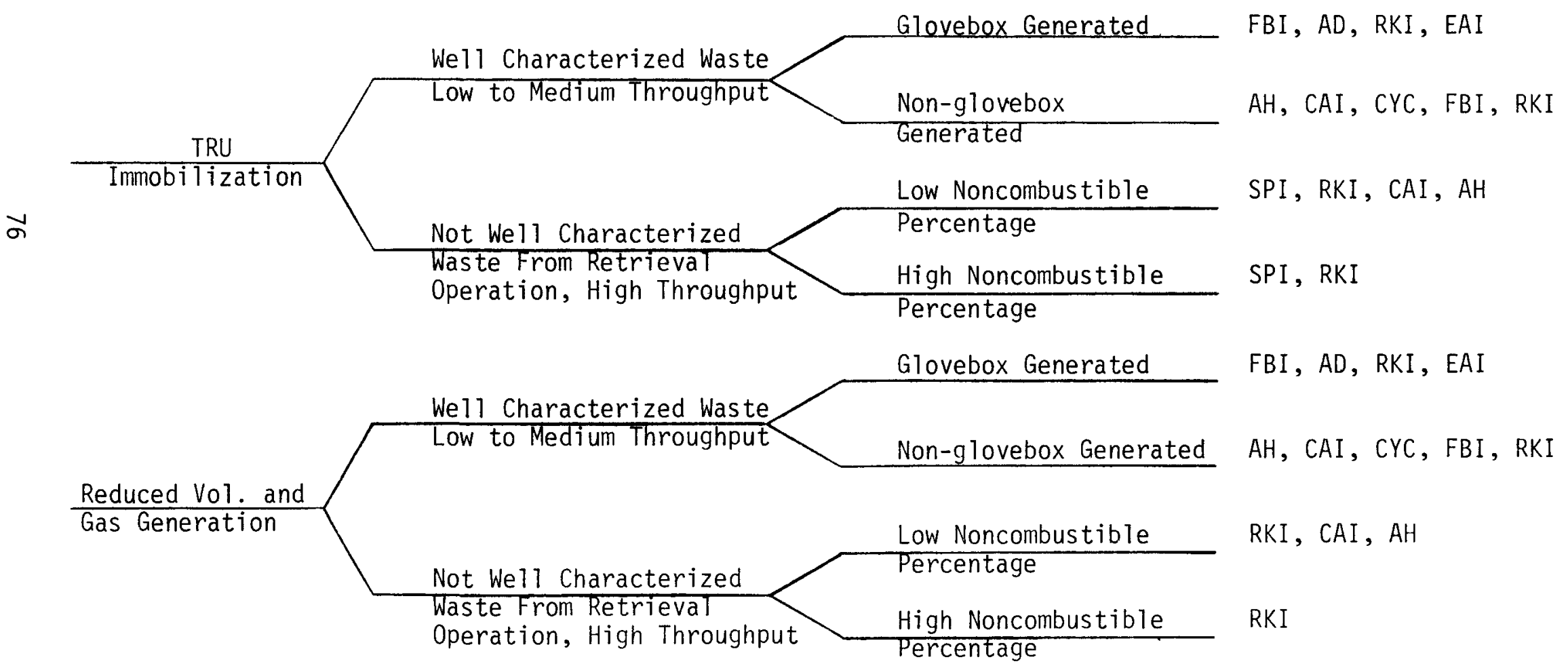

$A D$, Acid Digestion Unit $\mathrm{AH}$, Agitated Hearth Inc. CAI, Controlled Air Inc.
CYC, Cyclone Drum Inc.

EAI, Electric Controlled Air Inc.

FBI, Fluidized Bed Inc.
MS, Molten Salt Inc.

RKI, Rotary Kiln Inc.

SPI, Slagging Pyrolysis Inc. 
FIGURE 4-2

LOW LEVEL WASTE INCINERATION SELECTION MATRIX

OBJECTIVE OF UTILIZING

INC INERAT ION

WASTE AND SITE SPECIFIC FACTORS

APPLICABLE

INC INERATION

SYSTEMS

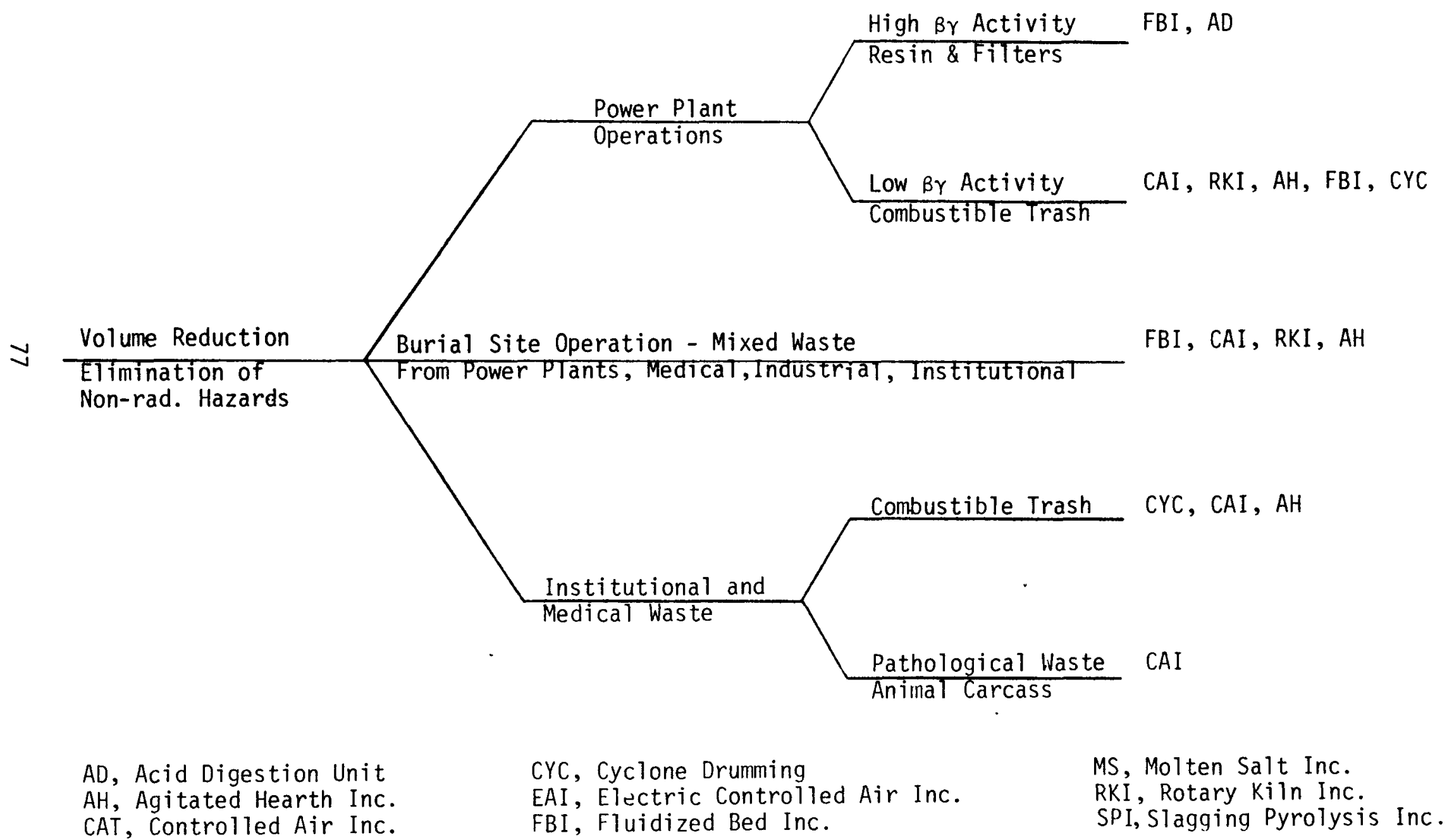




\subsubsection{TRU Waste Applications}

The incinerator waste applications can be broken down into the three categories discussed in the following subtopics.

\subsubsection{Transuranic Recovery}

Combustible materials which are to be processed to recover TRU elements will contain greater concentrations of fissile materials than other TRU combustible waste. The content of fissile materials will necessitate selection of an incinerator which lends itself well to nuclear criticality control. The combustibles will contain higher levels of PVC plastic (up to 50 wt percent). Since it will probably be currently generated material, a high degree of segregation of noncombustible materials should be possible. Because incineration of plutonium contaminated materials at high $\left(800^{\circ} \mathrm{C}\right)$ temperatures produces a refractory type of plutonium oxide which is more difficult to dissolve, a site specific factor has been provided with respect to the type of dissolution system which will be available for processing the ash. If a nitric acid dissolution system is to be used, then the desired incinerator would be a low temperature unit. If the dissolution system to be used can handle high fired oxide, then the major factor affecting the incinerator selection will be nuclear criticality control.

If dissolution enhancement is not available, the acid digestion ( $A D$ ) unit and the fluidized bed incinerator (FBI) are the leading candidates for this application. The acid digestion unit is a low temperature process which produces a soluble sulfate for recovery operations. Because it is a highly moderated and reflected aqueous system, nuclear criticality control has dictated the use of size limitations and geometrical configuration restraints. The unit at HEDL has undergone a complete nuclear safety evaluation and is suitable for handling the high concentration of fissile material encountered in recovery operations. Because it is an aqueous system there is very little carryover of fissile material into the off-gas 
system, minimizing geometrical and size restrictions of that equipment. Because of the equipment size limitations for the head end process, it is best suited for small throughput. The unit is constructed of acid resistant materials and is suitable for the high PVC feed material. The $\mathrm{HCl}$, generated from the decomposition of (the high percentage of) PVC plastic in the feed, would be vented to the atmosphere in the HEDL facility. In addition to the acid fractionating equipment used at $\mathrm{HEDL}$, an $\mathrm{HCl}$ scrubbing system may have to be added to the system to make it acceptable at many other locations. The unit is considered a high capital cost unit per $\mathrm{kg}$ of waste handled, and this cost would be increased with the addition of a $\mathrm{HCl}$ scrubbing system.

The FBI operates at moderate temperatures $\left(550-600^{\circ} \mathrm{C}\right)$ to produce a non-refractory type of plutonican oxide in the ash when processing plutonium contaminated materials. The in situ neutralization of acid gases with the bed material makes the FBI an ideal candidate for processing a high concentration of PVC plastic in the feed stream, thereby minimizing halide corrosion throughout the system. The ash produced is continuously elutriated from the bed by the gas stream. This results in very low inventory of fissile material holdup in the unit. The low inventory of fissile material combined with the totally dry process, minimizing moderation and reflection of neutrons, renders the unit suitable for processing high levels of fissile material. The capital cost per $\mathrm{kg}$ of waste capacity is lower for the FBI than that of the $A D$ unit primarily because of higher throughput capabilities. The plutonium oxide produced by the FBI would be slightly less soluble than the sulfate produced by the $A D$ unit. While both the $A D$ and the FBI are good processes for TRU recovery operations, the $A D$ is better suited for lower capacities, and the FBI may cost less and be better suited for higher throughputs.

The molten salt process would appear to be a possible candidate for this application because of the in situ neutralization of acid gases and the production of soluble forms of TRU elements in the salt cake. However, the large amount of salt compared to the ash (maximum of about $20 \%$ ash) and 
the fact that the unit will maintain a high inventory of fissile material in the salt bath, renders it somewhat less attractive than the $A D$ and $F B I$ processes. With proper administrative control for nuclear safety, it can be considered a marginal candidate.

The Rotary Kiln (RKI), Controlled Air (CAI), Electric Controlled Air (EAI), Slagging Pyrolysis (SPI), Agitated Hearth (AH), and Cyclone Drum (CYC) incinerators are undesirable candidates for this application because of elevated operating temperatures $\left(>800^{\circ} \mathrm{C}\right)$ producing refractory oxides of TRU elements. Some of these candidates are also inadequate because of the potential for accumulation of fissile material in the process equipment under normal operating conditions.

If dissolution enhancement is available, other incinerators are also good choices. For the reasons stated in the previous section, the FBI and $A D$ units are also good candidates for use in TRU recovery operations where dissolution enhancement is available. If enhanced dissolution is available, the recovery efficiency can be improved for the product from either the FBI or $A D$ as compared to a straight nitric acid system.

The availability of an enhanced dissolution makes possible the use of some of the incinerators which operate at high temperatures. One of the primary criteria for an acceptable system in this application is the nuclear criticality control features of the process. The RKI and EAI are good candidate processes for this application.

The RKI has been designed to burn both liquid and solid TRU contaminated materials for recovery at the Rocky Flats Plant. The primary chamber normally operates at $800^{\circ} \mathrm{C}$ with $1000^{\circ} \mathrm{C}$ temperature maintained in the afterburner. The rotation of the kiln provides for continuous automatic removal of ash to minimize the inventory of fissile material in the unit. The ash will be in a well defined small stream the full length of a kiln. At least . two failsafe conditions must be met to introduce liquid in the incinerator; i.e., minimum temperature and flame required to feed liquids and a double 
gravity overflow to prevent scrub liquid backup into the kiln. These features allow the fissile material inventory to exist with minimal moderation and reflection. Of greater concern is the possibility of accumulating fissile material in off-gas cleaning equipment. A combination of geometrical size limitations, boron glass Raschig rings, and gravity overflow are used for criticality control. The system has undergone a complete nuclear safety evaluation and is suitable for handling a high concentration of fissile material on a continual basis. It was also designed to process a feed containing up to 50\% PVC plastic and will accommodate a high level of noncombustibles. The unit at Rocky Flats is designed to process $45 \mathrm{~kg} / \mathrm{hr}$ of high PVC content solid waste and chlorinated solvents, and could be adopted to greater throughputs.

The EAI at SRL was designed for a capacity of about $5 \mathrm{~kg} / \mathrm{hr}$ of solid waste. Because of the low throughput, the unit could be satisfactorily operated with high concentrations of fissile material through administrative control on the feed to the unit. Because no liquid fuel is used in the primary chamber moderating conditions are minimized. Gravity removal of the ash is provided before the gas passes into the afterburner and the off-gas scrubbing system. The unit is well suited for a high concentration of PVC in the feed because the metal equipment exposed to combustion conditions is minimized. However, because of the small throughput, the capital cost per $\mathrm{kg}$ of waste capacity is high.

The EAI and the AD units are best suited to small capacity applications and are both higher cost units. The FBI and the RKI are more suitable to high throughput applications.

The AH, CAI, and SPI are not desirable candidates for combustion of high levels of fissile materials because of high inventory of ash in the equipment under normal operating conditions. The AH is operated batchwise, where the ash is accumulated from 5 hours of operation before . discharge and the ash removal system does not permit for complete removal of the ash from the hearth plate. The CAI does not provide a method for 
complete removal of ash from the hearth plate during normal operations and the total amount of waste inventory in the SPI incinerator would make it somewhat undesirable for high levels of fissile material. The SPI unit also produces a product form that would be unsuitable for processing for TRU element recovery. The high temperatures of operation of the CYC would 1 imit its use for TRU recovery applications. The off-gas scrubbing equipment of each of these systems is not acceptable for treating off-gas from combustion of high levels of fissile material.

\subsubsection{Transuranic Immobilization}

Generally, the TRU combustibles, which are to be processed to produce an immobilized product for transportation and storage, will contain less fissile material than those processed for TRU recovery. This lower fissile material content will reduce the level of restrictions placed on the process for nuclear safety control. Since much of this waste material will be generated outside of glove boxes, it will contain less PVC plastic, which is primarily generated from glove box bagout operations. Since the objective is to convert the TRU combustible material to an immobilized product, either the incinerator should produce an immobilized product or should produce an intermediate product which would be compatible with subsequent processing to produce the immobilized product. The secondary waste produced by the incineration process will also have to be considered as a feed to an immobilization process. The secondary waste will include the salts produced from conversion of aqueous scrub solutions to a dry product.

If the waste is coming from a retrieval operation, it may not be well characterized. However, if the waste is being processed from a current operation, the waste may be well characterized and most of the noncombustibles could be segregated from the combustible materials. Each of these waste and site specific factors are considered separately in selection of . suggested incineration processes. 
The wastes are split into two categories for this discussion, those which are well characterized and those which are not well characterized. Newly generated wastes can usually be segregated and are thus well characterized. The major factor affecting the selection of a suitable incineration system will be the fissile material concentration level in the waste. For the waste generated in glove box operations, nuclear safety considerations discussed in Section 4.2.1.1 would apply to the selection of an incinerator. Therefore, the $A D$ unit, the FBI, the RKI, and the EAI are acceptable for this application. Some of the immobilization processes being developed for subsequent treatment of ash or residue from the combustion unit may not be able to tolerate the high sulfate concentration of the $A D$ residue. This could eliminate the use of $A D$ for specific site applications.

The waste generated outside of the glove box line in the TRU processing areas will contain very low levels of fissile material. Less stringent restrictions can be used to maintain nuclear criticality control in the incineration operations. The four combustion processes identified as acceptable for the glove box generated waste could equally well be utilized for the non-glove box generated waste. In addition, the AH, CAI, and CYC are also considered technically acceptable for this application. However, because of the high capital cost per $\mathrm{kg}$ of waste processing capability in the case of the acid digestion and the EAI processes, they are undesirable candidates for this application. This is particularly true when several less costly processes are available covering a wide capacity range. For the SPI process to be suitable for this category of waste, it will have to be demonstrated at a much lower capacity than the present commercial systems. The cost of this unit is also very high per $\mathrm{kg}$ of processing capacity.

A slightly different set of conditions apply when the wastes are not well characterized and segregated. Major exhumation operations will .produce a feed stream which is not well characterized and may contain a 
significant quantity of soil as well partially decomposed packaging material and a composite of combustibles and noncombustibles. If the waste comes from an exhumation operation, it may contain a wide variety of TRU elements which may restrict the amount of sorting or treatment performed prior to processing. Because some of the waste may be from early operations of government laboratory and production facilities, each package may contain a wide variety of scrap metal, combustibles sludges, etc. Retrieval of more recently produced waste may result in a better segregation of combustibles from scrap metal and solid residues or sludges.

For the waste containing a low percentage of noncombustible material, the SPI, RKI, CAI, and AH are suitable candidates. However, if higher. concentrations of fissile material are present in the waste, only the RKI process contains adequate nuclear criticality control features. The SPI is a highly desirable candidate if the concentration of the fissile material can be accommodated by the unit. This unit can accept a wide variation of feed composition and produces an immobilized product directly. A very low level of fissile material will be needed before the CAI or AH can be utilized. Because of the need for pretreatment or shredding of feed materials, the AD unit, the FBI process, and the EAI system seem to be less desirable candidates for this application. In addition, the $E A I$ and the $A D$ unit have high capital cost per $\mathrm{kg}$ of throughput capacity.

For the case where the waste would contain high percentages of noncombustible materials, the SPI unit and the RKI would be the only acceptable candidates. The RKI would be the preferred process for higher concentrations of fissile material. For lower concentrations of fissile material, the SPI may be the preferred process because of the direct conversion to an immobilized product form. The CAI and the AH are not well suited for processing waste containing large percentages of scrap metal or other noncombustible materials. Because of waste shredding requirements, the $A D$ unit, FBI, and the EAI are not well suited for this waste application. 


\subsubsection{Reduced Volume and Gas Generation}

The type of TRU combustible wastes which would be processed for volume reduction or elimination of gas generation characteristics can be considered comparable with those wastes processed for TRU immobilization. The waste and site specifications, presented in Figure 4-1, for this incineration objective are the same factors used for the TRU immobilization case. The logic used for selecting incinerator candidates is similar, except that because of the volume reduction objective, the SPI process would not appear to be a logical candidate. The product volume from this unit is larger than from other systems because of materials added to produce a slag. The candidate combustion processes suggested for this application are presented in Figure $4-1$.

\subsubsection{LLW Applications}

In addition to reducing the volume of the low level waste, which could reduce transportation costs and conserve space at disposal sites, incineration of combustibles can improve the safety of transportation and disposal operations. Incineration will reduce the fire hazards of the waste and will produce an ash which is chemically inert. However, regulations may require some form of immobilization before shipment or storage. Three major waste and site specific factors, which will help in defining the type of combustion process that would be best suited for processing the low level waste, are presented in Figure 4-2.

\subsubsection{LLW from Power Plant Operations}

The major portion of the combustible LLW generated at power plants also has only low levels of $\beta-\gamma$ activity. This waste generally will contain a high percentage of plastic and paper and lower percentages of cloth, rubber, glass, and wood. It can contain up to about $20 \%$ PVC . plastic. The plants will also generate some waste oils, ion exchange resin, and sludges collected on filter elements. The ion exchange resin and sludge filters will tend to be of higher $\beta-\gamma$ activity. 
Most of the combustion processes considered in this report have been developed for use with TRU waste. They have not been tested with $\beta-\gamma$ waste, and some development or testing will have to be done before they could be applied to $\beta-\gamma$ waste. Most off-gas systems would have to be modified to remove volatile isotopes. Testing with spiked waste would then be required to evaluate the off-gas cleaning systems. Some development would be needed to evaluate the combustion processes for burning the types of ion exchange resin and oils in power plant waste. An experimental program is now under way to evaluate the controlled air incinerator for these types of materials, as well as removal of fission products from the off-gas.

Two processes, the FBI and the AD unit, have processed the types of ion exchange resins used in TRU operations. When resin is transported as a slurry and the water drained off, the resin beads will contain about 50 wt percent water. Experience has shown that resin beads containing 50 wt percent water will fracture when atomized in a high temperature process, resulting in premature carryover of unburned resin into the off-gas system. Also, resin burned in bulk on a hearth plate or pan tend to carbonize, preventing complete combustion unless continual mixing is provided. The addition of the resin beads under the aqueous surface in $A D$ or under the surface of the bed in the FBI has resulted in good combustion of the resin. These two units are the best candidates for the high $\beta-\gamma$ activity waste (resin and sludge filters) at the present time. Both systems would need testing for removal of the volatile isotopes. In the FBI process, iodine could be removed by reaction with the sodium carbonate bed material in the primary vessel. However, this would also have to be demonstrated. Both of these units could be designed and operated to minimize operator radiation exposure.

For the low $\beta-\gamma$ activity waste (combustible trash and oils) the CYC, RKI, $A H$, and FBI are the preferred candidates. The $A D$ unit has exhibited . some problems in combusting normal parafin hydrocarbons and may have problems with the waste oils. The capacity of slagging pyrolysis exceeds 
that which would normally be required for power plant waste generation. The EAI and the SPI would be quite high in capital cost for this application.

\subsubsection{Burial Site LLW}

If the waste being received at a LLW disposal site is to be incinerated, one can expect a wide variety in feed composition and $\beta-\gamma$ activity levels. The capacity requirements of an incinerator would be considerably higher than that for a power plant or single industrial application. The high $\beta-\gamma$ activity waste may be segregated from the other waste because of shielding requirements during transportation. As discussed previously, the resin and high $\beta-\gamma$ activity filters could be handled by a FBI or the $A D$ process. However, if pathological waste such as animal carcasses are to be processed, a second incineration system may be necessary, such as the CAI, RKI, or AH incinerator. Because of the high cost and low capacity of the $A D$ process and the EAI, these processes are not well suited for this application. The CYC process does not seem well suited for processing ion exchange resins or animal carcasses. It would appear suitable for processing only the drums of combustible trash, and because of its 1 inited applicability to other waste, is not considered an acceptable candidate for burial site operations. Both the Molten Salt and the SPI units appear to add considerably to the quantity of waste product and are not well suited for processing at a burial site.

\subsubsection{Institutional and Medical Wastes}

Because combustible trash from institutional and medical facilities would be similar to the combustible trash from power plant operations, the same logic can be used to select suitable combustion processes. However, the volume of waste to be processed should be quite low and the incinerator for this application should either be a low capacity unit or a batch opera- tion which could be started up and shut down easily. The CYC incinerator is the preferred candidate with the AH and the CAI being acceptable units. For the pathological wastes, the CAI would be the best process, utilizing supplemental firing and a long residence time to complete combustion. 


\subsection{CONCLUSIONS}

1. Incineration of combustible radwaste can significantly reduce the volume of waste requiring immobilization and/or disposal. Incineration will el iminate the fire hazard and reduce the chemical reactivity of the waste subjected to subsequent processing, transportation, and disposal operations.

2. All of the incineration systems developed recently in the U.S. have been thoroughly tested and demonstrated suitable for processing the general trash, such as plastic, paper cloth, etc., which is common to TRU waste. However, many of these systems have not been demonstrated suitable for processing some specific waste components such as TBP-solvent mixture, ion exchange resin, or lead loaded gloves.

3. Each of the recently developed TRU waste incineration systems have been identified as a preferred candidate for one or more specific applications, as shown in Figure 4-1 and 4-2. The available systems represent capacities ranging 5 to $850 \mathrm{~kg} / \mathrm{hr}$.

4. The Fluidized Bed Incinerator, Rotary Kiln Incinerator, Electric Controlled Air Incinerator, and the Acid Digestion Unit were designed to accommodate high levels, as well as low levels, of fissile material. The Agitated Hearth, Controlled Air, and Cyclone Drum incinerators were designed for processing combustible waste with low concentrations of fissile material and extensive equipment modification would be required to implement the needed nuclear criticality control for these units to be suitable for processing high levels of fissile material.

5. A considerable benefit could be realized in terms of waste volume reduction and improved safety of low level waste operations if incineration is utilized. Many of the combustion systems developed 
for processing TRU waste appear to be applicable to treatment of low level waste, however, they have not been tested with LLW, and the offgas systems would have to be modified to accommodate removal of volatile fission products.

6. None of the recently developed TRU waste incineration have been demonstrated for total remote operation and maintenance.

7. The present burial ground capacities for low level commercial waste are adequate for present generation rate. However, reduction in amounts being accepted at specific sites and political disruptions of receiving waste at other sites has created a present need for incineration of commercial low level combustibles for volume reduction. The projected commercial LLW generation will exceed the burial capacities in 20 years unless additional capacity is developed. The present storage capacities for LLW and TRU waste at DOE facilities exceed the present waste volume and projected generation of DOE waste for the next 20 years. However, the projected volumes will exceed the storage capabilities at ORNL and LANL necessitating either shipment of waste to alternate sites or the use of incineration for volume reduction. 


\subsection{RECOMMENDATIONS}

1. Research and development of TRU incineration should be pursued only in support of well defined specific applications. Generic background data is available on the incineration systems for present contact handled TRU waste.

2. The TRU waste incineration technology should be transferred to the commercial nuclear industry for processing low level waste. This will require experimental testing to demonstrate combustion of component waste materials, and removal of fission products from the incinerator off-gas. A technology transfer program for the Controlled Air Incinerator is providing technical advise and experimental information for commercialization of that system. If other systems are selected for low level waste application, they should be subjected to the same type of testing and evaluations.

3. Nuclear safety documentation should be provided for all incineration systems specifically designed for processing waste with high levels of fissile processing material. The Acid Digestion Unit, Slagging Pyrolysis, Electric Controlled Air, and Rotary Kiln Incinerator syteins will be, or are being, inplemented in production operations and the nuclear safety data should become available as a part of the implementation activities. The Fluidized Bed Incinerator was designed to process waste containing up to 0.8 percent ${ }^{239} \mathrm{Pu}$. Since the unit has not processed glove box generated waste, nuclear safety experiments should be conducted and the process demonstrated with actual glove box generated waste as a part of the nuclear safety documentation. For incinerators which were not constructed with TRU waste management funds, such as the Rotary Kiln, the documentation of nuclear safety and operating information is more important because the present published information is somewhat limited. 
4. Remote operation and maintenance of an incineration system will be needed if low level waste with high levels of $\beta-\gamma$ activity are to be processed. The used ion exchange resin and cartridge filter from nuclear power plant operations represent the types of high $\beta-\gamma$ waste materials. The Acid Digestion Unit and the Fluidized Bed Incinerator are the preferred candidates for this type of waste because of their demonstrated ability to process ion exchange resin, and they do not utilize refractories which can become impregnated with $\beta-\gamma$ type materials. If the presently planned combustion tests of resin and oil in the CAI (as a part of the commercialization of that system) are successfur, this unit will also become a logical candidate for remote process development work. Design and experimental work will be required to demonstrate remote operation and maintenance of any of the TRU combustion systems if the TRU waste technology is to be applied to high $\beta-\gamma$ waste. 


\subsection{REFERENCES}

1. "Spent Fuel and Waste Inventories and Projections," OR0-778, U.S. Department of Energy, Oak Ridge Operations office, Oak Ridge, TN (August 1980).

2. E. S. Goldberg, C. R. Allen, J. A. Bowman, H. E. Hootman, D. F. Luthu, A. S. Neuls, and D. L. Ziegler, "Transuranic Waste Technology Assessment Task Group Reports" (December 1977).

3. C. R. Cooley and D. E. Clark, "Treatment Technologies for Non-HighLevel Wastes (U.S.A.)," International Symposium on the Management of Wastes from the LWR Fuel Cycle, Denver. (July 1976).

4. Betty L. Perkins, "Incineration Facilities for Treatment of Radioactive Wastes: A Review," Los Alamos Scientific Laboratory Report, LA6252 (July 1976).

5. C. Allen, R. Cowan and J. Divine, "Acid Digestion of Combustibles Waste - Status Report 2," Hanford Engineering Development Laboratory report TME 78-77 (October 1978).

6. C. R. Allen and P. C. Ely, "Acid Digestion of Combustible Waste Status Report 3," Hanford Engineering Development Laboratory report TME 79-64 (August 1980).

7. R. E. Lerch, C. R. Al len, and G. L. Richardson, Division of Waste Management Programs Progress Report, Hanford Engineering Development Laboratory report TME 79-15 (July 1979).

8. Donald L. Ziegler, "Incineration Process Fire and Explosion Protection," presented at the 13th AEC Air Cleaning Conference, San Francisco, CA (March 1975).

9. L. J. Johnson, ed., "Nuclear Waste Technology Development Activities, January-December 1978," Los Alamos Scientific Laboratory report LA-7921-PR (June 1979).

10. Leon C. Bordiun and Anibal L. Taboas, "USDOE Radioactive Waste Incineration Technology: Status Review," presented at Waste Management 1980, Tucson, AZ, LA-UR-80-692 (March 1980).

11. H. S. Jordan et al., "Conceptual Design Report for the Transuranic Contaminated Solid Waste Treatment Development Facility TA-50," Los Alamos Scientific Laboratory Engineering Department report ENG-9-RP-54 (September 1973).

12. Leon C. Borduin, "US High Temperature Incineration R\&D for Treatment of Alpha-Bearing Wastes," presented at NEA/OECD Workshop on High Temperature Incineration of Alpha-Bearing Wastes. Mol, Belgium, LA-UR-79-2972 (March 1980). 
13. L. M. Klingler, "Defense Waste Cyclone Incinerator Demonstration Program: April-September 1979," Mound Facility report MLM-2672 (December 1979).

14. Larry M. Klingler, "Defense Waste Cyclone Incinerator Demonstration Program: October 1979-March 1980," Mound Facility report MLM-2716 (June 1980).

15. J. H. Warren, "Design of an Experimental Incinerator for Alpha Waste," Savanna River Laboratory report DP-1521 (August 1979).

16. Donald L. Ziegler, "Fluidized Bed Incineration of Radioactive Waste," Rocky Flats Plant report RFP-2741 (May 1976).

17. Andrew J. Johnson, et al., "Fluidized Bed Incineration Process Design for Transuranic Waste," Rocky Flats Plant report RFP-2945 (July 1980).

18. D. E. McKenzie, et a1., "Disposal of Transuranic Solid Waste Using Atomics International Molten Salt Combustion Process," Rockwell International report AI-ERDA-13151 (May 1975).

19. L. F. Grantham, et al., "Disposal of Transuranic Solid Waste Using Atomics International's Molten Salt Combustion Process II," Rockwell International report AI-ERDA-13169 (March 1976).

20. Final Report, "Selection of Waste Treatment Process for Retrieved TRU Waste at Idaho National Engineering Laboratory," FMC Corporation document R-3689 (November 1977).

21. A. H. Kibbey and H. W. Godbee, "A State-of-the-Art Report on Low-Level Radioactive Waste Treatment," Oak Ridge National Laboratory report TM-7427 (September 1980). 
8.0 APPENDICES 
APPENDIX $A$

Appendix $\underline{A}$

Page I

EARLY UNITED STATES RADIOACTIVE WASTE INCINERATORS

\begin{tabular}{|c|c|c|c|c|c|c|c|}
\hline & LOCATION & $\begin{array}{l}\text { PERIOD OF } \\
\text { OPERATION }\end{array}$ & INC INERATOR TYPE & OFF GAS SYSTEM & $\begin{array}{l}\text { CAPAC ITY } \\
(\mathrm{kg} / \mathrm{hr})\end{array}$ & $\begin{array}{l}\text { COMBUSTIBLE } \\
\text { WASTES NOT } \\
\text { ACCEPTABLE }\end{array}$ & COMMENTS \\
\hline \multirow[t]{2}{*}{ I. } & $\begin{array}{l}\text { Mound Laboratory } \\
\text { Miami sburg, } \mathrm{OH}\end{array}$ & $1948-1950$ & Pilot Unit - other unknown & $\begin{array}{l}\text { Steam injector, water } \\
\text { cooled expansion chamber, } \\
\text { spray/packed tower }\end{array}$ & Unknown & Unknown & $\begin{array}{l}\text { Limited use, retain- } \\
\text { ed } 98.8 \% \text { radio- } \\
\text { octivity }\end{array}$ \\
\hline & & $1950 ?$ & $\begin{array}{l}\text { Pilot Unit - Electrically heated; } \\
\text { tangential air nozzels into } \\
\text { stainless steel vertical tube } \\
\text { with bottom grate }\end{array}$ & $\begin{array}{l}\text { Coarse filter, water spray, } \\
\text { heat exchanger, scrubber, } \\
\text { heat exchanger, steam nozzle, } \\
\text { expansion chamber, heat ex- } \\
\text { changer, scrubber, filter }\end{array}$ & 6.8 & Unknown & $\begin{array}{l}\text { Appears only } 5 \text { cold } \\
\varepsilon 7 \text { hot runs made, } \\
\text { burning } 9.1 \mathrm{~kg} \\
\text { waste generated } \\
1260 \text { gal. of con- } \\
\text { taminated water }\end{array}$ \\
\hline \multirow[t]{2}{*}{11.} & $\begin{array}{l}\text { Knolls Atomic Power } \\
\text { Laboratory, } \\
\text { Schenectady, NY }\end{array}$ & $1949-1950$ & $\begin{array}{l}\text { Pilot Unit; unknown other than } \\
\text { pure oxygen used and bottom } \\
\text { grate for ash dropout }\end{array}$ & $\begin{array}{l}\text { Condensation column, sulfur } \\
\text { burner to remove oxygen, } \\
\text { agglomeration section, } \mathrm{CO}_{2} \\
\text { packed absorption tower, } \\
\text { centrlfugal waster, re- } \\
\text { heater, CWS filter }\end{array}$ & 9.1 & Unknown & $\begin{array}{l}\text { Tried to "dead end" } \\
\text { of fgas, performed } \\
\text { very poorly, system } \\
\text { redesigned in } 1950\end{array}$ \\
\hline & & $1950-1951$ & $\begin{array}{l}\text { Retained from } 49-50 \text { pilot unit; } \\
\text { added firebrick wall and pro- } \\
\text { pane gas burner }\end{array}$ & $\begin{array}{l}\text { Settling chamber, scrubber, } \\
\text { condensor, reheater, coarse } \\
\text { filter, CWs filter }\end{array}$ & 18.2 & Unknown & $\begin{array}{l}\text { Problems with fil- } \\
\text { ters and scrubber } \\
\text { lines plugglng, } \\
\text { some corrosion }\end{array}$ \\
\hline 111. & $\begin{array}{l}\text { Argonne National } \\
\text { Laboratory } \\
\text { Argonne, ILL }\end{array}$ & $1951-1955$ & $\begin{array}{l}\text { All welded stainless steel verti- } \\
\text { cal cylinder with movable grates; } \\
\text { primary air nozzles below grates; } \\
\text { secondary air and gas burners } \\
\text { above grate }\end{array}$ & $\begin{array}{l}\text { Ten plate centrifugal gas } \\
\text { washer, venturi scrubber, } \\
\text { Peabody scrubber, reheater, } \\
\text { AEC filters }\end{array}$ & $68(\max )$ & $>50 \mathrm{mR} / \mathrm{hr}$ & $\begin{array}{l}\text { Some corrosion and } \\
\text { plugging problems, } \\
\text { cost-benefit analys is } \\
\text { showed unit economic } \\
\text { only with } 74 \text { hr op- } \\
\text { eration so shut down }\end{array}$ \\
\hline IV. & $\begin{array}{l}\text { Los Alamos Scientific } \\
\text { Laboratory } \\
\text { Los Alamos, NM }\end{array}$ & $1951-1953$ & $\begin{array}{l}\text { Production unit with batch charg- } \\
\text { ing; cylindrical combustion cham- } \\
\text { ber with tangential underfire alr } \\
\text { below grate and overflre alr } \\
\text { above grate; auxillary gas bur- } \\
\text { ners }\end{array}$ & $\begin{array}{l}\text { Dry cyclone, spray cooler, } \\
\text { venturi scrubber, two- } \\
\text { stage fiberglass filter }\end{array}$ & $45-91$ & $\begin{array}{l}\text { Essentially } \\
\text { None }\end{array}$ & $\begin{array}{l}\text { Waste not presorted, } \\
\text { burned in cardboard } \\
\text { shipping box, poor } \\
\text { combustion and over- } \\
\text { pressure large prob- } \\
\text { lems, noncombust ibles } \\
\text { clogged grate }\end{array}$ \\
\hline
\end{tabular}




\begin{tabular}{|c|c|c|c|c|c|c|c|}
\hline & LOCATION & $\begin{array}{l}\text { PERIOD OF } \\
\text { OPERATION }\end{array}$ & INCINERATOR TYPE & OFF GAS SYSTEM & $\begin{array}{l}\text { CAPACITY } \\
(\mathrm{kg} / \mathrm{hr})\end{array}$ & $\begin{array}{l}\text { COMBUSTIBLE } \\
\text { WASTES NOT } \\
\text { ACCEPTABLE } \\
\end{array}$ & COMMENTS \\
\hline v. & $\begin{array}{l}\text { Bett is Atomic } \\
\text { Power Laboratory } \\
\text { West Mifflin, PA }\end{array}$ & $1953-1969$ & $\begin{array}{l}\text { Cylindrical firebrick lined com- } \\
\text { bustion chamber of steel, tan- } \\
\text { gential air nozzles; bottom } \\
\text { grate }\end{array}$ & $\begin{array}{l}\text { Fog spray nozzle, roto- } \\
\text { clone, damper }\end{array}$ & Unknown & $>40 \mathrm{mR} / \mathrm{hr}$ & $\begin{array}{l}\text { Consisted of two } \\
\text { nearly identical } \\
\text { units, I started } \\
1953 \text {, other in } 59 \text {, } \\
\text { shut down due to } \\
\text { higli maintenance } \\
\text { costs }\end{array}$ \\
\hline vi. & $\begin{array}{l}\text { Shippingport Atomic } \\
\text { Power Station, PA }\end{array}$ & Unknown & Unknown & Unknown & Unknown & Unknown & $\begin{array}{l}\text { Problems with in- } \\
\text { complete conbus- } \\
\text { tion due to low } \\
\text { temperatures }\end{array}$ \\
\hline \multirow[t]{2}{*}{ vit. } & $\begin{array}{l}\text { United Nuclear In- } \\
\text { dustrles } \\
\text { Richland, WA }\end{array}$ & $1949-1960$ 's & Open pit or trench & None & Unknown & Unknown & $\begin{array}{l}\text { Discontinued after } \\
\text { empty oil dium ex- } \\
\text { plosions }\end{array}$ \\
\hline & & $1967-1971$ & $\begin{array}{l}\text { Natural draft incinerator } \\
\text { over an ash pit }\end{array}$ & None & Unknown & Unknown & $\begin{array}{l}\text { Were two units, one } \\
\text { started in } 1967 \text {, } \\
\text { other in } 1968 \text {, } \\
\text { wastes now buried } \\
\text { directly }\end{array}$ \\
\hline \multirow[t]{2}{*}{ vili. } & $\begin{array}{l}\text { Bureau of Mines, Com- } \\
\text { bust ion Research } \\
\text { Pittsburgh, PA }\end{array}$ & $1954-1955$ & $\begin{array}{l}\text { Pilot Unit - Cylindrical steel } \\
\text { combustion chamber feed tan- } \\
\text { gential overfire air; cyclone } \\
\text { type; called BOMAEC- } 30\end{array}$ & $\begin{array}{l}\text { Heat exchanger, glass- } \\
\text { fiber bag filters, AEC } \\
\text { type filter }\end{array}$ & Unknown & $\begin{array}{l}\text { Contami- } \\
\text { nated } \\
\text { wastes, } \\
\text { cold tested } \\
\text { only }\end{array}$ & $\begin{array}{l}\text { Tried only on saw- } \\
\text { dust, tested by } \\
\text { Harvard Air Clean- } \\
\text { ing Lab., ACL, and } \\
\text { judged unsat isfact- } \\
\text { ory }\end{array}$ \\
\hline & & 1955 & $\begin{array}{l}\text { First modification of BOMAEC- } 30 \\
\text { with deeper combustion chamber }\end{array}$ & Spray cooler added to above & Unknown & $\begin{array}{l}\text { Contamina- } \\
\text { ted wastes, } \\
\text { cold tested } \\
\text { only }\end{array}$ & $\begin{array}{l}\text { Tried on sawdust } \\
\text { mixed with rubbish, } \\
\text { ACL tests showed } \\
\text { still unsatisfac- } \\
\text { tory }\end{array}$ \\
\hline
\end{tabular}


EARLY UNITED STATES RADIOACTIVE WASTE INCINERATORS

\begin{tabular}{|c|c|c|c|c|c|c|c|c|}
\hline & LOCATION & $\begin{array}{l}\text { PERIOD OF } \\
\text { OPERATION }\end{array}$ & INCINERATOR TYPE & OFF GAS SYSTEM & & $\begin{array}{l}\text { CAPACITY } \\
(\mathrm{kg} / \mathrm{hr})\end{array}$ & $\begin{array}{l}\text { COMBUSTIBLE } \\
\text { WASTES NOT } \\
\text { ACCEPTABLE }\end{array}$ & COMMENTS \\
\hline & & $\begin{array}{l}1955 \\
\text { (approx) }\end{array}$ & $\begin{array}{l}\text { Second modification of BOMAEC }-30 \\
\text { with auxillary air nozzle at top } \\
\text { and gas burner }\end{array}$ & $\begin{array}{l}\text { Spray cooler added to } \\
\text { above }\end{array}$ & & Unknown & $\begin{array}{l}\text { Contamina- } \\
\text { ted wastes, } \\
\text { cold tested } \\
\text { only }\end{array}$ & $\begin{array}{l}\text { ACL tests showed } \\
\text { low temps and } \\
\text { rapid bag filter } \\
\text { plugging }\end{array}$ \\
\hline & & $\begin{array}{l}1955 \\
\text { (approx) }\end{array}$ & $\begin{array}{l}\text { Final design of BOMAEC }-30 \text { with } \\
\text { top waste feed, otherwise } \\
\text { similar }\end{array}$ & Same as above & & Unknown & $\begin{array}{l}\text { Unknown, } \\
\text { never } \\
\text { operated }\end{array}$ & $\begin{array}{l}\text { ACL analysis in- } \\
\text { dicated unit was } \\
\text { not workable }\end{array}$ \\
\hline & & $\begin{array}{l}1955 \\
\text { (approx) }\end{array}$ & $\begin{array}{l}\text { Called BOMAEC }-100 \text {, a larger } \\
\text { version of BOMAEC }-30\end{array}$ & Same as above & & Unknown & Unknown & $\begin{array}{l}\text { ACL tests gave } \\
\text { similar results } \\
\text { to BOMAEC- } 30\end{array}$ \\
\hline \multirow[t]{2}{*}{ IX. } & $\begin{array}{l}\text { Harvard Air Cleaning } \\
\text { Laboratory } \\
\text { Boston, MASS }\end{array}$ & $\begin{array}{l}\text { late } \\
\text { 1950's }\end{array}$ & $\begin{array}{l}\text { Pilot Unit - } 55 \text { gal. drum lined } \\
\text { with firebrick; tangential over- } \\
\text { fire air; had grate; ash clean- } \\
\text { out port; upper drying chamber }\end{array}$ & Unknown & & Unknown & $\begin{array}{l}\text { Contamina- } \\
\text { ted wastes } \\
\text { cold tests } \\
\text { only }\end{array}$ & $\begin{array}{l}\text { Burned sawdust } \\
\text { only, sometimes } \\
\text { charges exting- } \\
\text { uished flames or } \\
\text { started burning in } \\
\text { drying chamber }\end{array}$ \\
\hline & & $\begin{array}{l}\text { late } \\
\text { 1950's }\end{array}$ & $\begin{array}{l}\text { Modification of above pilot unit; } \\
\text { with side charging door; brick } \\
\text { lined afterburner with auxillary } \\
\text { alr inlet; slidling fork above } \\
\text { grate for drying charges }\end{array}$ & $\begin{array}{l}\text { Air dilution, crushed } \\
\text { and slag-wool filter }\end{array}$ & stone & Unknown & See above & $\begin{array}{l}\text { Flber filters and } \\
\text { electrostatic pre- } \\
\text { clpltators were } \\
\text { both tried and } \\
\text { worked poorly, } \\
\text { specifications } \\
\text { were published }\end{array}$ \\
\hline
\end{tabular}




\begin{tabular}{|c|c|c|c|c|c|c|c|}
\hline & LOCATION & $\begin{array}{l}\text { PERIOD OF } \\
\text { OPERATION }\end{array}$ & INCINERATOR TYPE & OFF GAS SYSTEM & $\begin{array}{l}\text { CAPACITY } \\
(\mathrm{kg} / \mathrm{hr})\end{array}$ & $\begin{array}{l}\text { COMBUSTIBLE } \\
\text { WASTES NOT } \\
\text { ACCEPTABLE } \\
\end{array}$ & COMMENTS \\
\hline$x$. & $\begin{array}{l}\text { U.S. Army Nuclear De- } \\
\text { fense Laboratory } \\
\text { Edgewood Arsenal, MD }\end{array}$ & $1963-7$ & $\begin{array}{l}\text { Production Unit - Primary com- } \\
\text { bustlon chamber with tangential } \\
\text { overfire air; secondary chamber } \\
\text { with tangential auxillary air; } \\
\text { both refractory lined }\end{array}$ & $\begin{array}{l}\text { Air dilution, cyclone, } \\
\text { electrostatic preciptator, } \\
\text { high efficiency filter } \\
\text { bank }\end{array}$ & 22.7 & $\begin{array}{l}\text { High } \\
\text { level } \\
\text { wastes }\end{array}$ & $\begin{array}{l}\text { Stront ium became } \\
\text { fixed in refrac- } \\
\text { tory, much warpage, } \\
\text { funding problems \& } \\
\text { licensing require- } \\
\text { ments shut unit } \\
\text { down }\end{array}$ \\
\hline \multirow[t]{4}{*}{$x i$. } & $\begin{array}{l}\text { Uranium Waste Incinera- } \\
\text { tors: }\end{array}$ & & & & & & \\
\hline & $\begin{array}{l}\text { A. United Nuclear Corp. } \\
\text { Mantville, CT }\end{array}$ & $\begin{array}{l}\text { Early } \\
1960^{\prime} s\end{array}$ & Production, otherwise unknown & $\begin{array}{l}\text { Auxillary fly-ash settling, } \\
\text { stack }\end{array}$ & 95.3 & $\begin{array}{l}\text { High } \\
\text { level } \\
\text { wastes }\end{array}$ & 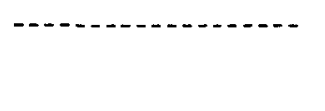 \\
\hline & $\begin{array}{l}\text { B. Metals E Controls } \\
\text { Attleboro, MA }\end{array}$ & $\begin{array}{l}\text { Early } \\
1960^{\prime} s\end{array}$ & Production, otherwise unknown & Cyclone, low stack & 90 & Unknown & $\begin{array}{l}\text { All contaminated } \\
\text { combustibles burned }\end{array}$ \\
\hline & $\begin{array}{l}\text { C. Pratt \& Whitney } \\
\text { Middletown, CT }\end{array}$ & $\begin{array}{l}\text { Early } \\
\text { 1960's }\end{array}$ & Production, otherwise unknown & Exhaust stack & 272 & $\begin{array}{l}\text { High } \\
\text { level } \\
\text { wastes }\end{array}$ & $\begin{array}{l}\text { HLW burned in } 55 \\
\text { gal. drum which } \\
\text { vented to same } \\
\text { stack }\end{array}$ \\
\hline $\mathbf{x} \boldsymbol{x}$. & $\begin{array}{l}\text { G.E. Atomic Power Dept. } \\
\text { San Jose, CA }\end{array}$ & $1960-1962$ & $\begin{array}{l}\text { Production Unit - Three chambers, } \\
\text { firebrick IIned with gas burners } \\
\text { to maintain } 800^{\circ} \mathrm{C} \text { temperature; } \\
\text { removable ash tray }\end{array}$ & $\begin{array}{l}\text { Baffled water-spray cooler } \\
\text { to } 315^{\circ} \mathrm{C} \text {, prefilter, abso- } \\
\text { lute filter }\end{array}$ & 45.5 & $\begin{array}{l}\text { Plastics, } \\
\text { rubber. } \\
\text { tape }\end{array}$ & $\begin{array}{l}\text { Used to burn uranium } \\
\text { contaminated paper } \\
\text { and polyethylene, } \\
\text { unit couldn't meet } \\
\text { load so shut-down, } \\
\text { filter problems from } \\
\text { condensation }\end{array}$ \\
\hline XIII. & $\begin{array}{l}\text { Nuclear Materials and } \\
\text { Equipment Corporation } \\
\text { Apollo, PA. }\end{array}$ & 1969-1971 & $\begin{array}{l}\text { Full scale prototype; single re- } \\
\text { fractory lined chamber with baf- } \\
\text { fles three gas burners to ef- } \\
\text { fect three chamber combustion }\end{array}$ & $\begin{array}{l}\text { Hot unit to have: cyclone, } \\
\text { absolute filters, wet } \\
\text { scrubber, heater. flina! } \\
\text { absolute fllters: proto- } \\
\text { type had stack only }\end{array}$ & 9.1 & $\begin{array}{l}\text { Contami- } \\
\text { nated } \\
\text { waste, cold } \\
\text { waste only }\end{array}$ & $\begin{array}{l}\text { Hot unit never built } \\
\text { due to econonics, } \\
\text { burnling of poly- } \\
\text { ethylene produced } \\
\text { heavy black smoke }\end{array}$ \\
\hline
\end{tabular}

Uranium Waste Incinera-

tors:

$$
\text { Corp. Early }
$$

Metals c Controls

Actleboro, MA

Early

$1960-1962$

Production Unit - Three chambers firebrick lined with gas burners to maintain $800^{\circ} \mathrm{C}$ temperature
Full scale prototype; single ree fles three gas burners to flactory lined chamber with baf-

\author{
Baffled water-spray cooler \\ to $315^{\circ} \mathrm{C}$, p \\ Hot unit to have: cyclone \\ bsolute filters, wet \\ crubber, heat or. flinal \\ type had stack only \\ Auxillary fly-ash settling.
}

20

overfire air: secondary chamber with ire air; secondary chamber electrostatic precipta 22.7

WASTES NOT ACCEPTABLE Stront ium became fixed in refracfunding problems \& licensing require ments shut unit down HLW burned in 55 al. drum which vented to same

Plastics, Used to burn uranium rubber. unit couldn't meet load so shut-down, filter proble it never bu nated due to econonics. waste only ethylene produced heavy black smoke 
RECENT UNITED STATES RADIOACTIVE WASTE INCINERATORS

\begin{tabular}{|c|c|c|c|c|c|c|c|}
\hline & LOCATION & $\begin{array}{l}\text { PERIOD OF } \\
\text { OPERATION }\end{array}$ & INC INERATOR TYPE & OFF GAS SYSTEM & $\begin{array}{l}\text { CAPAC ITY } \\
(\mathrm{kg} / \mathrm{hr})\end{array}$ & $\begin{array}{l}\text { COMBUSTIBLE } \\
\text { WASTES NOT } \\
\text { ACCEPTABLE }\end{array}$ & COMMENTS \\
\hline \multirow[t]{3}{*}{1.} & $\begin{array}{l}\text { National Lead Company } \\
\text { of Ohio } \\
\text { Fernald, OH }\end{array}$ & $1954-?$ & $\begin{array}{l}\text { Production - Refractory lined; } 3 \\
\text { chamber unit; first chamber is } \\
\text { primary burn for oil and second- } \\
\text { ary for trash, afterburner has } \\
\text { gas burners }\end{array}$ & $\begin{array}{l}\text { None, direct exhaust from } \\
\text { afterburner to stack }\end{array}$ & 998 & Plastics & $\begin{array}{l}\text { Low enrichment ur- } \\
\text { anium contaminated } \\
\text { trash and oil sludge } \\
\text { are burned, no major } \\
\text { problems }\end{array}$ \\
\hline & & $1962-?$ & $\begin{array}{l}\text { Production Unit - of tall, refract- } \\
\text { ory Iined cylinder with bottom air } \\
\text { lance and ash rakeout ports }\end{array}$ & $\begin{array}{l}\text { None, stack integral with } \\
\text { incinerator, uranium re- } \\
\text { lease of } .23 \mathrm{~kg} / 24 \mathrm{hr} \text { esti- } \\
\text { mated }\end{array}$ & $\sim 72$ & $\begin{array}{l}\text { Any waste } \\
\text { other than } \\
\text { graphite }\end{array}$ & $\begin{array}{l}\text { Graphite is sized to } \\
2,12 \mathrm{~cm} \text { dia. pieces. } \\
\text { operation is only } \\
4 \text { whs/yr, ash is } \\
260 \% \text { uranium }\end{array}$ \\
\hline & & $1957-?$ & $\begin{array}{l}\text { Production Unit - of burner pot in } \\
\text { bottom of tall stack; compressed } \\
\text { and blower air fed at bottom; six } \\
\text { tank system for removing sludge- } \\
\text { water-volatiles and heating makes } \\
\text { up pretreatment system }\end{array}$ & $\begin{array}{l}\text { None, stack integral with } \\
\text { incinerator }\end{array}$ & 45 & $\begin{array}{l}\text { Any waste } \\
\text { other than } \\
\text { oil }\end{array}$ & $\begin{array}{l}\text { Operation of } 4-6 \text { wk/ } \\
\text { yr, hurning of TBP- } \\
\text { kerosene causes nasal } \\
\text { irritations downwind } \\
\text { of stack }\end{array}$ \\
\hline 11. & $\begin{array}{l}\text { United Nuclear Corp: } \\
\text { Wood River Junction, } \\
\text { RI }\end{array}$ & $1967-1974$ & $\begin{array}{l}\text { Production - Single chamber unit } \\
\text { with gas burner }\end{array}$ & Cyclone, scrubber system & 45.5 & Unknown & $\begin{array}{l}\text { Evidence of incomplete } \\
\text { combustion, NRC closed } \\
\text { down unit due to "pro- } \\
\text { blems in effluent con- } \\
\text { trol" }\end{array}$ \\
\hline 111. & $\begin{array}{l}\text { Goodyear Atomic Corp. } \\
\text { Piketon, } \mathrm{OH}\end{array}$ & $1971-?$ & $\begin{array}{l}\text { Production Unit - Commercial (Mark } \\
\text { VI radicator); refractory lined, } \\
\text { dual chamber with gas burner in } \\
\text { secondary chamber }\end{array}$ & $\begin{array}{l}\text { None, direct exhaust to } \\
\text { stack from secondary } \\
\text { chamber }\end{array}$ & $2270 \mathrm{~kg} / \mathrm{mo}$ & Unknown & $\begin{array}{l}\text { Batch basis operation } \\
\text { on uranium contani- } \\
\text { nated waste }\end{array}$ \\
\hline IV. & $\begin{array}{l}\text { Union Carbide Corp. } \\
\text { K-25 Plant } \\
\text { Oak Ridge, iN }\end{array}$ & $1972-?$ & $\begin{array}{l}\text { Production - Dual chamber unit; } \\
\text { primary chamber has underfire air } \\
\text { and ges burner }\end{array}$ & $\begin{array}{l}\text { None, direct exhaust to } \\
\text { stack from secondary } \\
\text { chamber }\end{array}$ & Unknown & $\begin{array}{l}\text { Rubber, } \\
\text { PVC }\end{array}$ & $\begin{array}{l}\text { Unit is cycled daily } \\
\text { from hot to cold, } \\
\text { burns uranium con- } \\
\text { taining floor swrep- } \\
\text { ings }\end{array}$ \\
\hline
\end{tabular}


RECENT UNITED STATES RADIOACTIVE WASTE INCINERATORS

\begin{tabular}{|c|c|c|c|c|c|c|c|}
\hline & LOCATION & $\begin{array}{l}\text { PERIOD OF } \\
\text { OPERATION }\end{array}$ & INCINERATOR TYPE & OFF GAS SYSTEM & $\begin{array}{l}\text { CAPACITY } \\
(\mathrm{kg} / \mathrm{hr})\end{array}$ & $\begin{array}{l}\text { COMBUSTIBLE } \\
\text { WASTES NOT } \\
\text { ACCEPTABLE }\end{array}$ & COMMENTS \\
\hline v. & $\begin{array}{l}\text { Union Carbide Corp. } \\
\text { Paducah, KY }\end{array}$ & $\begin{array}{l}\text { Unknown, re- } \\
\text { started in } \\
1976-?\end{array}$ & Unknown & Scrubber & Unknown & Unknown & $\begin{array}{l}\text { Had corrosion prob- } \\
\text { lems and poor scrub- } \\
\text { ber efficiency }\end{array}$ \\
\hline vi. & $\begin{array}{l}\text { Union Carbide Corp. } \\
\text { Y-12 Plant } \\
\text { Oak Ridge, TN }\end{array}$ & 21955-? & $\begin{array}{l}\text { Production - Single vertical } \\
\text { cylinder; refractory lined } \\
\text { with rabble arm and two gas } \\
\text { fired burners }\end{array}$ & $\begin{array}{l}\text { Heat exchanger, cyclone, } \\
\text { multi-tube dust collector, } \\
\text { air dilution, baghouse }\end{array}$ & 20 & $\begin{array}{l}\text { PVC and } \\
\text { rubber con- } \\
\text { tent are } \\
\text { controlled }\end{array}$ & $\begin{array}{l}\text { Used for highly en- } \\
\text { riched uranium waste, } \\
\text { some containment } \\
\text { problems, only one } \\
\text { baghouse fire, re- } \\
\text { fractory replaced } \\
\text { every } 2-3 \text { years }\end{array}$ \\
\hline vil. & $\begin{array}{l}\text { Gulf General Atomics } \\
\text { San Diego, CA }\end{array}$ & $\begin{array}{l}1963-1965 \\
1973-7\end{array}$ & $\begin{array}{l}\text { Production - Multi-chamber, } \\
\text { fire brick lined unit; primary } \\
\text { chamber with propane burner; } \\
\text { secondary al so with propane } \\
\text { burner; and mixing chamber } \\
\text { with additional air }\end{array}$ & $\begin{array}{l}\text { Long duct with four wire } \\
\text { mesh screens, baghouse, } \\
\text { filter unit }\end{array}$ & $\begin{array}{l}8-10 \text { bar - } \\
\text { rels per } \\
8 \mathrm{hr} \text { day }\end{array}$ & $\begin{array}{l}\text { Plastics, } \\
\text { rubber }\end{array}$ & $\begin{array}{l}\text { Used for enriched } \\
\text { uranium waste, charg } \\
\text { ing limit for U-235 } \\
\text { controls operation, } \\
\text { long duct with } \\
\text { screens was added } \\
\text { in } 1973 \text { to prevent } \\
\text { filter failures in } \\
\text { baghouse }\end{array}$ \\
\hline vill. & $\begin{array}{l}\text { General Electric } \\
\text { Nuclear Fuel Plant } \\
\text { Wilmington, NC }\end{array}$ & 1970-? & $\begin{array}{l}\text { Production - Comercial (Vortex } \\
\text { I Vorcinerator) unit; blown waste } \\
\text { is fed tangentially into fire- } \\
\text { brick cyllindrical chamber; } \\
\text { natural gas burner used to main- } \\
\text { tain temperature }\end{array}$ & $\begin{array}{l}\text { Wet spray scrubber, mist } \\
\text { eliminator, reheater, pre- } \\
\text { filter, HEPA filters }\end{array}$ & 227 & Liquids & $\begin{array}{l}\text { Problems have been - } \\
\text { shredder damage from } \\
\text { metal, cantamination } \\
\text { from pnuematically } \\
\text { conveylng waste, } \\
\text { corrosion problems } \\
\text { in scrubber } 8 \text { mist } \\
\text { elimlnator, plugged } \\
\text { filters, large } \\
\text { natural gas useage }\end{array}$ \\
\hline
\end{tabular}


RECENT UNITED STATES RADIOACTIVE WASTE INCINERATORS

\begin{tabular}{|c|c|c|c|c|c|c|c|}
\hline & LOCATION & $\begin{array}{l}\text { PERIOD OF } \\
\text { OPERATION } \\
\end{array}$ & INCINERATOR TYPE & OFF GAS SYSTEM & $\begin{array}{l}\text { CAPACITY } \\
(\mathrm{kg} / \mathrm{hr})\end{array}$ & $\begin{array}{l}\text { COMBUSTIBLE } \\
\text { WASTES NOT } \\
\text { ACCEPTABLE } \\
\end{array}$ & COMMENTS \\
\hline Ix. & $\begin{array}{l}\text { West inghouse Nuclear } \\
\text { Fuel Division } \\
\text { Columbia, SC }\end{array}$ & $1974-?$ & $\begin{array}{l}\text { Production - Dual chamber, re- } \\
\text { fractory lined unit; primary } \\
\text { and secondary chambers both } \\
\text { have burners and air inlets }\end{array}$ & $\begin{array}{l}\text { Wet spray scrubber, } \\
\text { demister, prefilters, } \\
\text { HEPA filters }\end{array}$ & Unknown & Unknown & $\begin{array}{l}\text { Used for slightly } \\
\text { enriched uranium } \\
\text { waste, problems } \\
\text { with scrubber li- } \\
\text { quid filters plug- } \\
\text { ging and high HEPA } \\
\text { use rate, oper?- } \\
\text { tion controlled } \\
\text { by U-235 limits }\end{array}$ \\
\hline$x$. & $\begin{array}{l}\text { Nuclear Fuel Services, } \\
\text { Incorporated } \\
\text { Erwin, TN }\end{array}$ & Unknown & $\begin{array}{l}\text { Production - Commercial (Com- } \\
\text { bustall by Air Preheater) unit } \\
\text { of air preheater; primary re- } \\
\text { fractory lined chamber with } \\
\text { gas burner; afterburner with } \\
\text { additional air input }\end{array}$ & $\begin{array}{l}\text { Spray prescrubber, ven- } \\
\text { turi scrubber, disengag- } \\
\text { ing tank, stack }\end{array}$ & 272 & Unknown & $\begin{array}{l}\text { Operation control- } \\
\text { led by U-235 limits }\end{array}$ \\
\hline XI. & $\begin{array}{l}\text { Kerr-McGee Nuclear } \\
\text { Corporation } \\
\text { Crescent, OK }\end{array}$ & $1972-?$ & $\begin{array}{l}\text { Production - Refractory lined, } \\
\text { dual chamber unit with two gas } \\
\text { fired burners; batch ash re- } \\
\text { moval }\end{array}$ & $\begin{array}{l}\text { Dilution air, baghouse, } \\
\text { filters }\end{array}$ & $\sim 72$ & PVC & $\begin{array}{l}\text { Operation controlled } \\
\text { by } U-235 \text { limits, low } \\
\text { combust lon tempera- } \\
\text { ture requires ash } \\
\text { treatment to remove } \\
\text { residual carbon }\end{array}$ \\
\hline$x \mid 1$ & $\begin{array}{l}\text { Los Alamos Scientific } \\
\text { Laboratory } \\
\text { Los Alamos, NM }\end{array}$ & $\begin{array}{l}1952-1959 \\
\text {-rebuilt- } \\
\text { 1959-? }\end{array}$ & $\begin{array}{l}\text { Production - Stainless steel burn } \\
\text { basket in electrically heated } \\
3 \text { l6ss tube; pure oxygen used as } \\
\text { oxidizer; batch feed and ash re- } \\
\text { moval; rebuild included parts re- } \\
\text { placement; excessive pressure re- } \\
\text { lief vent; and addition of } \\
\text { another glove box }\end{array}$ & $\begin{array}{l}\text { Water-filled bubbler, heat } \\
\text { exchanger, slight warming, } \\
\text { Nash vacuum pump, plant- } \\
\text { process alr-exhaust system }\end{array}$ & to .5 & $\begin{array}{l}\text { Plastics } 6 \\
\text { rubber } \\
\text { whenever } \\
\text { possible }\end{array}$ & $\begin{array}{l}\text { Have had one bag- } \\
\text { house fire, lesigned } \\
\text { for nlutonium re- } \\
\text { eovery from wastes, } \\
\text { some pressure excur- } \\
\text { sions from } \mathrm{HNO}_{3}+ \\
\text { rags forming nitro- } \\
\text { cellulose, otherwise } \\
\text { very few problems, } \\
\text { duplicate unlt is be } \\
\text { ing installed in new } \\
\text { Pu processing racili } \\
\text { ly }\end{array}$ \\
\hline
\end{tabular}




\begin{tabular}{|c|c|c|c|c|c|c|}
\hline LOCATION & $\begin{array}{l}\text { PERIOD OF } \\
\text { OPERATION }\end{array}$ & INCINERATOR TYPE & OFFGAS SYSTEM & $\begin{array}{l}\text { CAPACITY } \\
(\mathrm{kg} / \mathrm{hr})\end{array}$ & $\begin{array}{l}\text { COMBUSTIBLE } \\
\text { WASTES NOT } \\
\text { ACCEPTABLE }\end{array}$ & COMMENTS \\
\hline XIII. Yankee Atomic & $\begin{array}{l}\text { Late } \\
\text { 1960-7 }\end{array}$ & $\begin{array}{l}\text { Production - Single chamber with } \\
\text { vortex air flow }\end{array}$ & $\begin{array}{l}\text { Rotoclone, deep-bed glass } \\
\text { wool filter, stack }\end{array}$ & 18.2 & Plastics & $\begin{array}{l}\text { Reportedly has worked } \\
\text { well }\end{array}$ \\
\hline $\begin{array}{l}\text { XIV. Mound Laboratory } \\
\text { Miamisburg, OH }\end{array}$ & Unknown & $\begin{array}{l}\text { Essentially identical to LASL } \\
\text { unit above, XII, also for Pu } \\
\text { recovery }\end{array}$ & $\begin{array}{l}\text { Heat exchanger, bubbler } \\
\text { vessel, caustic scrubber } \\
\text { tower, mist el iminator, } \\
\text { casson filter, HEPA filter }\end{array}$ & $\begin{array}{l}\text { 20gal/ } \\
\text { day }\end{array}$ & $\begin{array}{l}\text { PVC, glove } \\
\text { box gloves }\end{array}$ & $\begin{array}{l}\text { Very few operational } \\
\text { problems }\end{array}$ \\
\hline \multirow[t]{3}{*}{$\begin{array}{l}\text { XV. Rockwell International } \\
\text { Rocky Flats, co. }\end{array}$} & 1959-7 & $\begin{array}{l}\text { Production - For Pu recovery; } \\
\text { dual chamber, firebrick lined } \\
\text { unit, supplementary oxygen is } \\
\text { used to maintain temperature }\end{array}$ & $\begin{array}{l}\text { Heat exchanger, second heat } \\
\text { exchanger, caustic spray } \\
\text { cooler, wet venturi scrubber, } \\
\text { wet cyclone, mist el iminator, } \\
\text { filters }\end{array}$ & 16 & $\begin{array}{l}\text { Potentially } \\
\text { explosive } \\
\text { materials }\end{array}$ & $\begin{array}{l}\text { Original offgas systen } \\
\text { was dry and had filter } \\
\text { fires, have salt build- } \\
\text { up problems in caustic } \\
\text { spray cooler, ash con- } \\
\text { tains } 130 \text { carbon }\end{array}$ \\
\hline & $\begin{array}{l}\text { Projected } \\
\text { for } 1982\end{array}$ & $\begin{array}{l}\text { Production - For waste contain- } \\
\text { ing } 3 \times 10^{-3} \mathrm{mg} \text { of Pu/gm of waste; } \\
\text { refractory lined, vertical cy- } \\
\text { linder with air cooled rabble } \\
\text { arms primary; refractory lined } \\
\text { afterburner; both chambers have } \\
\text { delsel fuel fired burners }\end{array}$ & $\begin{array}{l}\text { Wet venturi scrubber, gas } \\
\text { liquid separator, wet venturi } \\
\text { scrubber, gas-liquid separator, } \\
\text { four stage HEPA fllters }\end{array}$ & 68 & Liquids & $\begin{array}{l}\text { System is set up for } \\
\text { glove/remote operation, } \\
\text { ash discharge is es- } \\
\text { sentially batchwise }\end{array}$ \\
\hline & $\begin{array}{l}\text { Projected } \\
\text { for } 1982\end{array}$ & $\begin{array}{l}\text { Production - For waste containing } \\
\text { e } 3 \times 10^{-} \xi \mathrm{mg} \text { of Pu/gm. of waste; re- } \\
\text { fractory lined, rotary klln, diesel } \\
\text { fired burner primary chamber, re- } \\
\text { fractory lined afterburiler with } \\
\text { diesel-fired burner }\end{array}$ & $\begin{array}{l}\text { Essentially same as above with } \\
\text { exceptlon of borosilicate } \\
\text { Raschig rings in first separa- } \\
\text { tor and geometry changes for } \\
\text { crlticallty gafety }\end{array}$ & 41 & $\begin{array}{l}\text { Essentially } \\
\text { none }\end{array}$ & $\begin{array}{l}\text { HEPA filters, rubber } \\
\text { gloves, graphilte and } \\
\text { used resins will be } \\
\text { compaigned thru, have } \\
\text { extenslve safety and } \\
\text { backup systems }\end{array}$ \\
\hline
\end{tabular}


RECENT UNITEO STATES RADIOACTIVE WASTE INCINERATORS

\begin{tabular}{|c|c|c|c|c|c|c|c|}
\hline & LOCATION & $\begin{array}{l}\text { PERIOD OF } \\
\text { OPERATION }\end{array}$ & INCINERATOR TYPE & OFFGAS SYSTEM & $\begin{array}{l}\text { CAPACITY } \\
(\mathrm{kg} / \mathrm{hr})\end{array}$ & $\begin{array}{l}\text { COMBUSTIBLE } \\
\text { WASTES NOT } \\
\text { ACCEPTABLE } \\
\end{array}$ & COMMENTS \\
\hline XVI. & $\begin{array}{l}\text { At lantic Richfield } \\
\text { Hanford Company } \\
\text { Richland, WA }\end{array}$ & $1961-?$ & $\begin{array}{l}\text { Production - For Pu recovery; } \\
\text { high alloy semicylinder tube for } \\
\text { primary chamber connected to high } \\
\text { alloy tubular secondary with four } \\
\text { flue risers, electrically heated, } \\
\text { conveyer system moves waste thru } \\
\text { primary chamber }\end{array}$ & $\begin{array}{l}\text { Two cyclones in series, } \\
\text { quench-spray scrubber with } \\
\text { baffles, reheater, prefil- } \\
\text { ter, two stage HEPA filtra- } \\
\text { tion }\end{array}$ & 21.9 & $\begin{array}{l}\text { Leaded } \\
\text { gloves }\end{array}$ & $\begin{array}{l}\text { Had been shut down but } \\
\text { possible restart in } \\
1976 \text {, incinerator cham- } \\
\text { bers have been re- } \\
\text { placed three times due } \\
\text { to thernal and corro- } \\
\text { sion cracking, con- } \\
\text { veyor belt last } 1.6 \text { mo., } \\
\text { combustion is incom- } \\
\text { plete, flashback has } \\
\text { occured, still have } \\
\text { plugging problems }\end{array}$ \\
\hline XVII. & $\begin{array}{l}\text { Idaho National } \\
\text { Engineering Lab }\end{array}$ & $\begin{array}{l}1978-? \\
\text { Built but } \\
\text { in storage }\end{array}$ & $\begin{array}{l}\text { Production - Combustion occurs in } \\
\text { molten salt bed of } 90 \% \mathrm{Na}_{2} \mathrm{CO}_{3} \text { and } \\
10 \% \mathrm{Na}_{2} \mathrm{SO}_{4} \text {; alumina brick } \mathrm{l}_{\text {ined }} \\
\text { cylinder, waste feed by screw } \\
\text { feed and pnuematics, propane } \\
\text { burner for startup, coke added } \\
\text { for temperature control }\end{array}$ & $\begin{array}{l}\text { Mist eliminator, waster } \\
\text { cooler, baghouse, reheater, } \\
\text { HEPA filters }\end{array}$ & 50 & $\begin{array}{l}\text { Alpha } \\
\text { waste }\end{array}$ & $\begin{array}{l}\text { In-situ acid gas neutra } \\
\text { ization reduces corro- } \\
\text { sion, NaCl volatility } \\
\text { causes some particu- } \\
\text { lates in offgas, system } \\
\text { in storage due to hands } \\
\text { on/internal maintenance } \\
\text { requirements }\end{array}$ \\
\hline xVII1. & $\begin{array}{l}\text { Babcock \& Wilcox } \\
\text { Lynchburg, VA }\end{array}$ & $1972-?$ & $\begin{array}{l}\text { Production - Refractory lined } \\
\text { unit with gas fired primary } \\
\text { chamber and gas-fired after- } \\
\text { burner in the exhaust duct }\end{array}$ & $\begin{array}{l}\text { Venturi wet scrubber, } \\
\text { stack }\end{array}$ & 79.4 & Unknown & $\begin{array}{l}\text { No data available on } \\
\text { problems, operation con } \\
\text { trolled by U-235 limits }\end{array}$ \\
\hline
\end{tabular}


APPENDIX C

FOREIGN RADIOACTIVE WASTE INCINERATORS

\begin{tabular}{|c|c|c|c|c|c|c|c|}
\hline & LOCATION & $\begin{array}{l}\text { PERIOD OF } \\
\text { OPERATION }\end{array}$ & INCINERATOR TYPE & OFF GAS SYSTEM & $\begin{array}{l}\text { CAPACITY } \\
(\mathrm{kg} / \mathrm{lir})\end{array}$ & $\begin{array}{l}\text { COMBUSTIBLE } \\
\text { WASTES NOT } \\
\text { ACCEPTABLE }\end{array}$ & COMMENTS \\
\hline \multirow{5}{*}{$\begin{array}{l}\text { 1. UNI } \\
\text { A. }\end{array}$} & INITED KINGDOM & & & & & & \\
\hline & Harwell, Berkshire & $1950-1953$ & $\begin{array}{l}\text { Pilot - Vertical tube with one } \\
\text { stage combustion }\end{array}$ & $\begin{array}{l}\text { Gas cooler, scrubbing tower, } \\
\text { glass felt filter }\end{array}$ & Unknown & Unknown & \\
\hline & & $1954-50$ 's & $\begin{array}{l}\text { Pilot - Grate type with air cooled } \\
\text { walls and one stage combustion }\end{array}$ & $\begin{array}{l}\text { Fly ash settler, water spray } \\
\text { cooler, venturi scrubber, } \\
\text { cyclone, heater, three stage } \\
\text { filtration }\end{array}$ & Unknown & Unknown & \multirow{3}{*}{$\begin{array}{l}\text { Corrosion problem with } \\
\text { stainless steel incin., } \\
\text { lowered operating temp } \\
\text { but often incomplete } \\
\text { combustion and three } \\
\text { filter fires, so re- } \\
\text { placed dry system } \\
\text { with } 1954 \text { 's wet sys- } \\
\text { tem both } 1959 \text { and } 1962 \\
\text { units were operating } \\
\text { in } 1970\end{array}$} \\
\hline & & $1959-7$ & $\begin{array}{l}\text { Production - Annular, refractory } \\
\text { lined, with grates, natural gas } \\
\text { auxillary burners }\end{array}$ & $\begin{array}{l}\text { Heat exchanger, roughing } \\
\text { glass bag filters, three } \\
\text { absolute filters }\end{array}$ & $\begin{array}{l}180 \text { (design) } \\
100 \text { (opera) }\end{array}$ & Unknown & \\
\hline & & $1962-?$ & $\begin{array}{l}\text { Experimental - Two chamber; fire } \\
\text { brick lined; oil burners in both } \\
\text { chambers }\end{array}$ & $\begin{array}{l}\text { Heat exchanger, cyclone, } \\
\text { electrostatic precipitator, } \\
\text { absolute filter }\end{array}$ & To 27 & $\begin{array}{l}\text { High } \\
\text { Level } \\
\text { Wastes }\end{array}$ & \\
\hline & $\begin{array}{l}\text { Windscale, } \\
\text { Cumberland }\end{array}$ & $\begin{array}{l}1973 \text { to } \\
\text { present }\end{array}$ & $\begin{array}{l}\text { Pllot - Electrically heated, Inconel } \\
600 \text {, tubular primary chamber with } 3 \\
\text { separate vertical afterburner cham- } \\
\text { bers In serles al so electrically } \\
\text { heated }\end{array}$ & $\begin{array}{l}\text { Spray column, coolers, rough- } \\
\text { ing filter, demister, heater, } \\
\text { absolute filter }\end{array}$ & 5 & Unknown & $\begin{array}{l}\text { Corrosion of primary } \\
\text { furnace tube and off- } \\
\text { gas lines have been } \\
\text { problems, ash some- } \\
\text { times up to } 22 \% \text { carbon } \\
\text { similar to electric } \\
\text { air at SRP }\end{array}$ \\
\hline & . Bradwell & $\begin{array}{l}\text { Operated } \\
\text { in } 1967\end{array}$ & Production - Uses afterburner & Cyclone, absolute fllters & $\begin{array}{l}18,000 \\
\mathrm{~kg} / \mathrm{yr}\end{array}$ & $\begin{array}{l}\times 7.5 \mathrm{mR} / \\
\text { hr levels }\end{array}$ & \\
\hline D. & - Berleley, BNL & $\begin{array}{l}\text { Operated } \\
\text { in } 1967\end{array}$ & Production - Uses afterburner & $\begin{array}{l}\text { Water scrubbing, absolute } \\
\text { filters }\end{array}$ & $\begin{array}{l}37,000 \\
\mathrm{~kg} / \mathrm{yr}\end{array}$ & $\begin{array}{l}>15 \mathrm{mR} / \mathrm{hr} \\
\text { levels }\end{array}$ & \\
\hline & . Hunterston "A" & $\begin{array}{l}\text { Operated } \\
\text { in } 1967\end{array}$ & Production - Unknown & Unkrown & $74 \mathrm{~m}^{3} / \mathrm{yr}$ & $\begin{array}{l}>3 m C i \text { of } \\
35 \mathrm{~S}\end{array}$ & \\
\hline
\end{tabular}


COMBUSTIBLE

WASTES NOT

ACCEPTABLE

COMMENTS

\begin{tabular}{|c|c|c|c|c|c|c|c|c|}
\hline \multirow[t]{6}{*}{11.} & \multicolumn{8}{|c|}{ FRANCE } \\
\hline & A. & $\begin{array}{l}\text { Cadarache Nuclear } \\
\text { Study Center }\end{array}$ & Unknown & $\begin{array}{l}\text { Production - Primary chamber for } \\
\text { pyrolysis \& combustion; secondary } \\
\text { combustion chamber; fly ash settler } \\
\text { with soot burning }\end{array}$ & $\begin{array}{l}\text { Cooling chamber, air dilu- } \\
\text { tion to } \angle 200^{\circ} \mathrm{C} \text {, packed } \\
\text { tower scrub, heater, pre- } \\
\text { fitter, absolute filter }\end{array}$ & $\begin{array}{l}30 \text { for } \\
\text { Solids - } \\
10 \text { for } \\
\text { Liquids }\end{array}$ & $\begin{array}{l}\text { Non-TRU } \\
\text { Waste, } \\
\text { PV C when- } \\
\text { ever pos- } \\
\text { sible }\end{array}$ & $\begin{array}{l}\text { Study being made to } \\
\text { permit burning TRU } \\
\text { waste }\end{array}$ \\
\hline & B. & $\begin{array}{l}\text { Fontenay-aux-Roses } \\
\text { Center (CEN-FAR) }\end{array}$ & $1967-?$ & $\begin{array}{l}\text { Production - Very similar to } \\
\text { Cadarache }\end{array}$ & $\begin{array}{l}\text { Cooled by air dilution to } \\
2350^{\circ} \mathrm{C} \text {, further cooled to } \\
\sim 130^{\circ} \mathrm{C} \text {, glass-wool bag fil- } \\
\text { ter, asbestos absolute } \\
\text { filters }\end{array}$ & $\begin{array}{l}50 \text { for } \\
\text { Solids - } \\
15 \text { for } \\
l i q u i d s\end{array}$ & Unknown & $\begin{array}{l}\text { Have offgas corro- } \\
\text { sion problems from } \\
\text { PVC combustion }\end{array}$ \\
\hline & c. & $\begin{array}{l}\text { Strasbourg - } \\
\text { Cronenbourg, CNRS }\end{array}$ & 1970-? & $\begin{array}{l}\text { Production - Vertical primary } \\
\text { chamber with oil burner and } \\
\text { stalrstep grate for combustion } \\
\text { of plastics; secondary chamber } \\
\text { with separate oil burner; all } \\
\text { refractory lined steel. }\end{array}$ & $\begin{array}{l}\text { High temp. filter of asbes- } \\
\text { tos filled micro-expanded } \\
\text { refractory metal which allows } \\
\text { soot burnoff, air dilution to } \\
2150^{\circ} \mathrm{C} \text {, two stage absolute } \\
\text { filters }\end{array}$ & 15 & Unknown & $\begin{array}{l}\text { Primarily for con- } \\
\text { taminated animal } \\
\text { remains, can handle } \\
\text { small quantities of } \\
\text { solvents }\end{array}$ \\
\hline & \multirow[t]{2}{*}{ D. } & Marcoule & $\begin{array}{l}1964-\text { To } \\
\text { Present }\end{array}$ & $\begin{array}{l}\text { Production - Three firebrick } \\
\text { chambers; primary separated by } \\
\text { bridge-wall from secondary; ex- } \\
\text { pansion chamber; propane burners } \\
\text { In first two chambers }\end{array}$ & $\begin{array}{l}\text { Two heat exchangers to lower } \\
\text { gas to } 150^{\circ} \mathrm{C} \text {, cyclone, anti- } \\
\text { spark mat, glass-fiber bag } \\
\text { filters, prefliter, mbsolute } \\
\text { fliter, acid scrub column, } \\
\text { demister }\end{array}$ & $\begin{array}{l}60-70 \\
(\text { solids) } \\
50 \mathrm{l} / \mathrm{hr} \\
(0 / 1)\end{array}$ & $\begin{array}{l}\text { PVC when- } \\
\text { ever pos- } \\
\text { sible }\end{array}$ & $\begin{array}{l}\text { Feed is usually } \\
\text { blended stream of } \\
\text { oil and shredded } \\
\text { waste }\end{array}$ \\
\hline & & & $\begin{array}{l}1970-\text { To } \\
\text { Present }\end{array}$ & $\begin{array}{l}\text { Pilot - One piece cast refract- } \\
\text { ory in metal shell with main } \\
\text { combustion and afterburner cham- } \\
\text { bers; both electrlcally heated }\end{array}$ & $\begin{array}{l}\text { Air dilution to cool to } 300^{\circ} \mathrm{C} \text {, } \\
\text { heat exchanger cools to } 60^{\circ} \mathrm{C} \text {, } \\
\text { double absolute filters. } \mathrm{HCl} \\
\text { is not treated }\end{array}$ & 1 & $\begin{array}{l}\text { Non-Pu } \\
\text { Contamina- } \\
\text { ted waste }\end{array}$ & $\begin{array}{l}\text { Incinerator was } \\
\text { built as part of } \\
\text { plutonium recycle } \\
\text { system, screw con- } \\
\text { veyer system for } \\
\text { feed hasn't worked } \\
\text { satisfactorily }\end{array}$ \\
\hline
\end{tabular}


OMBUSTIBLE

ACCEPTABLE

COMMENTS

D. Marcoule (Continued) To Be Production - Very similar to above pilot unit

Buil

Pilot - Unknown

E. Grenoble, CEN-G

$1961-1964$
?-Present

Production - Primary combustion chamber with after burner
High temp. filter like II.B. Unkown alr dilution to cool to $2140^{\circ} \mathrm{C}$, absolute filter

A. Belgium Nuclear 1960's
Center, Mol

111. BELGIUM

\begin{abstract}
Production - Three chambers; lined Several systems tried, end with refractory brick; first chamber system had cooler, expansion for combustible wastes; second for other wastes (animal remains); third chamber, packed tower, elecas afterburner for first two; propane solute filter burners for temperature control Pilot - Tangential: propane burner to maintain temperature

Cyclone, heat exchanger, sand filter, wet cleanup system

Production - Slagging type, conical primary chamber of tamped refractory

Input air preheater, heat exafterburner with secondary alr, ash exchanger, caustic wet scrubmelts at bottom of primary and drips ber, preheater, HEPA filters, into quench tank, fuel oil-fired bur-preheater, stack ner In prlmary
\end{abstract}

$1970-7$

$1977-?$

$200(\max )$
10
100

$>200$

level

Unknown

PVC when

possible slagging unit for ash treatment

Unit was built speci-

fically to handle bio-

logical E organic waste, unit will handle solvents

Unit was built specifically to handle biological \& organic wastes unit will handle solvents

Many corrosion problems, most in of fgas system

Sand may be added to increase slagging and $\mathrm{Na}_{2} \mathrm{CO}_{3}$ to neutralize acid gases, waste must be sized to less than $5 \mathrm{~cm}$. dimension to $\mathrm{fit}$ waste feed systen, hot operation planned for 1979

IV. PORTUGAL

Sacaveln Center

Planned
25
Cyclone, dry filters plate
High level Primarily for small waste animal bodies 
FOREIGN RADIOACTIVE WASTE INCINERATORS

\begin{tabular}{|c|c|c|c|c|c|c|c|}
\hline & LOCATION & $\begin{array}{l}\text { PERIOD OF } \\
\text { OPERATION }\end{array}$ & INCINERATOR TYPE & OFF GAS SYSTEM & $\begin{array}{l}\text { CAPAC ITY } \\
(\mathrm{kg} / \mathrm{hr})\end{array}$ & $\begin{array}{l}\text { COMBUSTIBLE } \\
\text { WASTES NOT } \\
\text { ACCEPTABLE } \\
\end{array}$ & COMMENTS \\
\hline \multirow[t]{4}{*}{ v. } & REPUBLIC OF GERMANY & & & & & & \\
\hline & $\begin{array}{l}\text { A. Nuclear Research } \\
\text { Center, Karlsruhe }\end{array}$ & $1963-1970$ & $\begin{array}{l}\text { Pilot - Vertical tube; refractory } \\
\text { lined; two bottom air feeds, gra- } \\
\text { vity ash drop }\end{array}$ & $\begin{array}{l}\text { Course, sic filter which is } \\
\text { also afterburner at } 900^{\circ} \mathrm{C} \text {, } \\
\text { fine sic filter at } 600^{\circ} \mathrm{C} \text {, tar } \\
\text { separator at } 80^{\circ} \mathrm{C}\end{array}$ & Unknown & $\begin{array}{l}\text { High level } \\
\text { wastes }\end{array}$ & $\begin{array}{l}\text { Original offgas sys- } \\
\text { tem had bag filters } \\
\text { also several fires, } \\
\text { had some problems } \\
\text { with pressure sur- } \\
\text { ges }\end{array}$ \\
\hline & & $\begin{array}{l}1971 \text { To } \\
\text { Present }\end{array}$ & $\begin{array}{l}\text { Production - Similar to; but lar- } \\
\text { ger than pilot }\end{array}$ & $\begin{array}{l}\text { Similar to pilot plant, } \\
\text { except no tar separator } \\
\text { and air dilution used } \\
\text { after fine filter }\end{array}$ & $50-70$ & $\begin{array}{l}\text { Alpha } \\
\text { wastes }\end{array}$ & $\begin{array}{l}\text { Have parrallel fil- } \\
\text { ter systems, wet } \\
\text { scrubber system for } \\
\text { high levels of } \\
\text { activity in offgas }\end{array}$ \\
\hline & B. Other & Unknown & $\begin{array}{l}\text { Pilot - Electrically heated ver- } \\
\text { tical tube with precombustion } \\
\text { chamber; grate; and afterburner } \\
\text { chamber }\end{array}$ & $\begin{array}{l}\text { Cyclone, air dilution, } \\
\text { coarse filter, fine filter }\end{array}$ & 210 & $\begin{array}{l}>100 \mathrm{mCi} / \\
\mathrm{kg}\end{array}$ & $\begin{array}{l}\text { Specifically for } \\
\text { animal waste dis- } \\
\text { posal }\end{array}$ \\
\hline \multirow[t]{3}{*}{ vi. } & INDIA & & & & & & \\
\hline & $\begin{array}{l}\text { A. Bhahha Atomic } \\
\text { Research Center } \\
\text { Trombay }\end{array}$ & $1963-1966$ & $\begin{array}{l}\text { Pilot - High alumina refractory } \\
\text { vertical tube cast in one piece } \\
\text { with bottom alr feed and kerosene } \\
\text { burners }\end{array}$ & $\begin{array}{l}\text { Cooled in long, bare } \\
\text { ducts to } 200 \mathrm{c} \text {, single } \\
\text { bag fabrle fllter, as } \\
\text { bestos glass absoliute } \\
\text { filter }\end{array}$ & $\begin{array}{l}11.3 \text { (de- } \\
\text { sign) up } \\
\ln 22\end{array}$ & $\begin{array}{l}\text { All other } \\
\text { than wood }\end{array}$ & $\begin{array}{l}\text { For thorium con- } \\
\text { taminated wood waste, } \\
\text { llttle corroslon } \\
\text { even with C. steel } \\
\text { and } 3 \text { loss materials }\end{array}$ \\
\hline & & 1966-? & $\begin{array}{l}\text { Production - Two separate cham- } \\
\text { bers of refractory lined steel; } \\
\text { prlmary with underflre alr and } \\
\text { gravity ash drop; oil burners }\end{array}$ & $\begin{array}{l}\text { Cyclone, then same as } \\
\text { above pilot unit }\end{array}$ & 45 & $\begin{array}{l}>200 \mathrm{mR} / \mathrm{hr}, \\
\text { al pha } \\
\text { waste }\end{array}$ & \\
\hline
\end{tabular}


PERIOD OF

OPERATION

INC INERATOR TYPE

OFF GAS SYSTEM

CAPACITY WASTES NOT

ACCEPTABLE

COMMENTS

vII. JAPAN

A. JAERI, Tokal

1966-?

1973-7

B. Oavai Research Establishment at JAERI

1973-?

$\vec{\infty}$

\section{CANADA}

A. Chalk River Nu- 1960-1961 clear Labo Ontario

B. Douglas Point

Unknown Station, Ontario
Pilot - Unknown

Production - Upper primary combust - Spray-scrubber, cyclone, tion chamber; grate; lower second- electrostatic precipitaary chamber; refractory lined; both tor, cooler-heater unit, chambers oil fired cloth filter, HEPA filter

High temperature alumina filter $\left(800^{\circ} \mathrm{C}\right)$, secondary alumina filter

Last 2 chambers act as set- $\leadsto 30$

tling basins, 2 heat ex-

changers in series, electro-

statlc precipltator, heat

exchanger, dry fllters,

caustic wet scrubber

ner In primary; propane in sec-

ner in pr

Pilot - Refractory-insulationsteel constructlon; primary

chamber with propane burner to

malntain $815^{\circ} \mathrm{C}$; mlxing chamber

where overfire alr introduced

\& 2nd propane burner to maintain

temperature; secondary combus -

tlon chamber last

Unclassified - Open plt

None
Spark hold-up tank, air dilution to cool, glass

loth bag filters

to 250

solute filters

(250

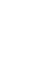

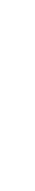

$20 \mathrm{mR} / \mathrm{hr}$

$>50 \mathrm{mR} / \mathrm{hr}$,
alpha
waste,
plastics,
rubber

Alpha

wastes

Alpha

wastes,

$>50 \mathrm{mR} / \mathrm{hr}$

(pr
some corrosion
problems in of fgas
equipment

Serlous cracking of lefractory curtain wall occured, operation found to be uneconomical

Unknown
$>26 m R / h r$
Used on nuclear power plant waste 
FOREIGN RADIOACTIVE WASTE INCINERATORS

\begin{tabular}{|c|c|c|c|c|c|c|c|}
\hline & LOCATION & $\begin{array}{l}\text { PERIOD OF } \\
\text { OPERATION }\end{array}$ & INCINERATOR TYPE & OFF GAS SYSTEM & $\begin{array}{l}\text { CAPACITY } \\
(\mathrm{kg} / \mathrm{hr})\end{array}$ & $\begin{array}{l}\text { COMBUSTIBLE } \\
\text { WASTES NOT } \\
\text { ACCEPTABLE }\end{array}$ & COMMENTS \\
\hline c. & $\begin{array}{l}\text { Bruce Nuclear } \\
\text { Complex, Ontario }\end{array}$ & $\begin{array}{l}\text { Scheduled } \\
1976 \\
\text { start }\end{array}$ & $\begin{array}{l}\text { Production - Controlled air; } \\
\text { batch loads; primary chamber } \\
\text { with gas heated afterburner }\end{array}$ & $\begin{array}{l}\text { Cooled to } 204^{\circ} \mathrm{C} \text {, bag } \\
\text { filters }\end{array}$ & Unknown & Unknown & $\begin{array}{l}\text { For disposal of nu- } \\
\text { clear generat ing } \\
\text { station waste }\end{array}$ \\
\hline D. & $\begin{array}{l}\text { Chalk River } \\
\text { Laboratory } \\
\text { Ontario }\end{array}$ & Planned & $\begin{array}{l}\text { Pilot - Similar to Bruce } \\
\text { Nuclear Complex }\end{array}$ & $\begin{array}{l}\text { Similar to Bruce } \\
\text { Nuclear Complex }\end{array}$ & Unknown & Unknown & $\begin{array}{l}\text { For filter testing, } \\
\text { will be smaller } \\
\text { than Bruce Nuclear }\end{array}$ \\
\hline
\end{tabular}

